\title{
Where Do Black Children Belong? The Politics of Race Matching in Adoption
}

\section{Citation}

Elizabeth Bartholet, Where Do Black Children Belong? The Politics of Race Matching in Adoption, 139 U. Pa. L. Rev. 1163 (1991).

\section{Published Version}

http://scholarship.law.upenn.edu/penn_law_review/vol139/iss5/1/

\section{Permanent link}

http://nrs.harvard.edu/urn-3:HUL.InstRepos:12965061

\section{Terms of Use}

This article was downloaded from Harvard University's DASH repository, and is made available under the terms and conditions applicable to Other Posted Material, as set forth at http:// nrs.harvard.edu/urn-3:HUL.InstRepos:dash.current.terms-of-use\#LAA

\section{Share Your Story}

The Harvard community has made this article openly available.

Please share how this access benefits you. Submit a story.

Accessibility 


\title{
University of Pennsylvania \\ Law Review
}

FOUNDED 1852

Formerly

American Law Register

VoL. 139

MAY 1991

No. 5

\section{ARTICLES}

\section{WHERE DO BLACK CHILDREN BELONG? THE POLITICS OF RACE MATCHING IN ADOPTION}

\author{
ELIZABETH BARTHOLET $\dagger$
}

TABLE OF CONTENTS

I. EARLY Fragments From ONE TRANSRACIAL ADOPTION STORY . . . . . . . . . . . . . . . . . . . 1164

† Professor of Law, Harvard Law School.

I am grateful to the many family members, friends, and colleagues who gave generously of their time reading and commenting on previous drafts. Special thanks go to: Anita Allen, Laura Armand, Robert Bennett, David Chambers, Nancy Dowd, Derek DuBois, Gerald Frug, Mary Joe Frug, Joan Hollinger, Michael Meltsner, Frank Michelman, Martha Minow, Robert Mnookin, Alan Stone, Deborah Stone, Gerald Torres, Harriet Trop, and Ciba Vaughan. I am also indebted to those professionals and scholars in the adoption field whose names are listed infra note 50, who helped illuminate for me the nature of current racial matching policies and their impact on children.

An abbreviated version of this Article will appear in a chapter of a forthcoming book by the author on adoption, reproductive technology, and surrogacy, with the working title of Children By Choice, to be published by Houghton Mifflin. 
II. THE HISTORY $\ldots \ldots \ldots \ldots \ldots \ldots \ldots \ldots \ldots \ldots \ldots$

III. Current Racial Matching Policies $\ldots \ldots \ldots \ldots \ldots 1183$

A. A Picture of the Matching Process at Work ........ 1186

B. The Proverbial Tip of the Iceberg-Of Written Rules and Documented Cases . . . . . . . . . . . . 1189

1. Laws, Regulations, and Policy Guidelines

Mandating Consideration of Race in the

Placement Decision ................ 1189

2. Cases Documenting the Removal of Black

Children from White Foster Families to

Prevent Transracial Adoption ............ 1191

C. Key Features of the Matching System . . . . . . . . 1193

1. Holding Policies . . . . . . . . . . . . 1193

2. Recruitment . . . . . . . . . . . . 1196

3. Subsidies . . . . . . . . . . . . . 1198

4. Differential Criteria for Assessing Parental Fitness 1199

IV. The IMpact of Current Policies $\ldots \ldots \ldots \ldots \ldots 1201$

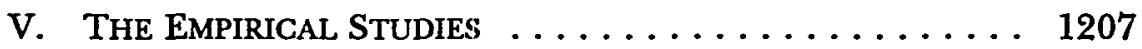

A. The Evidence as to General Adjustment . . . . . . . 1211

B. The Evidence as to Racial Attitudes .......... 1216

C. The Evidence as to Advantages for Children of

Transracial Placement ................. 1221

D. The Evidence as to Costs for Children of Current

Inrace Placement Prefierences . . . . . . . . . . . . 1223

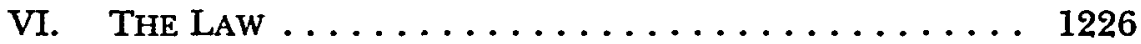

VII. DIRECTIONS FOR THE ISUTURE $\ldots \ldots \ldots \ldots \ldots \ldots \ldots$

VIII. Conclusion $\ldots \ldots \ldots \ldots \ldots \ldots \ldots \ldots \ldots \ldots$

I. Early Fragments From One TransRacial Adoption Story ${ }^{1}$

When I first walked into the world of adoption, I was stunned at the dominant role race played. I had thought I understood something about the meaning of race in our society. My life's work as a lawyer had largely involved dealing with issues of racial discrimination. But I discovered that race played a unique role in

${ }^{1}$ I use the terms "racial" and "race" in this Article to refer broadly to concepts of race, color, ethnic, and cultural difference. The focus of discussion is on adoption 
this adoption world. It was central to many people's thinking about parenting. And it was a central organizing principle for the agencies which had been delegated authority to construct adoptive families.

As a single parent of one child from an early marriage, I had decided that I wanted more children, and that I wanted to adopt. My particular adoption journey took me through the process of considering adoption in this country and abroad. I settled on a South American adoption, and had decided at one point to adopt from Brazil, but the Brazilian program closed down just as I reached the top of the list. I had long had thoughts about adopting from Peru, sparked by stories from a childhood friend of visits to the "lost city of the Incas." But I had been discouraged by the difficulties of a Peruvian adoption. Nonetheless, when Brazil fell through I picked up the telephone and called a lawyer in Lima, Peru. "Come, I have the baby for you." A week later I was in Lima, and that same day I took my first adopted child, Christopher, home to my temporary apartment in Lima. Two and one-half years later I returned to adopt Michael.

Early in the process of exploring how I might adopt, I discovered that the first order of business for the agencies responsible for matching children waiting for homes with prospective parents is to sort and allocate by race. The public and most of the traditional private adoption agencies ${ }^{2}$ would not consider assigning a waiting minority child to me, a white person, except as a last resort, and perhaps not even then. The organizations and individual entrepreneurs that arrange independent adoptions, ${ }^{3}$ while more willing to place across racial lines, also sorted children by race. In this part of the adoption world, minority children might actually be easier for the white prospective parent to find than a white child, and they were often available for a lesser fee. Information sheets listing

agency policies that mandate or promote the placement of African American children with same-race adoptive parents and oppose their placement with white adoptive parents. My personal adoption story involves the adoption of children from Peru whose color and ethnic background raise some similar issues. But by telling a piece of it I do not mean to imply that the issues are identical. A chapter discussing issues specific to international adoption will be contained in the book referred to supra note t. See also Bartholet, International Adoption: Overview, in ADOPTION LAW AND PRACTICE 10-1 to 10-44 (J. Hollinger ed. 1988).

2 For a definition of these terms, see infra notes 51-52.

${ }^{3}$ For a definition of this term, see infra note 54 . 
different prices for the different race children were handed out at counselling sessions for prospective adoptive parents.

I discovered also how dominant race was in the thinking of many prospective adoptive parents. The large majority of the people actively looking to adopt in this country are white ${ }^{4}$ and for the most part they want white children, at least initially.

The familiar refrain that there are no children available for adoption is a reflection of the racial policies of many adoption agencies and the racial preferences of many adoptive parents. The reality is that there are very few white children by comparison to the large pool of would-be white adopters. ${ }^{5}$ But there are many nonwhite children available to this pool, both through independent adoption in this country and through international adoption. ${ }^{6}$ And there are many non-white children waiting in foster care who are unavailable solely because of adoption agency insistence that they not be placed transracially. ${ }^{7}$

${ }^{4}$ There are no good statistics available on the total numbers or the racial breakdown of those seeking to adopt. There is very general agreement, however, that the large majority of those actively interested in or seeking to adopt are white, based partly on observation by those in the field and partly on basic demographics. Whites represent a significant majority of the general population and are disproportionately privileged in socioeconomic terms as compared to blacks. Those who have actively pursued adoptive parenthood have generally been people in relatively stable economic situations.

The limited statistics available that give an ethnic breakdown of those who have adopted show that of all non-relative adoptions, which are the focus of this Article, the overwhelming majority (93\%) involved white adoptive mothers. See C. BACHRACH, P. ADAMS, S. SAMBRANO \& K. LONDON, ADOPTION IN THE 1980's, ADVANCE DATA 6 (1990) [hereinafter ADOPTION IN THE 1980's]. Whites adopted at a substantially higher rate than blacks $(1.4 \%$ versus $0.8 \%)$ in non-relative adoptions and at a somewhat higher rate when all adoptions are considered. See id. at 3. Blacks, however, adopted relatives at a higher rate than whites. See id.

${ }^{5}$ Estimates as to the total numbers of those actively interested in adopting range enormously, with many arguing that the figure is one million or more. See NATIONAL COMMITTEE FOR ADOPTION, ADOPTION FACTBOOK 157.59 (1989) [hereinafter ADOPTION FACTBOOK]. A recent survey indicates that only 200,000 women are currently taking steps to pursue adoption, while two million have pursued it at some time. See C. Bachrach, K. London \& P. Maza, Path to Adoption: Adoption Seeking in the U.S. (1988) (unpublished manuscript on file with author); New Study Challenges Estimates on Odds of Adopting a Child, N.Y. Times, Dec. 10, 1990, at B10, col. 1. The figure of 200,000, however, undoubtedly constitutes a significant underestimate of those interested in adoption. It fails to account for women who have been discouraged because they believed children were not available or because of the lengthy and costly process involved in adopting. See ADOPTION IN THE 1980's, supra note 4 , at 9 .

${ }^{6}$ See Bartholet, supra note 1, at 10-14 to 10-16.

${ }^{7}$ See infra Part III. 
Racial thinking dominates the world of international adoption as well. When I began to explore the possibility of adopting from South America I was intrigued by my agency's Brazilian adoption program. Brazil allowed singles to adopt and allowed people my age to adopt infants. Babies were available for placement immediately upon birth. I would only have to spend a week to ten days there to complete the legal procedures and could then return to the United States with my baby. And there was no waiting list. I could expect to have my baby within a few months of the completion of my home study. Given the difficulties that a forty-five year old single person faces adopting from other countries, this all seemed unbelievable. The explanation was of course race. Brazil had a significant slave trade in earlier years and as a consequence much of its population is of African descent. The children available for adoption from this Brazilian program were part black. This put the program low on the desirability list for many prospective parents despite all its attractive features. Chile, by contrast, is considered a highly desirable country because it has such a white population. There are sufficiently few dark-skinned minorities that even the children of the poor-the children likely to be available for adoption-tend to be white. The Latin American countries with significant indian or mestizo but limited black populations generally fall between Chile and Brazil on the desirability list because the adoption "market" rates indian as lower than white but higher than black.

I discovered during my two adoption trips to Peru something about how children may be rated in racial terms in their own country as well as here. Most of the children available for adoption in Peru are of mixed indian and spanish heritage. But there is tremendous variety in ethnic features and skin color. For my second adoption I was offered by the government adoption agency an unusually white, one-month-old baby. My initial reaction upon meeting him was disappointment that he did not look like my first child from Peru. Christopher's brown-skinned face with its indian features had become the quintessence of what a child-my childshould look like. But I decided that it was foolish to look for another baby-Christopher, as I had decided years earlier that it would be foolish to look in adoption for a clone of my biological son. I took this baby home and named him Michael. Within twenty-four hours I found myself tearing through the streets in a taxi, mopping his feverish body with a wet cloth, and terrified, as I saw his eyes lose contact with mine and begin to stare off into the 
middle distance, that he would die in my arms before we got to the hospital emergency room. At the hospital he was wrapped entirely in a wet towel, and his feet were placed in a pan of ice water. I watched the puzzled but surprisingly cheerful little face that peered out from the monkish hood the towel formed about his head, while we waited for two hours as the temperature slowly came down. Sometime during that taxi ride, or in that hospital room, I became hopelessly attached.

Several weeks later I sat with a blanketed Michael in my arms in the office of one of Lima's fanciest pediatricians. Michael had recovered from the fever but had been suffering from nausea and diarrhea almost ever since. He had been living on a water and mineral mixture a large part of this time-it protected him from dehydration but provided no nutrition. He had kept no milk down for the last five days. I had been to three different doctors in three weeks; none seemed to have any idea what to do. They told me that babies were always sick in the summer in Lima. It was the water. They also told me that babies died all the time in Lima, as if to say that if that was what was going to happen there was really nothing that could be done and I should not get hysterical as if it was such a big deal. I told this new doctor the story of Michael's troubles, trying with my words and tone to convey my sense of desperationto make him understand that if he didn't help us Michael might die. The doctor sat impassively, interrupting me only when my threeyear-old Christopher wandered over to the bookshelves. Pointing with apparent disgust, as if some small and dirty animal had invaded his office, the doctor asked, "What is he?" I thought the question truly peculiar and the answer rather obvious, but explained that this was my son (perhaps he thought it was the child of the Peruvian nanny who was with me?). At the end of my story the doctor, who had still made no move to look at Michael, assured himself that the nanny spoke no English, and he then proceeded to tell me that he could get me another child, in a way that would avoid all the troublesome procedures of a Peruvian adoption. Women were giving birth in his hospital all the time who would not keep their babies. He could have the birth certificate for one of these babies made out showing me as the mother and the baby would be mine.

When I finally realized that this hospital baby was being suggested as a substitute for the one on my lap, I said in what I hoped was a polite but firm tone that I planned to keep this child and that I was here because I was afraid the child was seriously ill. 
I asked if the doctor could please now examine the child. He then shrugged his shoulders and showed me into the examining room.

I put Michael on the table and started to undress him, and for the first time the doctor looked at him. "Oh. I see. I understand. What an extraordinary child." He gave me what was meant to be a knowing look and kept exclaiming his surprise as he continued Michael's physical. "Entirely white. Not even any Mongolian spots..." (the spots that non-white children often have on their backsides in early life). It was overwhelmingly clear that Michael's value had been transformed in the doctor's eyes by his whiteness. Whiteness made it comprehensible that someone would want to cure and keep this child rather than discard him.

Michael got well (although with no help from this particular doctor), and turned out to have nothing more serious than an allergy to cow's milk. But his whiteness proved troubling for the rest of our stay in Lima. I was told by advisers wise in the ways of Peruvian adoptions that his unusual whiteness made him so desirable that I would have to guard against losing him to other adoptive parents, or to lawyers hungry for the high fees that he would bring. I was advised not to take him out in Lima but to keep him hidden in my apartment so that his whiteness would not become widely known. When required to take him to the various police and medical examinations and court appearances that are part of the adoption process in Lima, I learned to keep his face covered with a blanket at all times. When dealing with people who had seen him, or might know what he looked like, I would talk constantly of how frail and ill he had been since birth, hoping thereby to discount his white value.

I learned more about my own feelings about race as I puzzled through the process of creating my adoptive family. Adoption compels this kind of learning. You don't just get at the end of one general child line when you're doing adoption. There are a lot of lines, each identified by the race, disabilities, and age of the children available, together with the length of wait and the difficulty and cost of adoption. In choosing which line to join, I had to think about race, and to think on a level that was new to me. I had to try to confront without distortion the reality of parenting someone of another race-since the child and I would have to live that reality. I had to decide whether I wanted a child who was a racial look-alike or not. I had to think about whether it would be racist to look for a same-race child or racist to look for a child of another race, as I was learning that the black social workers' organization opposed 
transracial adoption, calling it a form of racial genocide. When I decided to do an international adoption I had to choose which country's line to stand in, and a piece of that choice was thinking whether I had particularly positive-or negative-feelings about the prospect of parenting a child of one of the different racial or ethnic groups involved, and musing about whether it was offensive or entirely all right to be engaged in this kind of thinking.

And then when I finally did adopt I began life as part of a Peruvian-American family, part of a brown-skin/white-skin, indiancaucasian mix of a family.

On my return with Christopher from my first Peruvian adoption, we emerge from the airplane in New York City to make our way through customs and immigration. There are signs directing "United States Citizens" to one line and "Aliens" to another. I start toward the U.S. Citizens line conscious of the comfort of finally being back in the land where I belong and then realize that since the child I am carrying is a legal alien, he and I belong in that other line, the one for those who don't belong.

When we have been back in the States for a few weeks I find myself startled on a trip to the supermarket by a stranger's question-"Where did he come from?" I'm genuinely puzzled as to why this person would think that Christopher came from some place other than me-as to why adoption would be immediately assumed. It is as if I have to be educated to see how blatant are the physical differences that others see--his brown skin, black eyes, and straight thick black hair, and my fair skin, blue eyes, and frizzy blondebrown hair. As I push Christopher through the streets in his stroller, I am struck by the appearance of other people's childrenthey are pale, anemic-looking creatures, with strangely bald heads. The brown-skinned beauty who splashes in my bathtub every night has become the norm of child.

As the months go by I begin to hear troubling comments. "Oh, he's from Peru. I didn't know they came that dark there . . . But he really seems to be doing very nicely." I realize that I need to develop responses for the things people will say to him and in his presence. I worry at the preponderance of blue-eyed, white-skinned children at his child care center and wonder what I can do about it. I listen with new ears to a familiar discussion of affirmative actionthis one by members of the child care center's parent body. I hear 
the proponents of affirmative action argue that there should be at least one minority child in each class, talking of how the other children will benefit from the minority child's presence, and I am newly angry at the blindness to the minority child's needs, and also at the tone of condescension. I attend minority parent support group meetings and learn something of the problems that the children of color face as they advance into the older grades at the local school that my biological child had attended, where I am planning to send Christopher.

And then one day, when he is three and one-half, Christopher says to me across the kitchen table at dinner, "I wish you looked like me." I respond wanting not to understand him, "What do you mean?" And he says, "I wish you were the same color." I try to reassure him, telling him that it makes no difference to me that he and I look different-in fact I like it that way. But my comments seem not to the point. He repeats that he wishes I looked like him, and his voice and eyes reveal his pain.

I am left to puzzle at the meaning of this pain. Is it one of a thousand pains that a child will experience as he discovers differences between himself and others-here a difference between himself and his school friends with their same-race parents? Is it, as the opponents of transracial adoption would have us believe, a piece of a permanent anguish at the sense that he does not truly belong in the place where he should most surely belong-his family? Or should I simply take it as a signal that living as part of a multiracial, multi-ethnic, multi-cultural family will force us to confront the meaning of racial and other differences on a regular basis?

This child is as inside my skin as any child could be. It feels entirely right that he should be there. Yet the powers that be in today's adoption world proclaim with near unanimity that racemixing in the context of adoption should be avoided if at all possible, at least where black or brown-skinned American children are involved.

This Article will look at the phenomenon of racial matching in adoption. In Part II I trace the historical development of today's matching policies, from the laws and practices of our segregationist past that systematically prohibited transracial adoption, through the period in the integrationist sixties when the barriers to such adoption were lowered, to the attack on transracial adoption made by black social workers during the heyday of the black nationalist movement. In Part III I examine the nature of today's matching policies, regarding which there is a significant conspiracy of silence. 
I discuss the written and unwritten rules requiring that minority children be held in foster care for an appropriate same-race family rather than placed immediately for adoption with waiting white families. I describe the ways in which subsidies, recruitment, and the parental screening process are used to promote inracial placement and prevent transracial placement. In Part IV I examine the evidence as to the impact of these policies on children. I note that large numbers of minority children who could be placed for adoption with waiting white families spend months or years waiting in foster care for a same-race placement. Some will "wait" for their entire childhood. In Part V I examine the empirical evidence regarding the alleged risks in transracial placement. I conclude that, contrary to many claims about the evidence, existing studies indicate that those children who have been placed transracially are flourishing. In Part VI I examine the law on racial discrimination, and question how current racial matching policies in the adoption context can be squared with the anti-discrimination norm that governs elsewhere in our social lives. And in Part VII I address the issue of what our policies should be in the future. I contend that current policies are inconsistent with the oft-proclaimed principle that the "best interests of the child" should be determinative, and that they are inconsistent with an appropriate understanding of the role race should play in social ordering.

Throughout the Article I explore the meaning of these racial matching policies-why it is that they seem to have made so much sense to so many people over the years-why it is that blacks and whites, conservatives and liberals and radicals, judges and legislators and social workers have found common cause in preventing the mixing of the races in this adoption context. I argue that these policies should not be seen as any form of "affirmative action." They cannot be understcod as an example of white majority deference to the needs and wishes of black minority groups to advance their interests or to control their destinies and perpetuate their cultures.

My thesis is that current racial matching policies represent a coming together of powerful and related ideologies-old-fashioned white racism, modern-day black nationalism, and what I will call "biologism"-the idea that what is "natural" in the context of the biological family is what is normal and desirable in the context of adoption. Biological families have same-race parents and children. ${ }^{8}$

${ }^{8}$ Even the child of a black-white intermarriage is a partial racial match with each 
The laws and policies surrounding adoption in this country have generally structured adoption in imitation of biology, giving the adopted child a new birth certificate as if the child had been born to the adoptive parents, sealing off the birth parents as if they had never existed, and attempting to match adoptive parents and children with respect to looks, intellect, and religion. The implicit goal has been to create an adoptive family which will resemble as much as possible "the real thing"-the "natural" or biological family that it is not. ${ }^{9}$ These laws and policies reflect, I believe, widespread and powerful feelings that parent-child relationships can only work, or at least will work best, between biologic likes. They also reflect widespread and powerful fears that parents will not be able to truly love and nurture biologic unlikes. These feelings and fears have much in common with the feelings and fears among both blacks and whites in our society about the dangers of crossing racial boundaries. It is thus understandable that there would be so much support for racial matching in the adoption context.

But the question is whether we should be so reluctant to cross boundaries of racial "otherness" in the context of adoption-whether today's powerful racial matching policies make sense from the viewpoint of either the minority children involved or the larger society. It is a question of growing practical importance today. Minority children are pouring, in increasing numbers, into the already overburdened foster care system, ${ }^{10}$ and current policies

of its parents. It is significant, in this context, that such transracial adoption as has taken place in our society has generally involved "black" children who have in fact a mixed black-white heritage-children who look biracial and who often have one white as well as one black biological parent. See infra note 14. These biracial children can be seen as at least a partial racial match with their white adoptive parents.

${ }^{9}$ In the forthcoming book referred to supra note $f$, I describe and critique this way of structuring adoption, arguing that we should instead recognize and celebrate the ways in which adoption is different from biological parenting and structure our laws and policies in ways that would affirm adoption's positive potential as a family form.

${ }^{10}$ Unfortunately there are no really good figures available. The federal government stopped gathering statistics on a uniform, national basis in the mid1970s. The United States National Center for Social Statistics issued its last report on adoption in 1975. See Hollinger, Introduction to Adoption Law and Practice, in ADOPTION LAW AND PRACTICE 1-52 (J. Hollinger ed. 1988). However, in recent years the federal government has begun to maintain national statistics on adoption, based on information collected on a voluntary basis from state substitute care systems. Dr. Toshio Tatara, Director of the Research and Demonstration Department of the American Public Welfare Association (APWA) heads this "Voluntary Cooperative Information Systems" (VCIS) effort. His statistics indicate that the number of children in "out-of-home placement" has increased from a total of 262,000 in 1982 
stand in the way of placing these children with available adoptive families. In addition, how we deal with the race matching issue will affect how we deal with the related issues of matching parents and children on the basis of ethnic and national background. It will therefore affect our thinking about the growing phenomenon of international adoption, which involves the adoption by whites in this country of many dark-skinned children from foreign countries and cultures. Racial matching policies also pose a question of powerful symbolic importance. How we deal with race in the intimate context of the family says a lot about how we think about and deal with race in every other context of our social lives.

\section{THE HISTORY ${ }^{11}$}

The controversy over transracial adoption that has arisen in recent decades has primarily involved the placement of children

to 280,000 in 1986 to 360,000 in 1989 , with the percentage of black children in such placement rising from $34.2 \%$ in 1982 to $34.9 \%$ in 1986 to $37.1 \%$ in 1987 . See Telephone interview with Dr. Toshio Tatara, Director of Research and Demonstration Department, American Public Welfare Association (Jan. 29, 1991) [hereinafter Tatara Interview].

Other estimates generally show that roughly half of the children in out-of-home placement are children of color, with a somewhat smaller percentage being children characterized as black. See SELEct COMM. ON CHILDREN, YOUTH, AND FAMILIES, No Place To CALl HOME: DisCaRded CHILDREN IN AMERICA, H.R. REP. No. 395, 101st Cong., 2d Sess. 5, 38 (1990) [hereinafter NO PLACE TO CALL HOME] (noting that "[i]n 1985 , minority children comprised $41 \%$ of the children in foster care," more than twice the proportion of minority children in the nation's total child population); J. MUNNS \& J. COPENHAVER, THE STATE OF ADOPTION IN AMERICA 3-4 (1989).

Most adoption professionals believe there has been an enormous increase in children coming into foster care in the last few years, with young minority children representing a large part of the increase. In No PLACE TO CALL HOME, supra, the Select Committee on Children, Youth, and Families of the United States House of Representatives estimates that if current trends continue the out-of-home placement population will increase $68 \%$ by 1995 , rising from a figure of 500,000 to 840,000 . See id. at 5 . These figures include children under the jurisdiction of juvenile correctional and mental health authorities, who are not included in the APWA statistics. Among the reasons named for this rise are increases in drug and alcohol abuse, other deteriorating social conditions, and inadequacies in social services provided. See Telephone interview with Eileen Pastorz, Director of the Adoption Subcommittee of the Child Welfare League (Jan. 28, 1991); see also Waiting For a Home, Boston Globe, Nov. 30, 1989, at 1 , col. 1 (discussing policies opposing transracial adoption in context of escalating numbers of black children in foster care); New York Sees Rise in Babies Hurt by Drugs, N.Y. Times, Oct. 18, 1989, at B1, col. 5, B2, col. 4 (discussing the reasons why the number of infants in need of special services has increased).

11 Throughout this section I rely on my review of the literature and the interviews discussed infra note 50 . In addition, I rely on the treatment of the historical development of racial matching policies, and of transracial adoption, contained in the 
generally identified as black with white families. With rare exceptions, white children have not been placed with non-whites. ${ }^{12}$ This is in part because there are many more white prospective parents waiting to adopt than there are white children waiting for adoptive homes, while there are many more black children waiting to be adopted than can be placed with black families. ${ }^{13}$ But it seems extremely likely that in addition there has been and would be at the present time enormous resistance to the prospect of placing white children with non-white families. The fact that transracial adoption, to the degree that it has occurred, has been essentially a one-way phenomenon is a central fact in the history and the politics of the issue.

A related but less publicized controversy has arisen over the placement of Native American children with white families. There has been less vocal opposition to date to the adoption by whites of children from Hispanic or other minority groups born in this country. Nor have minority leaders expressed much concern about the adoption by whites of children of color and of varied ethnic and cultural origins born in other countries and brought here as part of the growing phenomenon of international adoption.

This Article focuses on the policies that make race a central factor in determining placement for black as well as for white children born in this country. The tradition in the adoption world has been to categorize as "black" all children and prospective parents with any identifiable black African heritage and to place all such children with black parents. The label "transracial" has been applied to any adoption involving placement with white parents of a biracial child, or indeed of any child having any identifiable black heritage. ${ }^{14}$ Although I find the terminology problematic, I will use

following: D. DAY, THE ADOPTION OF BLACK CHILDREN: COUNTERACTING INSTITUTIONAL DISCRIMINATION (1979); Macaulay \& Macaulay, Adoption for Black Children: A Case Study of Expert Discretion, in 1 RESEARCH IN LAw AND SOcIOLOGY 265 (R. Simon ed. 1978); R. Simon \& H. AltsteIn, TRANSRAcIal ADOPTEES AND THEIR FAMILIES (1987) [hereinafter R. SIMON \& H. ALTSTEIN, TRANSRACIAL ADOPTEES]; R. SimON \& H. AltSTEIN, TRANSRAGIAL ADOPTION: A Follow Up (1981) [hereinafter R. Simon \& H. AltSTein, TRANSRACIAL AdOption II]; and R. SIMON \& H. AltSTEIN, TrANSRAGIAL AdOPTION (1977) [hereinafter R. SimON \& H. AltSTEIN, TRANSRAGIAL ADOPTION I].

12 One student of transracial adoption states that in all her research, she came across a total of four agency placements of white children with black families. See D. DAY, supra note 11 , at 99.

13 See infra notes $61-62$ and accompanying text.

14 Most transracial adoptions have involved children who are in fact biracial or multiracial and relatively light rather than dark-skinned. See D. DAY, supra note 11, 
the terms "black" and "transracial" in this Article in the way they generally have been used in this context.

Through the middle of this century there were near-absolute barriers to transracial adoption posed by adoption agency practice, by social attitudes, and by the law. As adoption agencies gained increasing power in the late nineteenth and early twentieth centuries to screen prospective parents and to assign waiting children to particular homes, they helped to institutionalize the racial barriers. Agencies adopted a powerful "matching" philosophy. Prospective parents were ideally to be matched with children who were physically and mentally as close a match as possible to the biological children they might have produced. This kind of matching was thought to maximize the chances for a successful bonding and nurturing relationship between parent and child. The underlying assumption was that the parent-child relationship would be threatened by differences. Race was accepted without question in the early days as one of the features to be matched. And racial matching remained as a central governing principle long after the agencies surrendered other aspects of their matching philosophy. ${ }^{15}$

In the larger society segregation was the order of the day in much of the country, and supporters of that order saw the mixing of the races in the intimate context of the family as the ultimate symbol of the outrage and degradation threatened by moves toward a more integrated society. "Race mixer" was the epithet hurled at people like myself who worked in the South in the early 1960s to break down legal barriers to integration.

The law reflected the primal importance to a segregated society of maintaining racial separation in the context of the family. Most states prohibited interracial marriage at some point in their

at 94 (noting that transracial adoptees are "almost always" biracial, with one white biological parent). The theory has been that these kinds of placements constitute less of a breach with same-race matching principles than would placement of the "pure" black child with white parents.

${ }^{15}$ The 1958 Standards for Adoption Service of the Child Welfare League of America reflected the importance of racial matching to the adoption professionals. See CHILD WELFARE LEAgUe OF AMERICA, STANDARDS FOR ADOPTION SERVICE (1958). These standards provided that " [p] hysical resemblances should not be a determining factor in the selection of a home, with the possible exception of such racial characteristics as color." Id. $\$ 4.11$. The rationale given was that "children placed in adoptive families with similar racial characteristics, such as color, can become more easily integrated into the average family group and community." Id. \$4.6. See also Macaulay \& Macaulay, supra note 11, at 280-84 (discussing the adoption professionals' role in the nature and development of racial matching policies over the years). 
history. ${ }^{16}$ The Supreme Court of the United States did not rule such laws unconstitutional until $1967,{ }^{17}$ thirteen years after it held segregation in the context of public school systems unconstitutional. ${ }^{18}$ Some state laws similarly prohibited transracial adoption. ${ }^{19}$ In the early 1960s, South Carolina's laws provided that no one could adopt the child of one white and one black parent. ${ }^{20}$

Judicial opinions in the 1950 s and early 1960s reflect some common attitudes of the time. In one case an adoption court denied a black man's petition to adopt his white step-child, reasoning as follows: "The boy when he grows up might lose the social status of a white man by reason of the fact that by record his father will be a negro ...."21 In another case a transracial adoption was initially denied with this justification: "The good Lord created five races and if he intended to have only one, he would have done so. It was never intended that the races should be mixed." 22 While both these cases were reversed on appeal, the

${ }^{16}$ See, e.g., Loving v. Virginia, 388 U.S. 1, 6 n.5 (1967) (identifying thirty states that had anti-miscegenation laws at that or some previous time).

${ }^{17}$ See id. at 2. At the time 16 states still prohibited interracial marriage. See id. at 6 \& n.5; Perry, Race and Child Placement: The Best Interests Test and the Cost of Discretion, 29 J. FAM. L. 51, 80-81 (1990).

${ }^{18}$ See Brown v. Board of Educ., 347 U.S. 483 (1954).

19 See LA. Rev. Stat. ANN § 9.422 (West 1965); TEX. Rev. Civ. Stat. ANN. arts. $46 \mathrm{a}(8), 46 \mathrm{~b}-1(4)$ (Vernon 1959). These laws were ruled unconstitutional in Compos v. McKeithen, 341 F. Supp. 264 (E.D. La. 1972) and In re Gomez, 424 S.W.2d 656 (Tex. Civ. App. 1967), respectively. See also Grossman, A Child of a Different Color: Race as a Factor in Adoption and Custody Proceedings, 17 BUFFALO L. REv. 303, 307-09 (1968).

In addition, some states allowed adoptive parents to annul an adoption and return the child if, as the years went by, the child turned out to be of a different racial ancestry than the parents. See KY. REV. STAT. ANN. \$ 199.540(1) (Michie 1982 \&c Supp. 1990); MO. ANN. STAT. \$ 453.130 (Vernon 1952) (repealed 1982). Indeed, Kentucky's law has yet to be repealed.

There was an obvious linkage between these statutes and the anti-miscegenation statutes. For example, the Missouri statute provided that the adoption of a child who proved to be of a race whose members were prohibited by law from marrying could be annulled. See id.; see also S.C. CoDE ANN. § 10-2585 (Law. Co-op. 1962) (repealed 1964); Note, Adoption in South Carolina, 9 S.C.L.Q. 210,212 n.16 (1957). Virginia law once provided that a white woman who gave birth to a brown-skinned child would immediately lose the child, who would then be indentured. See D. DAY, supra note 11 , at 89.

20 See S.C. CODE ANN. § 10-2585 (Law. Co-op. 1962) (repealed 1964).

${ }^{21}$ In re Adoption of a Minor, 228 F.2d 446, 447 (D.C. Cir. 1955) (quoting and reversing unpublished memorandum opinion of District Court of Columbia).

22 This statement is reported in MARRIAGE ACROSS THE COLOR LINE 67 (C. Larrson ed. 1965). The case reversing this unreported decision by the Ohio Probate Court is In re Baker, 117 Ohio App. 26, 185 N.E.2d 51 (1962). 
highest court of the state of Washington reasoned in 1950, in a case involving the related issue of a custody dispute between a black father and a white mother, that custody was appropriately awarded to the father on the following grounds: "These unfortunate girls, through no fault of their own, are the victims of a mixed marriage and a broken home. They will have a much better opportunity to take their rightful place in society if they are brought up among their own people. ${ }^{23}$

The 1960s represented a period of relative openness to transracial adoption. Foreign adoptions helped pave the way. ${ }^{24}$ In the aftermath of the Korean War, South Korea made many of its abandoned and orphaned children available for adoption. Large numbers of these were mixed race children who had been fathered by black American soldiers stationed in Korea. Adoption agencies and prospective parents looked increasingly to Korea and to Third World countries in a trend that has continued to this day. The children they brought here for adoption, many of whom had identifiably foreign features and dark skin, began to accustom people to the idea of adoptive families that involved a mix of racial and ethnic backgrounds. The civil rights movement in this country brought increasing attention to the plight of the minority children who had languished in the foster care systems over the years. This movement's integrationist ideology made transracial adoption a sympathetic idea to many adoption workers and prospective parents. Transracial adoption also served the needs of the waiting white parents, for whom there were not enough color-matched children available, as well as the interests of the agencies in putting together adoptive families and reducing the foster care population. And so agencies began to place waiting black children with white parents when there were no black parents apparently available. The reported number of transracial placements rose gradually to 733 in 1968 , and it more than tripled in the next three years to reach a peak of 2574 in $1971 .^{25}$

23 Ward v. Ward, 36 Wash. 2d 143, 144-45, 216 P.2d 755, 756 (1950). This case was subsequently repudiated in Tucker v. Tucker, 14 Wash. App. 454, 542 P.2d 789 (1975). For a discussion of the history in connection with child custody decisions, see Perry, supra note 17 , at 57-83.

${ }^{24}$ See generally Bartholet, supra note 1 , at 10-6 to 10-7; H. ALTSTEIN \& R. SIMON, INTERCOUNTRY ADOPTION 1-20 (1991).

${ }^{25}$ See R. Simon \& H. AltSTEIN, TRANSRAGIAl Adoption I, supra note 11, at 29-30, 32. These figures do not include the transracial placements that occurred in the independent adoption process, which were generally not reported on a systematic 
Nonetheless, transracial adoption remained suspect in the eyes of many adoption professionals:

Even as the transracial adoption wave crested, the skeptics within the adoption community were never completely silent. They continued to warn that transracial adoption was risky and called for the utmost caution. Many workers were still not convinced that there was evidence that matching parents and child was not important. It had, of course, never been demonstrated that matching was important, but the idea was, until the 1960 s, widely accepted in the profession and well-buttressed with psychiatric opinion. Some conceded that parents could take a lot more differences between themselves and their children than social workers had thought, but they wondered if racial differences might not be too much for many. ${ }^{26}$

Inracial adoption continued to be viewed by the professionals as preferable to transracial adoption. Transracial adoption was accepted and justified only on the ground that it was a better alternative for the children involved than life without any permanerit family. At its peak in 1971, transracial adoption involved the placement of only a tiny fraction of the black children waiting for adoptive homes and roughly half the number of black children placed in black homes. 27

In 1972 this brief era of relative openness to transracial adoption came to an abrupt end. That year an organization called the National Association of Black Social Workers (NABSW) issued a position statement against transracial adoption. It stated:

basis. See Telephone interview with Rita Simon, Co-author of above study (Jan. 25, 1991). One author describes how an early campaign to recruit black adopters stimulated applications from white adoptive applicants and led to experimentation with transracial placements. See D. DAY, supra note 11, at 94 .

${ }^{26}$ Macaulay \& Macaulay, supra note 11, at 285 (emphasis added) (citation omitted). The Child Welfare League revised its 1958 Standards for Adoption Service, supra note 15, in 1963 and again in 1968 in response to the integrationist spirit of the 1960s. It substituted new language indicating a somewhat more favorable attitude towards transracial adoption: "In most communities there are families who have the capacity to adopt a child whose racial background is different from their own. Such couples should be encouraged to consider such a child." CHILD WELFARE LEAGUE OF AMERICA, STANDARDS FOR ADOPTION SERVICE § 4.5 (1968).

${ }^{27}$ In Macaulay \& Macaulay, supra note 11, at 284-85, the authors report that in 1971 there were an estimated 40,000 to 80,000 adoptable black children under agency jurisdiction. In that year 4846 black children were placed in black families for adoption, as compared with 2574 black children who were placed in white homes. In 1971 there were a total of 82,800 reported unrelated adoptions. See ADOPTION FACTBOOK, supra note 5, at 99. 
Black children should be placed only with Black families whether in foster care or for adoption. Black children belong, physically, psychologically and culturally in Black families in order that they receive the total sense of themselves and develop a sound projection of their future. Human beings are products of their environment and develop their sense of values, attitudes and self concept within their family structures. Black children in white homes are cut off from the healthy development of themselves as Black people.

Our position is based on:

1. the necessity of self-determination from birth to death, of all Black people.

2. the need of our young ones to begin at birth to identify with all Black people in a Black community.

3. the philosophy that we need our own to build a strong nation.

We the participants of the workshop have committed ourselves to go back to our communities and work to end this particular form of genocide. ${ }^{28}$

Others joined in the attack on transracial adoption, ${ }^{29}$ arguing with the NABSW that transracial adoption constituted an attack upon the black community and that it harmed black children by denying them their black heritage and the survival skills needed for life in a racist society. ${ }^{30}$

The attack on transracial adoption appeared to have an immediate and significant impact. ${ }^{31}$ The numbers fell from a peak of 2574 in 1971, to 1569 in. 1972, to 1091 in 1973. ${ }^{32}$ By 1975, the last year in which these statistics were systematically generated, the number was $831 .^{33}$ The influential Child Welfare League, which had in 1968 revised its Standards for Adoption Service to encourage

${ }^{28}$ National Association of Black Social Workers, Position Paper (April 1972), reprinted in $\mathrm{R}$. SIMON \& $\mathrm{H}$. ALTSTEIN, TRANSRACIAL ADOPTION I, supra note 11, at 5052.

29 For an interesting description of the reaction to transracial adoption, see J. LADNER, MIXED FAMILIES (1977).

${ }^{30}$ See Chestang, The Dilemma of Biracial Adoption, 17 Soc. WORK 100, 100-01 (1972).

${ }^{31}$ See D. DAY, supra note 11, at: 99-100, 112 \& n.103.

32 See R. SIMON \& H. ALTSTEIN, TRANSRACIAL ADOPTION I, supra note 11, at 30.

${ }^{33}$ See R. Simon \& H. Altstein, TRANSRACIAl ADOPTION II, supra note 11, at 96. Although there was also a decline in the total numbers of unrelated adoptions during this period, that decline was not as dramatic. See ADOPTION FACTBOOK, supra note 5 , at 99 (indicating that unrelated adoptions fell from 82,800 in 1971 to 47,700 in 1975). 
consideration of transracial adoption, ${ }^{34}$ revised its standards once more in 1973 to re-emphasize the advantages of same-race placements. ${ }^{35}$ Adoption agency bureaucrats moved swiftly to accommodate the position taken by the NABSW. ${ }^{36}$ A study of the phenomenon gives a persuasive explanation of the dynamics:

When the black social work community turned professional attitudes around, it seemed prudent to do such things as to turn responsibility for all black children over to black social workers and agencies. The transracial adoptive parent organizations might be unhappy, but they were less of a threat than black power exercised directly or through the workers' professional peers. ${ }^{37}$

A parallel development occurred with respect to the adoptive placement of Native American children. Indian children were first placed in significant numbers in non-Indian homes in the period from the late 1950s through the 1960s. Certain Native American leaders took a public position against these placements in 1972, the same year the NABSW issued its historic statement against transracial adoption. ${ }^{38}$ Several years later Congress passed the Indian Child Welfare Act of $1978^{39}$ which mandates a powerful preference for placing Indian children with Indians as opposed to nonIndians. The Act gives priority first to the child's extended family, second to members of the child's tribe, and third to other Indians. ${ }^{40}$ Non-Indians can be considered only as a last resort. As one scholar has written: "A basic assumption of the Act is that Indian children are essential tribal resources ...."11 This assumption finds expression in provisions that expand the jurisdiction of tribal courts to decide cases involving Indian children and in provisions

${ }^{34}$ See supra note 26; see also R. Simon \& H. AltSTEIN, TRANSRACIAL ADOPTION II, supra note 11 , at 96 .

${ }^{35}$ The 1973 standards provided: "It is preferable to place children in families of their own racial background." CHILD WELFARE LEAGUE OF AMERICA, STANDARDS FOR ADOPTION SERVICE $§ 4.5$ (1973). The rationale was that "[i]n today's social climate children placed in adoptive families with similar racial characteristics can become more easily integrated into the average family group and community." Id.

${ }^{36}$ See Macaulay \& Macaulay, supra note 11, at 294-800.

${ }^{37} \mathrm{Id}$. at 298.

${ }^{38}$ See Simon, An Assessment of Racial Awareness, Preference, and Self-Identity Among White and Adopted Non-White Children, 22 Soc. ProBs. 43, 45 (1974).

${ }^{39}$ Pub. L. No. 95-608, 92 Stat. 3069 (codified at 25 U.S.C. $\$ \S 1901-63$ (1988)).

${ }^{40}$ See 25 U.S.C. \$ 1915(a) (1988).

41 Hollinger, Beyond the Best Interests of the Tribe: The Indian Child Welfare Act and the Adoption of Indian Children, 66 U. DET. L. REV. 451, 456 (1989). 
that give tribes a right, separate from and independent of any parental right, to be heard on the fate of such children. ${ }^{42}$

Congress did not pass a law specifically mandating an inrace placement preference for black children or officially proclaiming that black children belong to the black community. ${ }^{43}$ But as I will show in Part III, a powerful inrace placement preference has nonetheless been established. Adoption agencies have played a major role in establishing this preference. They have used the massive discretion accorded them by adoption laws to create racial policies that would be difficult for legislators to justify politically, ${ }^{44}$ in part because they are of questionable legality given constitutional and legislative guarantees against discrimination based on race. ${ }^{45}$ But adoption agencies have operated with the cooperation, and often times the active encouragement, of state and federal legislators and officials responsible for regulating and funding adoption activities, as well as the courts. ${ }^{46}$ In recent years several states have passed laws modelled on the Indian Child Welfare Act, mandating a same-race preference in adoptive placement. ${ }^{47}$ The federal government has not played as direct a role as state governments since it is the states that run the public adoption agencies and are responsible for regulating the private agencies. But the federal government has nonetheless played a major role in encouraging same-race placement policies. It has taken major initiatives to fund the subsidies and the adoption information exchange systems that operate to recruit families on a same-race basis. ${ }^{48}$ And it has administered the civil rights laws governing adoption agencies that receive federal funds in such a way as to specifically authorize the use of race in adoption decisionmaking. ${ }^{49}$

${ }^{42}$ See id. at $456-57 ; 25$ U.S.C. 1911 (a)-(c) (1988).

${ }^{43}$ The NABSW has proposed a "National Black Heritage Child Welfare Act" which would amend the Indian Child Welfare Act by providing somewhat comparable provisions mandating preferences for placement of all minority children with families of the same racial or ethnic heritage. See NAT'L ASs'N OF BLACK SOCIAI. WORKERS, INC., PRESERVING BLAGK FAMILIES: RESEARGH AND ACTION BEYOND THE RHETORIC 49 (1986) [hereinafter Preserving BlaGk Families].

44 See Macaulay \& Macaulay, sicpra note 11, at 294-95.

45 See infra Part VI.

${ }^{46}$ See infra Part III and text accompanying notes 188-93 \& 211-22.

47 See infra text accompanying notes 65-67.

${ }^{48}$ See infra text accompanying notes 81-90.

${ }^{49}$ See infra text accompanying notes 188-93. 


\section{Current Racial Matching Policies ${ }^{50}$}

The available evidence indicates that today most public ${ }^{51}$ and

${ }^{50}$ As discussed below, these policies are generally unwritten, and there are no studies documenting their exact nature or systematically analyzing the impact they have on children in terms of such factors as delay in or denial of permanent placement. See infra text accompanying notes 55-57.

In my investigation of the facts for purposes of this Article, I relied on a general review of the relevant literature and case law, my own experience as a consultant on adoption issues and as an adoptive parent, and a series of interviews, some by telephone and some in person, with dozens of adoption world professionals, students of the adoption system, and related experts, including both critics and supporters of current racial matching policies. Those interviewed include the following: Richard Barth, Professor, School of Social Welfare, University of California, Berkeley; Betsy Burch, Director, Single Parents for the Adoption of Children Everywhere (SPACE); Alice Bussiere, National Center for Youth Law; Carol Coccia, President, National Coalition to End Racism in America's Child Care System; Sydney Duncan, Director, Homes For Black Children; Jane Edwards, former Director, Spence Chapin Adoption Service; Susan Freivalds, Adoptive Families of America; Carolyn Johnson, Executive Director, National Adoption Center; Joe Kroll, Executive Director, North American Council on Adoptable Children; Betty Laning, Open Door Society; Ernesto Loperena, New York Council on Adoptable Children; Phyllis Lowenstein, former Director, International Adoptions Inc.; Leora Neal, Executive Director, New York Chapter of Association of Black Social Workers Child Adoption Counselling and Referral Service; William Pierce, President, National Committee for Adoption; Dr. Alvin Poussaint, Department of Psychiatry, Harvard Medical School; Nancy Rodriguez, Supervisor, Adoption Subsidy Program, Massachusetts Department of Social Services; Mary Beth Seader, National Committee for Adoption; Rita Simon, Co-author of one of the leading empirical studies of transracial adoption; Carolyn Smith, Massachusetts Adoption Resource Exchange; Peggy Soule, Director, The CAP Exchange; Linda Spears, Director, Office of Special Projects, Massachusetts Department of Social Services; Toshio Tatara, Director, Research and Demonstration Department, American Public Welfare Association; Ken Watson, Child Welfare League of America Adoption Task Force and Chicago Child Care Society; Mary Wood, Native American Adoption Resource Exchange.

In addition, I asked several of these people, as well as many others who have studied adoption and racial matching in the context of adoption, to review an earlier draft of this Article, and I used their written and oral comments in refining my description of the policies and their impact.

In this and subsequent sections of this Article, I rely on the conclusions drawn from this investigation. I rarely cite to specific people as sources for particular pieces of information. Sometimes this is because the information is widely known and noncontroversial. Other times this is because the information is controversial or sensitive, and I do not want to risk unnecessary embarrassment to persons who were willing to talk to me on a forthright basis. It is an unfortunate aspect of the politics of the current debate that many persons who are highly critical of current racial matching policies are fearful of expressing their views publicly. Notes of my interviews and written comments upon which I rely are available in my files at the Harvard Law School.

${ }^{51}$ I use the term "public adoption agency" to refer to the state agencies authorized to arrange adoptive placements. These are often the same agencies that initially assume jurisdiction over children who are surrendered, abandoned, 
private adoption agencies ${ }^{52}$ are governed by powerful race matching policies in making placement decisions for the children who come under their jurisdiction. There is very general agreement among adoption agency policy-makers that children should be placed inracially "if possible," and transracially only "if necessary" or as a last resort. There is, however, enormous variation among adoption agencies. Some of the private agencies are quite open to transracial adoption, and there is reason to think that the private agencies as a group are generally more open to such adoption than the public agencies. ${ }^{53}$ But public matching policies control to a significant degree private agencies, either through the regulatory process or through contracts for services. Public agencies also have under their jurisdiction a disproportionate share of the minority children available for adoption. Recognizing the variety among agencies, I will try to give a sense for the nature of the policies that govern placement in most public and traditional private agencies. ${ }^{54}$

Unfortunately, there has been no systematic documentation of the specifics of current racial matching policies and how these specific policies affect children in terms of delay in or denial of permanent adoptive placement. ${ }^{55}$ This is particularly problematic because of the hidden nature of the policies at issue. They are

orphaned, or removed from the custody of their biological parents.

${ }^{52}$ I use the term "private adoption agency" to refer to the agencies that are generally organized in a not-for-profit corporation form and are licensed by the state to arrange adoptive placements. These agencies may receive children for placement from the state agencies described supra note 51, or directly from biological parents.

${ }^{53}$ Nonetheless, it appears that very few transracial adoptions are taking place. One recent survey examining this issue indicates that $1.2 \%$ of all adoptions involve a white mother and a black child and that $92.4 \%$ of all adoptions involve a same-race mother and child. The transracial adoptions include children born in other countries as well as in the United States. See ADOPTION IN THE 1980's, supra note 4, at 5-7.

${ }^{54}$ The same matching policies do not apply in the independent adoption world where birth parents and private intermediaries make the placement decisions with limited intervention by the state or state-licensed adoption agencies. Here, race may or may not play a major role in placement decisions, depending on the views of the individuals and organizations involved.

All but a handful of states permit birth parents to place children with nonrelative prospective adopters either directly or with the assistance of an unlicensed intermediary. See Hollinger, supra note 10, at 1-36. For discussion of the agency and independent adoption processes, see $i d$. at 1-62 to 1-67.

55 There does exist a significant body of literature arguing the pros and cons of transracial adoption and a body of empirical research assessing the experience of transracial adoptees. See infra Part V \& note 170. There is also an abundance of literature analyzing the impact that delay in and denial of permanent adoptive placement has on children. See infra text accompanying notes 162-66. 
generally unwritten, and what is written may give few clues or even false clues as to the unwritten reality. ${ }^{56}$ In addition, those in a position to know what today's racial matching policies look like are often reluctant to disclose what is going on for fear of attack by people on different sides of the matching issue. ${ }^{57}$

Although a study systematically documenting the nature and impact of existing racial matching policies would be extremely useful, it is possible without that study to get a general sense for these matters. My own investigation has included interviews with a wide array of leaders in the adoption world and experts on racial matching policies, together with a review of the relevant literature. ${ }^{58}$

This investigation has made clear to me that race is used as the basis for official decision-making in adoption in a way that is unparalleled in a society that has generally endorsed an antidiscrimination and pro-integration ideology. This investigation has also made clear that current policies have a severe impact on minority children, often causing serious delays in or permanent denial of adoptive placement. In the remainder of Part III and in Part IV of this Article I will flesh out my findings in more detail.

${ }^{56}$ For example, the Connecticut legislature passed a bill in 1986 providing that the State "shall not refuse to place ... [ [a child in its custody] with any prospective adoptive parent solely on the basis of a difference in race." CONN. GEN. STAT. ANN. $\$$ 45-61(1) (West Supp. 1990). An implementing Task Force subsequently issued a report that constituted an agenda for promoting inrace placement. See TASK FORCE ON TRANSRACIAL ADOPIION, OFFICE OF POLICY AND MANAGEMENT, COMPREHENSIVE PlanNING DIVISION, A STUdy OF TRANSRacial ADOPTION IN THE STATE OF CONNECTICUT 7, 27 (1988) [hereinafter A STUDY OF TRANSRACIAL ADOPTION]; see also 1 WESTAT, INC., ADOPTIVE SERVICES FOR WAITING MINORITY AND NONMINORITY CHILDREN H4-11, H4-14 (Apr. 15, 1986) [hereinafter WESTAT REPORT] (noting that at the time of the study New York "State Standards" prohibited use of race as a basis for rejection, yet a major state adoption program required that children be placed "in a home as similar to and compatible with his or her ethnic, racial, religious, and cultural background as possible").

${ }^{57}$ Adoption agencies that are relatively open to transracial placement have reason to fear that if they disclose their policies they will subject themselves to attack by the NABSW and other opponents of transracial adoption and risk sanction by the regulatory bodies and public or private funding entities that require or promote same-race matching. Adoption agencies that refuse to consider transracial placements for children for whom there are no available same-race families have reason to fear attack by white would-be adoptive parents and adoptive parent support groups and have reason to think that their policies are legally vulnerable. See infra Part VI. One organization that has been active in encouraging legal challenges to racial matching policies is the National Coalition to End Racism in America's Child Care System, founded in 1984.

${ }^{58}$ See supra note 50. 


\section{A. A Picture of the Matching Process at Work $^{59}$}

An initial order of business for most adoption agencies is the separation of children and prospective parents into racial classifications and sub-classifications. Children in need of homes are typically separated into black and white pools. The children in the black pool are then classified by skin tone-light, medium, dark-and sometimes by nationality, ethnicity, or other cultural characteristics. The prospective parent pool is similarly divided and classified. An attempt is then made to match children in the various "black"

59 This Article focuses on race matching policies in the context of placement for adoption rather than foster care. However, it is important to note that the issues are closely related. Foster care was originally conceived of as a short-term form of care, designed to provide for the child on a temporary basis pending return to the biological family or transfer to a permanent adoptive family. A variety of forces, however, have transformed the nature of foster care. Children have often ended up living in foster care for many years and sometimes for their entire childhood. As discussed later in this Article, racial matching policies have contributed to this phenomenon. See infra Parts III $\&$ IV. But many other factors have contributed as well, including a powerful reluctance to cut off a child's ties to his biological family and court delays in terminating parental rights. As foster care has become for many children a more long-term form of care, it has to some degree been reconceived. Adoption workers now tend to encourage a child's foster parents to consider permanent adoption. In Massachusetts, Department of Social Service figures indicate that $65 \%$ of adoptions in recent years have been by foster parents. See Telephone interview with Linda Spears, Massachusetts Department of Social Services (Jan. 25, 1991). Increasingly, foster parents are chosen with a view towards permanent adoption in the future, or with a view towards a long-term foster care relationship in cases where it seems unlikely that the relationship with the biological parents will be terminated.

To the degree that foster care functions as a long-term form of substitute family care or a transitional step to adoption, the placement issues are very much the same as those that arise in the context of adoption. Not surprisingly, it appears that the race matching policies are quite similar. Indeed, adoption workers have made it an increasing priority to place children with same-race foster families in recent years because of the long-term nature of much foster care and because in cases where an adoption is contemplated, the workers want a same-race foster family to be in the priority position to become the adoptive parents should they wish to adopt. See infra text preceding note 74 .

Accordingly, although the specifics of the foster care situation are beyond the scope of this Article, it should be clear that the principles discussed here, in the context of adoptive placement, are to a significant degree applicable to the closely related issue of foster care placement.

Even though the general understanding is that, for many children, foster care has become a long-term form of care, recent APWA statistics indicate that the length of stay for most children in out-of-home care has grown shorter, not longer, during recent years. The median length of stay for those still in care declined from 1.7 years in 1982 to 1.3 years in 1987. Ten percent of the children in care had stayed 5 years or longer in 1987, as compared to 1982 when $10 \%$ stayed. 7.4 years or longer. See Tatara Interview, supra note 10. 
categories with their parent counterparts. The goal is to assign the light skinned black child to light skinned parents, the Haitian child to Haitian parents, and so on. ${ }^{60}$ The white children are matched with white prospective parents.

This matching scheme confronts a major problem in the fact that the numbers of children falling into the black and the white pools do not "fit," proportionally, with the number of prospective parents falling into their own black and white pools. In 1987, 37.1\% of the children in out-of-home placement were black as compared with $46.1 \%$ white. $^{61}$ Although no good statistics are available, the general understanding is that a very high percentage of the waiting adoptive parent pool is white. In addition, many whites interested in adopting do not bother to put themselves on the waiting lists because of their understanding that there is such a limited number of children available to them. ${ }^{62}$

${ }^{60}$ The former director of a major adoption agency in the Boston area told me of a case involving Haitian infant twins who were held in foster care for one year while the agency waited for prospective parents who were also Haitian, then held for another two years while the agency waited for black parents who spoke fluent French. Only after three years did the agency permit placement with a waiting black family that did not satisfy these criteria. See generally Interviews, supra note 50 . An interracial couple (white husband and black wife) that recently applied to a District of Columbia adoption agency was told by the agency that they would be placed very low on the priority list for a mixed race child. The first preference was to assign such a child to a couple who were both mixed race, with darker skinned black husband and wife couples next in line, and black singles third. See id.

61 These are APWA statistics obtained during my interview with Dr. Toshio Tatara. See Tatara Interview, supra note 10. Of the children legally free for adoption, $34.1 \%$ were black and $52.5 \%$ were white in 1987 . See id. It is not clear which are the most significant figures. As indicated infra text accompanying note 76 , blacks may not be freed for adoption unless black families are thought to be available for them.

By contrast to their numbers in the foster care population, blacks represent only $12.3 \%$ of the general population. See U.S. DEP'T OF COMMERCE, STATISTICAL ABSTRACT OF THE UNITED STATES 1990, at 12 (1990).

${ }^{62}$ See supra notes 4-5. The APWA statistics do not include information on waiting families. However, a study done for the Child Welfare League provides some documentation of the numbers mismatch. See J. MUNNS \& J. COPENHAVER, supra note 10, at 8. The 1991 figures for The National Adoption Center exchange, which lists hard-to-place children waiting for homes as well as waiting families, provide further documentation. They show that $67 \%$ of the listed children are black, and $26 \%$ are white. See Memorandum from Director Carolyn Johnson to Staff 1-2 (Mar. 28, 1991) (on file with author). Of the waiting families, $31 \%$ are black and $67 \%$ are white. See Fax Transmittal Memorandum from Director Carolyn Johnson to Elizabeth Bartholet (Apr. 16, 1991) (on file with author). The Massachusetts Adoption Resource Exchange figures for December 1990 show that, of the children registered with the Exchange, 121 were of color and 198 were white. Of the families registered, 41 were of color and 281 were white. Of the 281 white families, 161 were listed as being interested in children over the age of 6 and 120 were listed as being interested in 
The matching policies of today place a high priority on expanding the pool of prospective black adoptive parents so placements can be made without utilizing the waiting white pool. As discussed below, programs have been created to recruit black parents, subsidies have been provided to encourage them to adopt, and traditional parental screening criteria have been revised.

Nonetheless, the numbers mismatch continues. There are many more black children than there are waiting black families. There is a large pool of waiting white families. In recent years both the number of children in foster care and the proportion that is black have been growing. ${ }^{63}$

Today's matching policies generally forbid the immediate placement of black children available for adoption with waiting white families. These policies, discussed below, tend to preclude such placements, either implicitly or explicitly, for periods ranging from six to eighteen months to several years or longer. In many instances the policies preclude placement altogether.

The matching process surfaces, to a degree, in written rules and documented cases. But it is the unwritten and generally invisible rules that are central to understanding the nature of current policies. Virtually everyone in the system agrees that, all things being equal, the minority child should go to minority parents. Thus by the universal rules of the official game, race matching must be taken into account in the placement process. But this vastly understates the power of racial matching policies in the official adoption world. The fact is that the entire system has been designed and redesigned with a view towards promoting inracial placements and avoiding transracial placements. The rules generally make race not simply "a factor," but an overwhelmingly important factor in the placement process. The policies at issue take the following forms. ${ }^{64}$

children under 6. See Telephone interview with Carolyn Smith, Massachusetts Adoption Resource Exchange (Jan. 24, 1991).

${ }^{63}$ See supra note 10.

64 The description which follows is largely based on the investigation described supra note 50. See also WESTAT REPORT, supra note 56. In reporting on an in-depth study of the practices of eight major state adoption programs throughout the nation, the WESTAT authors found that " $[\mathrm{t}]$ he policy or practice in every agency visited indicated a preference for same race placements for children waiting [for] adoptive placements." Id. at 4-22. The report describes these policies as strong ones, often requiring documentation of the unavailability of same race families or administrative approval before transracial placements could be made. The report also discusses the methods these agencies use to promote inrace adoption, including special recruitment 


\section{B. The Proverbial Tip of the Iceberg-Of Written Rules and Documented Cases}

\section{Laws, Regulations, and Policy Guidelines Mandating Consideration of Race in the Placement Decision}

In recent years, several states have written into law requirements that agencies exercise a same-race preference in placing children in adoptive families. Minnesota and Arkansas have laws specifying a preference for placement with a family of the same racial or ethnic heritage. If a same-race placement is not feasible, the preference shifts to "a family of different racial or ethnic heritage from the child which is knowledgeable and appreciative of the child's racial or ethnic heritage. ${ }^{n 65}$ California law similarly mandates a samerace placement preference, and, in addition, it prohibits placement across racial or ethnic lines for a period of ninety days after a child has been relinquished or declared free for adoption. The law further prohibits such adoption after the ninety day period "unless it can be documented that a diligent search" for a same-race family has been made, using all appropriate recruitment resources and devices. ${ }^{66}$ Only on the basis of such documentation can a child be placed across racial or ethnic lines with a family "where there is evidence of sensitivity to the child's race, ethnicity, and culture."

Other states have regulations or written policies that similarly provide for racial preference in the placement process. Some of these, like the California law, specify mandatory waiting periods during which children must be held in hopes of an inrace placement before a transracial placement can be considered. ${ }^{68}$

programs, subsidies, and alterations in traditional agency criteria. See id. at 4-14 to 4-30.

${ }^{65}$ MINN. STAT. ANN. §§ 259.255, 259.28 (West Supp. 1991); ARR. STAT. ANN. § 99-102 (1987). Minnesota regulations and guidelines define a family which is "knowledgeable and appreciative" as "one which has personal relationships with persons of the child's minority heritage ... resides in an integrated neighborhood, or demonstrates its ability to meet the cultural needs of a minority child in a multiracial family:" A STUDY OF TRANSRACIAL ADOPTION, supra note 56, at 74 (quoting Minnesota Department of Public Welfare Regulations).

${ }^{66}$ See CAL. CIv. CODE $§ \S 276,276(2)$ (West Supp. 1991), amended by CAL. Crv. CoDE $\S \S 222.35,222.37$ (West Supp. 1991) (effective July 1, 1991).

${ }^{67}$ Id. $\$ 276(c)$, amended by id. $\$ 222.35$.

68 New York State regulations require that adoption agencies "[m]ake an effort to place each child in a home as similar to and compatible with his or her ethnic, racial, religious, and cultural background as possible . . ." N.Y. COMP. CODES R. \& REGS. tit. 18, $\$ 421.18(c)(1990)$. Massachusetts regulations mandate a preference in 
The Child Welfare League's current Standards For Adoption Service, ${ }^{69}$ designed to establish standards for adoption agencies throughout the country, provides: "Children in need of adoption have a right to be placed in a family that reflects their ethnicity or race." ${ }^{20}$ The current policy position of the National Committee For Adoption states: "Usually, placement of the child should be with a family of a similar racial or ethnic background. ${ }^{\text {71 }}$

"substitute care" placement for "a family of the same racial or ethnic or linguistic heritage or background ...." MASS. REGs. CODE tit. 110, $\$ 7.101(1)(d)$ (1986). Although on its face this regulation appears to apply only to foster care, it is read by Massachusetts policy-makers as applicable to adoptive placements as well. See Telephone interview with Sara Sneed, Special Assistant to the Director, Office of Special Projects, Massachusetts Department of Social Services (Mar. 6, 1991). Georgia Regulations require that agencies "give consideration to a child's racial, cultural, ethnic . . heritage and preserve them to the extent possible without jeopardizing the child's right for placement and care." GA. COMP. R. \& REGS. r. 290-2-12-.06(17) (1987).

I have conducted no general search for additional examples of such written policies. However, the Connecticut report cites a few. See A STUDY OF TRANSRACIAL ADOPTION, supra note 56, at 72-73. The following description is taken from there. Arizona's "Policy of Placement of Children with Families of the Same Ethnic or Racial Background" provides for same-race placement preferences in the following order: (1) adoptive parents of the child's racial or ethnic background and (2) a two parent family in which one parent is of the child's racial or ethnic background. Other families may be considered only after intensive recruitment efforts to find a racially matched family have been made, the unavailability of such a family has been documented, and a three month time period has passed. See id. at 72. A Nevada Social Services Manual similarly provides for same-race placement preference. Transracial placement is permitted only if a diligent search fails to produce a racially matched family and only after passage of a three month period. See id. at 73. A Missouri Department of Social Services handbook provides that placement of a child with a family of dissimilar racial or ethnic heritage can be made only after specified recruitment efforts have failed to locate a racially matched family and a period of six months has passed since the child became available for adoption. See id. at 72. A South Carolina Department of Social Services Manual provides a same-race placement preference, and it sets twelve months from the time the child is freed for adoption as the maximum period for searching for a same-race family. See id. at 73 .

${ }^{69} \mathrm{~S} e \boldsymbol{e}$ Child Welfare League of AMERICA, STANDards for Adoption SERVice (1988).

${ }^{70}$ Id. at 34. The Standards for Adoption Service make clear that although some delay in placement while same-race placement efforts are pursued may be appropriate, significant delay or denial of placement is not: "Children should not have their adoption denied or significantly clelayed, however, when adoptive parents of other ethnic or racial groups are available. ... If aggressive, ongoing recruitment efforts are unsuccessful in finding families of the same ethnicity or culture, other families should be considered." Id. at 34-35.

71 National Committee for Adoption, Statement by the Executive Committee (Aug. 4, 1984), reprinted in ADOPTION FACTBOOK, supra note 5, at 124. The policy position goes on to specify that placement should not be "unduly postponed" or permanent placement denied because of the unavailability of a same-race family. See 
The existence and the recency of these kinds of laws, regulations, and policy guidelines hint at the power and the current popularity of the racial matching policies that lie beneath the level of written policies; normally in our society there is a reluctance to put into written form requirements that race be a factor in decisionmaking. However, the unwritten policies are far more extreme in their promotion of racial matching than any written policies would suggest.

\section{Cases Documenting the Removal of Black Children from White Foster Families to Prevent Transracial Adoption}

Numerous cases have surfaced in the media, in congressional hearings, and in litigation involving the removal of black children from white foster families with whom they have lived for long periods, often years. In some cases removal is triggered by the white family's expression of interest in adopting their foster child, and the agency intervenes to move the child to a same-race foster family which may or may not be interested in adoption. In other cases the agency removes the child simply because a same-race foster family has become available. The white parents have poignant stories to tell. ${ }^{72}$ Often they have been given a child in

id. The National Committee For Adoption is an organization which sees itself as representing not-for-profit adoption agencies, as well as the parents and children involved in the adoption process.

72 See, e.g., McLaughlin v. Pernsley, 693 F. Supp. 318 (E.D. Pa. 1988), affd on other grounds, 876 F.2d 308 (3d Cir. 1989). This case involved a black child who was removed from his white foster parents with whom he had lived for two years, since the age of four months. He had flourished in their home, and they were prepared to adopt him if reunification with his biological family was ruled out. Upon removal to a black foster family the child fell into a severe depression. Almost three years later a federal district court granted a preliminary injunction ordering that the child be returned to his white foster parents, on the ground that he had originally been removed solely on the basis of race, and was still suffering from depression as a result of his removal.

Another case that was successfully challenged involved a black child who had been bounced through various foster homes. He was developmentally delayed and in poor health when he was placed with a white foster family. During a year with this family he developed a close relationship and made significant developmental progress. Nonetheless, he was removed by the Michigan Department of Social Services so that he could be placed with a black foster mother. A federal lawsuit filed by The National Committee to End Racism in America's Child Care System resulted in a court finding that the child's removal on the basis of race violated the Constitution and a consent decree limiting the use of race by the Department of Social Services. See American Civil Liberties Union, Press Release (Sept. 24, 1985) (on file with author); Committee to End Racism in Michigan's Child Care Sys. v. Mansour, No. 
very poor physical or psychological shape, or with serious disabilities, and have nursed the child through hard times. The child has thrived under their care and feels a close attachment. They feel a similar attachment and want to adopt so that the child will be a permanent part of their lives. The agency can offer nothing but a shift to a new foster family as an alternative. Experts testify to the destructive impact that disruption of the only stable relationship the child has known will have. Adoption agencies may or may not be forced to back down in these cases, whether by public pressure or by court order. But either way, these cases reveal something of the power of the racial matching policies operating in the adoption agency world, since there is very general agreement among today's child welfare professionals that stable parent-child relationships should not be disrupted and that appropriate foster families should be given priority consideration for the adoption of children with whom they have formed such relationships. These cases are fought out in the public eye not because they are particularly extreme examples of the racial matching policies at work, but because the decision to remove the child, and the crucial role race plays in that decision, are highly visible. ${ }^{73}$

85CV7438DT (E.D Mich. Jan. 13, 1986) (consent decree) (on file with author along with transcipt of proceedings). See also Dobie, Nobody's Child: The Battle Over Interracial Adoption, VILLAGE VOICE, Aug. 8, 1989, at 18-26 (documenting a series of sad stories involving the removal of black children from white foster parents); National Coalition to End Racism in America's Child Care System, The Children's Voice Newsletter (Apr.-June 1990) (memorializing a foster child who died at the age of 14 months, an apparent victim of child abuse, after transfer from white foster family to black foster family for inracial matching reasons).

73 The courts are prepared to give foster parents at least a limited opportunity to challenge agency decisions that involve the removal of a child. See Smith v. Organization of Foster Families for Equality \& Reform, 431 U.S. 816 (1977); Drummond v. Fulton County Dep't of Family \& Children's Servs., 563 F.2d 1200 (5th Cir. 1977) (en banc).

By contrast, other types of placement decisions are largely invisible. Prospective parents who approach an agency may simply be told that certain children will or will not be made available to them. It is difficult for these parents to get a sense of the nature of the agency's racial matching policy. They may feel dependent on the agency for finding a child to adopt and thus fearful of raising a challenge. If they do try to challenge the agency, it is easy for the adoption professionals to hide race among the array of factors they allegedly used in their highly subjective and discretionary assessment of what placement was in the "best interest of the child"-the broad standard that is supposed to guide agency decisionmaking. Courts are unlikely to intervene to help bring to the surface what is going on in the ordinary placement decision. Agencies are treated essentially as parents, with near-absolute discretion to decide what to do with the children within their custody; prospective adopters will often be told they have no standing whatsoever to bring a challenge in court. 
Although these child removal cases tell us something about the powerful role race plays in agency decisionmaking, they do not tell us much about the specifics. It is not clear how common these policies ever were or are today. Racial matching policies apply to foster care placement as well as to adoptive placement, so that a relatively small number of black children are placed in white foster homes. In recent years there has been an even greater priority placed on racial matching in foster care, at least in part out of concern that such placements can lead to permanent adoption. ${ }^{74}$

However, state welfare systems often have difficulty finding sufficient numbers of same-race foster homes for the increasing number of minority children in need of substitute care. Adoption workers often have no choice as they look for temporary homes for "crack babies" and older children removed from their families or surrendered, except to place them with white foster parents. Current policies often make it difficult or impossible for those parents to adopt and require the removal of the child for a samerace foster or adoptive placement, however bonded and committed the white family and its black foster child may become. ${ }^{75}$

\section{Key Features of the Matching System}

\section{Holding Policies}

Agency policies typically involve holding black children in foster or institutional care for significant periods of time after they are or could be free for adoption if no same-race adoptive family is available. Consideration will not be given during this time to placement with available white families. Sometimes the policies specify a definite time period-three or six or twelve or eighteen months-before a transracial adoption may be considered, or after which it must be considered. But even these time-specific policies give no real sense for the length of the holding periods at issue

Similarly, children held for years in foster care are not likely to know what opportunities for permanent placement they missed, and even if they did know, they would have as a practical matter even more limited access to the legal system to challenge the denial of those opportunities.

74 See supra note 59; see also WESTAT REPORT, supra note 56, at xiv, 4-15 (noting that the trend towards foster parent adoption has led to increased emphasis on racial matching in foster care).

${ }^{75}$ See D'Antonio, Sad Goodbye to Michael: White Foster Parents Must Surrender Black Infant NEWSDAY, April 1, 1988, at 3, 27 (documenting placement of boarder babies with white foster families and subsequent removal for same-race placement); Tal, Law 
since the time generally starts to run only from the date that a child becomes legally free for adoption. Adoption workers often will not begin the process of freeing a child for adoption until and unless there is a same-race family available. ${ }^{76}$ Assuming that an agency does eventually succeed in finding a same-race family for a waiting child, it may be several more years before the child can actually be placed. The court process terminating the biological parents' rights can easily consume two to four years, ${ }^{77}$ and the newly recruited family will generally have to go through the home study process before placement can occur.

Many policies simply require that children be held until active efforts to locate same-race families have proved fruitless, or until documentation has been submitted regarding such efforts and the unavailability of a same-race family. Many adoption professionals feel that under these non-time-specific policies black children are held for even longer periods. ${ }^{78}$

Breaking up Foster Familes, White Parents with Black Child Targeted, Minn. Star Tribune, Oct. 31, 1990, at 1A, col. 1, 13A, col. 3 (reporting that black advocates of same-race placement demanded removal of all 105 black children living in non-black foster families in Hennepin County); Prince, Black Foster Homes in Short Supply, Minn. Star Tribune, April 30, 1990, at 1A, col. 1, 12A (relating that black children placed in white foster homes because of shortage of black foster homes were subsequently removed for same-race placement).

${ }^{76}$ See Interview with Betty Laning, Open Door Society, in Boston (Dec. 13, 1990); WESTAT REPORT, supra note 56, at D4-2.

${ }^{77}$ See Telephone interview with Linda Spears, Massachussetts Department of Social Services (Jan. 25, 1991). Ms. Spears stated that in the 10 years she had been working in the Massachusetts adoption system, the average time for court procedures terminating parental rights had ranged from two and one-half to four years from the time a child was identified for adoption. See also J. Boyne, L. Denby, J. Kettenring \& W. Wheeler, The Shadow of Success: A Statistical Analysis of Outcomes of Adoptions of Hard-to-Place Children 57 (1982) (unpublished manuscript) (disclosing that for $84 \%$ of the children in a New Jersey study, the process of freeing them for adoption took at least two years).

${ }_{78}$ A number of people with whom I spoke indicated that a rule setting a twelve month or other specific maximum is far preferable because it indicates that there should be at least some limit on the time a child can be held without considering transracial placement.

Some indication of the prevalence of mandatory delay policies and the significant length of the periods involved is revealed by the position taken by the National Committee For Adoption. The Committee's policy statement on transracial adoption endorses the principle of an inrace placement preference, but criticizes the excessive delays in placement that it feels have resulted from the way agencies have implemented that principle. See supra note 71 and accompanying text. The statement concludes:

Our ultimate goal is placing children as soon as they are legally free for adoption. Waiting six months to place a healthy infant would be deemed unsound. We must come to the point where it is considered unsound for any special 
It seems likely that the rules officially mandating only a limited inrace preference will often function in a more absolute way. Rules requiring social workers to provide documentation of their minority family recruitment efforts before transracial placements will be permitted place the social worker who contemplates making such a placement in the position of doing additional work and incurring the other costs involved in making an exception to the general rule. Such a social worker also risks invoking the wrath of the NABSW and other vocal critics of transracial adoption. The overburdened and underpaid adoption worker has every incentive to avoid the multiple troubles promised by transracial placement. ${ }^{79}$

Policies amounting to absolute or near-absolute bans on transracial adoption appear common. The NABSW continues to take an absolute stance against transracial adoption: "NABSW steadfastly holds to the position that Black children should not be placed with white parents under any circumstances ... ." 80 There appear to be many adoption workers who are either sympathetic with the NABSW's position or feel intimidated by NABSW advocates and by others who oppose transracial adoption except in the most limited circumstances.

A sense of the extreme nature of current holding policies is revealed by the stories of some of the transracial adoptions that are allowed to take place. One director of an adoption program for minority children in New York State told me that $99 \%$ of his

needs child, including a child of minority or mixed racial or ethnic background, to wait for six months while a search for a home that is racially or ethnically matching is sought.

National Committee for Adoption, Statement by the Executive Committee (Aug. 4, 1984), reprinted in ADOPTION FACTBOOK, supra note 5, at 124 (emphasis added).

${ }^{79}$ Cf. Macaulay \& Macaulay, supra note 11, at 298-99 (discussing perceived "risks of punishment" which have affected white adoption professionals' shifting attitudes toward transracial adoption over the past few decades).

${ }^{80}$ Preserving BLACK FAMILIES, supra note 43, at 31. "Over the last 14 years, NABSW has labored relentlessly in its efforts to oppose transracial adoption .... NABSW herewith reaffirms its position against transracial adoption ...." Id. at 3031. The NABSW's current "position paper" on transracial adoption takes an absolute stance against transracial adoption, supports policies which "mandate" same race placement, and suggests no situation in which transracial placement would be appropriate. See NABSW, Position Paper on Transracial Placements (1986) (unpublished paper on file with author).

The NABSW takes the position that transracial adoption is unnecessary. It contends that (1) more resources should be devoted to maintaining the black biological family thereby reducing the need for adoption, and (2) more resources should be devoted to recruiting black adoptive families and to eliminating various barriers that stand in the way of their adopting. See id. 
agency's placements were inrace placements. He then described one of the few transracial placements he had facilitated. The child had been in the foster care system for eleven years and free for adoption for eight of those years. He was finally placed transracially at the age of thirteen only because of concern that as a result of accumulated bitterness over the years he would be likely to exercise the option he would get at age fourteen to refuse to accept adoption if it was offered. The director, a strong advocate of racial matching, felt that an exception was warranted in these unusual circumstances, but noted that he had to do battle with forces within the state and agency bureaucracies in order to implement the transracial placement.

The director of another program with a specific focus on recruiting minority parents told me of one transracial adoption she had arranged. It involved. "John", a victim of fetal alcohol syndrome, who was mentally retarded. The director had held John for three years while she looked for a minority family by means that included listing him in a state-wide photo-listing register, or "exchange," of children available for adoption. When a white couple volunteered their interest in adopting John, the director described herself as having hesitated, but having finally agreed to see them. She eventually placed the child with them, finding herself very impressed by their parenting credentials and the fact that they already had children from a variety of ethnic backgrounds. Another director told me of a transracial placement she made in a case involving hard-to-place minority siblings. The only available minority family was interested in adopting one but not the other. Since the director felt separation would be disastrous for the children, she placed them with a white couple. As a result she was subjected to intense criticism and pressure from the local chapter of the NABSW.

\section{Recruitment}

There is general agreement among adoption workers that an affirmative effort should be made to recruit black families so that there will be more such families for the available black children, although the resources actually devoted to recruitment vary enormously. There have been some notable efforts to form organizations and adoption agencies under black leadership and to involve black churches and the media in the recruitment attempt. These efforts have had some success in encouraging black families 
to consider adoption and move through the adoption process. ${ }^{81}$ State, regional, and national exchanges of black and other "hard to place" children waiting for adoption have been created both as a means of making their availability more generally known, and as a way of recruiting parents not locally available. ${ }^{82}$

There is, of course, no systematic recruitment of white families for waiting black children, since matching policies preclude transracial placement except as a last resort. Nor is there generally any effort to recruit white families even for children for whom there seems little prospect of ever finding black adoptive families. Older black children with very serious mental or physical disabilities constitute a hardcore hard-to-place group. One leader in the world of "special needs" placement told me that she had recently begun to wonder if it would not be appropriate to recruit white as well as black parents, in the interest of finding homes for some of these children, but had run into nothing but opposition from her colleagues. ${ }^{88}$

Race-conscious recruitment and non-recruitment takes many forms. Agencies whose job is to find homes for minority children target their media and organizational efforts on minority communities. Adoption exchanges often specify with respect to the black children listed that the social worker is looking for a black family. ${ }^{84}$ "Sunday's Child" or "Wednesday's Child" advertisements that appear in newspapers and on television describing particular waiting children often contain similar specifications. And as indicated above, adoption workers may choose not to free minority children for adoption so that adoptive parents can be recruited, because of the dearth of minority families thought likely to be available.

81 See generally D. DAY, supra note 11, at 21-23.

82 See Adoption Opportunities Program, Title II, Pub. L. No. 95-266, 92 Stat. 208 (codified as amended at 42 U.S.C. $\$ \$ 5111-5115$ (1988)) (providing for the operation of a national adoption information exchange system, and the coordination of this system with similar state and regional systems).

${ }^{83}$ See Telephone interviews with Carolyn Johnson, Executive Director of the National Adoption Center, (Oct. 10, 1989 \& Feb. 12, 1991). Others I spoke with confirmed the fact that there is, as a general matter, no affirmative effort at any time to reach beyond the minority community to find homes for hard-to-place minority children.

84 The director of a national exchange for hard-to-place children told me that a racial preference is specified for most of the minority children listed in her exchange. Only in cases of some of the most severely disabled children are the listings not likely to specify such a preference. See Telephone interview with Peggy Soule, Director of the CAP Exchangebook (Oct. 10, 1989). 


\section{Subsidies}

Subsidies are very generally made available to minority couples and singles to enable and encourage them to adopt minority children. All states make some provision for subsidies to persons adopting certain "special needs" children. The federal government encourages such subsidies by providing states with federal funds to "match" qualifying state subsidies. ${ }^{85}$ Minority status alone puts children in the "special needs" category for federal law purposes, making them eligible for the subsidies so long as certain other conditions are met, $^{86}$ including state eligibility requirements. ${ }^{87}$ These subsidies are provided on an on-going basis until the child's maturity. ${ }^{88}$ Even though limited in amount, these subsidies ${ }^{89}$ are thought to have made a significant difference in encouraging large numbers of minority families to adopt.

Although white families are technically eligible for these subsidies, the fact that whites will rarely be allowed to adopt minority children means the subsidies operate primarily to facilitate inrace adoption. Indeed, it is clear that subsidy programs have been designed to a significant degree to further the goal of expanding the minority parent pool. The federal subsidy legislation is written in race-neutral language, which would seem to require that agencies make an effort to place children without regard to race with families

${ }^{85}$ The Federal subsidy program began with passage of the Adoption Assistance and Child Welfare Act of 1980, Pub. L. No. 96-272, 94 Stat. 500 (codified as amended at 42 U.S.C. $\$ \S 670-79 \mathrm{a}(1988)$ ).

${ }^{86}$ See 42 U.S.C. $\$ 673(\mathrm{c})(1988)$; id. § 673(a)(2)(A) \& (B). See generally Bussiere \& Segal, Adoption Assistance for Children with Special Needs, in ADOPTION LAW AND PRACTICE 9-6 to 9-19 (J. Hollinger ed. 1990).

87 See 42 U.S.C. \$ 673(c) (1988).

88 In addition, persons adopting; a minority race or other "special needs" child are eligible under federal law for a one-time-only direct subsidy for purposes of reimbursing the costs of the adoption in states with qualifying subsidy programs. The total subsidy is limited to a maximum of $\$ 2000$. The federal government is to reimburse the states for one-half the amount of qualifying subsidies paid out. See id. $\S 673(\mathrm{a}) ; 45$ C.F.R. $\$ \S 1356.41,1356.60$ (1990). However, only a few states appear to have instituted qualifying subsidy programs. See Interview with Betty Laning, Open Door Society, in Boston (Dec. 13, 1990).

${ }^{89}$ Adoption assistance benefits may include payment of non-recurring adoption expenses, medical assistance, social services, and cash payments up to the amount of the state foster care payment. See Bussiere \& Segal, supra note 86, at 9-19 to 9-32. In Massachusetts, the foster care "cap" on the cash payment is $\$ 410$ per month or $\$ 4982$ per year for a child 12 or under, and $\$ 486$ per month or $\$ 5913$ per year for a child over 12, in addition to which there is a clothing allowance. See Telephone interview with Nancy Rodriguez, Supervisor of Adoption Subsidy Program, Massachusetts Department of Social Services (Feb. 13, 1991). 
that can afford to adopt without subsidy, before the child can be qualified as a "special needs" child. ${ }^{90}$ However, the federal and related state subsidy programs are administered within the context of a general understanding that no such efforts are in fact required since it is only same-race placements that are considered appropriate.

\section{Differential criteria for assessing parental fitness}

Agencies apply significantly different parental screening criteria to prospective black adoptive parents than they do to prospective white adoptive parents in order to increase the prospects for inrace placement. In efforts to increase the number of black prospective parents, agencies reach out to include the kinds of people traditionally excluded from the white parent pool, or placed at the bottom of the waiting lists for children-singles, older people in their fifties and sixties, and people living on welfare, social security, or similar marginal incomes. ${ }^{91}$ Critics of transracial adoption have condemned the traditional screening criteria as discriminatory against the black family, and they feel that agencies have not moved nearly far enough to remove this kind of discrimination. ${ }^{92}$ They are quite right that traditional criteria, which emphasize economic stability, marriage, and middle class American values, do function disproportionately to disqualify blacks. They are also right that agencies have not abandoned their traditional criteria altogether in screening black applicants. Nonetheless, most agencies have either significantly softened or radically departed from their traditional criteria in considering black adoptive applicants.

As a result, the pool of black adoptive parents looks very different in socio-economic terms from the pool of white parents. Black adoptive parents are significantly older, poorer, and more

${ }^{90}$ Federal law specifies that children will be considered "special needs" children only if the state determines "that there exists . . . a specific factor or condition (such as his ethnic background ... or membership in a minority . . . group ...) because of which it is reasonable to conclude that such child cannot be placed with adoptive parents without providing adoption assistance, ... [ [and] that, except where it would be against the best interests of the child because of such factors as the existence of significant emotional ties with prospective adoptive parents while in the care of such parents as a foster child, a reasonable, but unsuccessfuh effort has been made to place the child with appropriate adoptive parents without providing adoption assistance under this section . . . " 42 U.S.C. $\S 673$ (c)(2) (1988) (emphasis added).

91 See A STUDY OF TRANSRACIAL AdOPTION, supra note 56, at 36-40.

92 See Preserving Black Families, supra note 43, at 34-36, 40-41. 
likely to be single than their white adoptive counterparts. A major study published in 1986 gives some indication of the differences. ${ }^{93}$ Fifty percent of minority adoptive families had incomes below $\$ 20,000$ per year, and twenty percent had incomes below $\$ 10,000$ per year. By contrast, only fourteen percent of non-minority families had incomes below $\$ 20,000$, and only two percent had incomes below $\$ 10,000 .{ }^{94}$ Forty-five percent of the fathers in the minority families were age forty-five or over, with fourteen percent age sixty-one or over. Only nineteen percent of the non-minority adoptive fathers were age forty-five or over and only two percent were age sixty-one or over. ${ }^{95}$ One study involving a small sample of adoptions reported that one-half of the black single parents involved earned less than $\$ 10,000 .{ }^{96}$ The former director of one of New York State's major adoption agencies told me agency policies in New York required that "just about anyone" of the minority race be considered eligible as an adoptive parent for minority children. ${ }^{97}$

It is important to note that in altering screening criteria for black adoptive families, adoption workers have by no means repudiated these criteria as irrelevant to determining parental fitness. Black and white parent candidates are still assessed and ranked by these criteria, with singles, older people, and economically marginal candidates placed at the bottom of the prospective parent lists. What adoption workers have done, in trying to expand what is an all-too-short black prospective parent list, is to seek out the kind of people they would normally exclude altogether from the white parent lists. Because of the importance attributed to the racial factor, those at the bottom of the black list are generally preferred over all those on the white list for any waiting black child. ${ }^{98}$

93 See WESTAT REPORT, supra note 56.

${ }^{4}$ See id. at 3-10, 3-13 to 3-15; see also Rosenberg, Despite Advances, Minority Children Lack Permanence, NAT'L ADOPTION REP., Jan.-Feb. 1987, at 3, 3-4. Rosenberg points out that the poverty level in 1986 for a family of four was defined as an annual income of $\$ 11,200$. See id.

${ }^{95}$ See WESTAT REPORT, supra note 56, at 3-16.

${ }^{96}$ See Shireman \& Johnson, A Longitudinal Study of Black Adoptions: Single Parent, Transracial and Traditionah 31 Soc. WORK 172, 172-73 (1986). Only 31 single parent placements were involved in the study.

${ }^{97}$ See Interviews, supra note 50 . She believed the policies to be mandated by state policies that require a strong inracial placement preference, and simultaneously forbid agencies from using traditional criteria to disqualify prospective parents unless those parents are demonstrably incapable of providing care.

98 The issue of differential standards does not ordinarily arise in the context of 


\section{THE IMPACT OF CURRENT POLICIES}

A major issue is the degree to which racial matching policies result in delaying or denying permanent placement for minority children. What we know is that minority children are disproportionately represented in the population of children waiting for adoptive homes, they spend longer waiting than white children, and they are less likely to be eventually placed. Estimates indicate that of the population of children waiting for homes, black children make up over one-third and children of color make up roughly onehalf. ${ }^{99}$ A recent study found that minority children waited for an average of two years, compared to an average one year wait for nonminorities. ${ }^{100}$ Minority placement rates were twenty percent lower than non-minority placement rates. The minority children were comparable in age with the non-minorities and had other characteristics which, had race not been an issue, should have made it easier to find adoptive placements-they had fewer disabilities and fewer previous placements in foster care. The study concluded that racial status was a more powerful determinant of placement rate than any other factor examined. ${ }^{101}$ These findings are consistent with the general understanding. ${ }^{102}$ They of course do not conclu-

a direct comparison between a minority and a white family because black children are placed in a separate pool, available in the first instance to minority families only. There is no effort to assess which available families, black or white, score highest in terms of parental fitness criteria and then decide how heavily the racial matching factor should weigh in the final placement decision. Instead, consideration is given only to the black family pool, at least until the supply of black families found to satisfy minimum standards of parental fitness is exhausted.

${ }^{99}$ See supra notes $10 \& 61$. By contrast, blacks make up $12.3 \%$ of the total population and people of color make up approximately $17 \%$. See U.S. DEP'T OF COMMERCE, STATISTICAL ABSTRACT OF THE UNITED STATES 1990, at 12 (1990).

${ }^{100}$ See WESTAT REPORT, supra note 56.

101 See WESTAT REPORT, supra note 56 , at $\mathrm{x}-\mathrm{xi}, 3-7$ to $3-8,3-17$ to $3-44,6-1$; see also Rosenberg, supra note 94, at 3 .

102 See Mason \& Williams, The Adoption of Minority Children, in ADOPTION of CHILDREN WITH SPECIAL NEEDS 83-84 (1985) (noting that minority children are disproportionately represented and spend longer in foster care than white children); NO PLACE TO CALL HOME, supra note 10, at 38-39. There is, however, some conflict in the findings regarding the connection between race and delay in placement. See Benedict \& White, Factors Associated with Foster Care Length of Stay, 70 CHILD WELFARE League J. Pol'y, PraC. \& Program 45, 48, 50 (Jan.-Feb. 1991).

Unfortunately the current APWA efforts to gather statistics on a systematic basis are not designed to assess the comparative length of stay in out-of-home placement for black and for white children. See Tatara Interview, supra note 10. However, the APWA statistics for 1987 do indicate that blacks leave out-of-home care at a lower rate than whites. Black children made up $37.1 \%$ of the children in care and $34.1 \%$ 
sively demonstrate a relationship between the problems minority children face in finding adoptive placements and the racial matching policies described in Part III. But it seems highly likely that there is significant linkage. Informed observers of the adoption scene-people who know the policies and see them in operationbelieve there is a strong causal connection between the policies and the delays and denial of placement that minority children face. ${ }^{103}$

The most adamant critics of transracial adoption argue that there are no good figures available on the children waiting for adoption. ${ }^{104}$ They say that even if minority children are particularly subject to delays and clenial in placement, the solution lies in devoting more resources to the preservation and the reunification of black biological families, and to the recruitment of minority families for those children who must be removed from their homes. ${ }^{105}$ They argue that with such efforts, black homes could be found for all waiting children. They argue further that whites would not be willing to adopt the minority children who wait,

of those legally free for adoption at the end of fiscal year 1987 (and 34.9\% of the children in care, and $42.4 \%$ of those legally free for adoption at the end of fiscal year 1986). They made up only $26.5 \%$ of the children who left care in fiscal year 1987 , and $27.7 \%$ of the children whose adoptions were finalized in 1987. See id.

${ }^{103}$ See Telephone interview with Ken Watson, Assistant Director of Chicago Child Care Society (Oct. 11, 1989). The Chicago Child Care Society is an adoption agency serving special needs and minority children. Mr. Watson is a member of the Child Welfare League of America Adoption Task Force and co-author of a longitudinal study comparing inracial with transracial adoptions.

A study done for the Child Welfare League provides implicit support for this conclusion. The study found a significant and disturbing "disjuncture" between the large number of minority children (51\% of the total) waiting for long periods for placement and the large number of white adoptive applicants waiting for long periods for children. The adoption agencies surveyed had cited the limited number of minority adoptive applicants as a major reason for the difficulty in arranging adoptions. The authors of the study argued that greater efforts be made to arrange matches between the waiting minority children and the waiting white parents. See J. MUNNS \& J. COPENHAVER, supra note 10 , at 4,18 . The numbers mismatch phenomenon, discussed supra note 62 and accompanying text, provides significant evidence that the reluctance to place transracially is responsible for delaying and denying placement to black childrien.

${ }^{104}$ It is true that the foster care figures may be somewhat misleading. As indicated supra note 59 , foster care is increasingly used as a form of quasi-permanent care. Children are placed with rnembers of their extended family or in other situations that allow some on-going relationship with their biological family. In some instances these arrangements represent a preference for preserving the child's biological family ties, rather than or in addition to a preference for same-race placement.

${ }^{105}$ See supra note 80. 
noting that most of the children in foster care are older and that they suffer from a variety of physical and emotional problems.

But the fact is that the resources devoted to the goal of preserving black biological families and to making inracial adoption work have been limited and are likely to be limited in the foreseeable future. There are and almost certainly will be for some period of time too few black families available for the waiting biack children. ${ }^{106}$ By contrast, there are many white families eagerly awaiting the opportunity to adopt. Although white adopters, like black adopters, tend to prefer healthy infants, special needs recruitment efforts in recent years have demonstrated that whites as well as blacks are often willing to adopt older children and children with devastating disabilities. ${ }^{107}$ Current racial matching policies stand in the way of tapping this ready resource of homes for minority children. Moreover, the reason that so many of the waiting black children are older is in part because matching policies have kept them on hold.

Although it seems clear that racial matching policies cause delays and denial in placement for minority children, it is harder to get a sense for how common and how lengthy the delays are and how frequently minority children are permanently denied adoptive homes. The consensus among adoption professionals seems to be that black homes can be found for healthy young black infants; most children falling into this category are being placed. However, their placement may still require a recruitment process of many months. If the agency is not engaged in active minority family recruiting, years may go by while the agency waits for a same-race family. ${ }^{108}$ For young black children who must be freed for adoption by court proceedings terminating parental rights, there will often be

${ }^{106}$ The socio-economic disadvantages of blacks as a group explain, to a significant degree, both the fact that disproportionate numbers of black children are living in out-of-home placements, and the fact that limited numbers of black families are available to adopt them. It is, for the most part, people living in relatively stable social and economic situations who have sought the opportunity to parent through adoption.

${ }^{107}$ Cf. WESTAT REPORT, supra note 56, at 3-14 to 3-15 (noting that a higher proportion of white than minority adoptive parents adopted children with disabilities).

${ }^{108}$ Many of those with whom I spoke indicated that despite claims often made that there is or should be no problem in placing black infants inracially, black infants often waited for placement for periods ranging from several months to several years, or longer. 
additional years of delay. ${ }^{109}$ While the months and years go by the children are pushed deeper into the hard-to-place category, as they get older and accumulate what are often damaging experiences in foster care. Delay thus puts the child at risk of yet more delay and, ultimately, the denial of placement altogether.

For children with severe disabilities and for older children, most of whom have some problems in addition to age that make them hard to place, the risks of lengthy delay and permanent denial of placement are even greater. Although agencies are generally somewhat more willing to consider transracial adoption for these children, they are still likely to treat it at best as a last-resort option to be considered only after minority families have been recruited and appropriate waiting periods exhausted. Accordingly, white adoptive parents are actively discouraged from finding out about or expressing interest in minority special needs children by the racespecific recruitment devices described above, ${ }^{110}$ and white parents' requests for consideration for specific minority children are often rebuffed.111 Equally significant is the fact, noted above, ${ }^{112}$ that recruitment has not been used in a positive way to encourage white parents to adopt hard-to-place minority children. The lesson of the last two decades, during which children with special needs have for the first time been placed in significant numbers, is that active recruitment together with the use of subsidies and a relaxation of traditional screening criteria is essential to the goal of finding homes for these children. With such

${ }^{109}$ See supra note 77 and accompanying text.

110 The exchange listings of waiting children contain many descriptions of teenage children with very severe handicaps and tragic lives-children born with spina bifida resulting in paralysis and a wheelchair existence, children with sther overwhelming disabilities, and children removed from their biological family because of serious abuse and then bounced from a succession of foster care homes. Often the last line of the description will read: "Social worker prefers black family."

111 The National Coalition To End Racism in America's Child Care System has filed a number of complaints with the United States Department of Health and Human Services charging a violation of Title VI of the 1964 Civil Rights Act on the basis of agency rejections of white adoptive applicants' requests to adopt hard-to-place minority children. One such complaint involved a charge that the New York Department of Social Services refused to consider a white couple as adoptive parents for a 10-year-old mixed race child listed in the CAP Exchange book solely because they were white (interestingly, the couple was already parents to two mixed race children). Although the couple expressed their on-going interest in being considered, they found the child still listed over two years later. See National Coalition to End Racism in America's Child Care System, The Children's Voice Newsletter (Nov. 1985).

112 See note 83-84 and accompanying text. 
recruitment it appears that homes can be found for even the most seriously disabled.

Conversations I had with the director of the National Adoption Center give some sense for how different aspects of the inrace preference policies work together to limit chances that minority special needs children will find permanent homes. Funded by the federal government, the Center sponsors the only major national exchange that lists both hard-to-place children and prospective parents. ${ }^{113}$ Agencies from around the country use the exchange to list children for whom they have been unable to find what they consider appropriate placements locally. Most of the minority children have therefore already been waiting for placement with a minority family for a significant period of time before they are placed on the exchange. The Center tries to match children listed on its exchange with appropriate parents who are on its list, and it also recruits parents in the minority community for the waiting minority children. The Center will not consider a transracial placement until a child has been listed on the exchange for six months. At that point, the Center might consider couples in which one member is of the same race as the child, or even a white family that specifically requested a particular minority child. But the Center makes no effort then or at any subsequent point to look for white families for waiting minority children. Even when the Center is willing to consider a transracial placement, the local agencies, which have formal custody of the children, often remain unwilling. The director described herself as a strong proponent of inracial placement, who believed transracial adoption should be considered only as a last resort. Nonetheless she revealed her concern with the delay children often experienced in getting listed on her exchange, with the reluctance to consider white families as an option even after a minority child had been listed for six months, and with the failure actively to recruit white families. ${ }^{114}$

We know that many minority children never receive adoptive homes, and many others spend years waiting in foster care or institutions. We know that while most prospective white adopters prefer to adopt healthy white infants, many are interested in adopting black children and many are interested in adopting older

113 The CAP Book is the other national exchange with information on children, but it does not list prospective parents.

114 See Telephone interviews with Carolyn Johnson, Executive Director, National Adoption Center (Oct. 10, 1989 \& Feb. 12, 1991). 
children with serious disabilities. There can be no doubt that the current racial matching regime, by barring and discouraging white parents from transracial adoptions, rather than welcoming them in the agency doors, denies adoptive homes to minority children. ${ }^{115}$

The racial matching policies also mean that black children who can be placed inracially go to families that are as a group significantly different in socio-economic terms from typical white adoptive families and rate significantly lower according to traditional parental screening criteria. ${ }^{116}$ Some are of course going to middle class black couples that look like the classic white adoptive family. But recruitment has never produced enough such couples for the minority children in need. As a result, black children are being placed, on a wholesale basis, with families for whom the limited subsidies available are a necessary precondition for adoption and with families that would be screened out by traditional criteria regarding economic and social stability.

The important question here is whether placements are being made on a frequent basis with families that should be seen as substandard or as significantly less fit to provide appropriate parenting than waiting white adoptive parents. The current system creates obvious pressures for such placements. Adoption workers unable to arrange a same-race match are left with a child for whom the official system provides no other acceptable alternative-longterm foster care and transracial adoption are both seen as system failures. Recruitment can be used to pressure people who have no genuine interest in parenting to adopt children for whom they are told no home is available. Subsidies can be used to encourage people who have very real financial needs but no real interest in a child to agree to an adoptive placement. ${ }^{117}$ Many of those I

115 Both the Child Welfare League and the National Committee For Adoption have recommended that children should not suffer undue delays or permanent denial in adoptive placement solely because of the inability to find a same-race placement. See supra notes 70-71. These recommendations appear to reflect conclusions by these informed observers of the adoption scene that current policies result in such delay and denial on more than a sporadic basis.

116 See supra text accompanying notes 91-98.

117 Cf. Brooklyn Woman and Boyfriend Charged in Sex Abuse of Four Sisters, N.Y. Times, Nov. 21, 1990, at B1, col. 3, B7, col. 1 (discussing a case in which a foster mother was charged with sexually abusing four girls in her care, revealing that she received subsidies of $\$ 385$ to $\$ 526$ per month per child, and calculating that the foster mother received a minimum of $\$ 23,544$ per year or $\$ 1962$ per month for care of the foster children); see also supra note 89 (noting the amounts involved in subsidies available for special needs adoptions). 
spoke to voiced their fears that racial matching policies had in fact produced, on a widespread basis, placements with families that were not capable of or interested in providing appropriate parentingfamilies that they characterized as substandard or unfit. ${ }^{118}$

It is true that traditional screening criteria are seriously flawed and based on a narrow vision of the ideal family form-the white middle class nuclear family of some mythical past. But we should not leap to substitute an idealized vision of the black family when dealing with black children. We should not romanticize about what it is like to live on the social and economic margins of society. It is one thing to argue, as I would, for the elimination of the traditional system for screening and rating parental fitness in favor of a system which looks to the motivation to parent as a primary indicator of parental fitness. I would be in favor of a system that established only minimum criteria for parental fitness for black and for white adopters and then relied on counselling to educate and socialize prospective adoptive parents. And I would be prepared to assume that those who push forward to pursue adoption under these circumstances will, as a general matter, be at least as committed and fit a parent group as non-adoptive parents, many of whom fall into parenting without any conscious choice whatsoever. But it is quite another thing to use financial inducements to recruit, as adoptive parents, people who may have no particular interest in parenting and whose social and economic circumstances make parenting extremely difficult, in a context in which the assumption is that the children have no other viable alternative.

\section{THE EMPIRICAL StUdies}

A number of research studies have attempted to assess how well transracial adoptions work from the viewpoint of the adoptees and their adoptive families, analyzing such factors as adoptee adjustment, self-esteem, racial identity, and integration into the family

${ }^{118}$ See generally Interviews, supra note 50. The former director of one of New York's major agencies expressed concern that New York's state matching policies resulted in the systematic placement of black children with families who were "so much older" and with families who were "so marginal." See Interviews, supra note 50. The former director of a major adoption agency in the Boston area spoke of one case in which a state agency placed a child for adoption with a family from which an adopted child had previously been removed on the grounds of sexual abuse by the father. See id. Cf. The Children's Voice Newsletter, supra note 72, at 1 (reporting on the death of a black child after transfer from a white foster family to a black foster family for racial matching reasons). 
and community. The nature of the studies that exist reflect a bias on the part of those responsible for funding, sponsoring, and conducting research. The early studies tend to look at transracial adoption as an exception to the accepted racial matching norm and ask questions as to whether the kinds of problems adoption professionals might anticipate have developed. The later studies tend to look at the claims made by the NABSW and other critics of transracial adoption to determine whether there is evidence to support their arguments that transracial adoptees will not develop "appropriate" racial identities or "survival skills." The general emphasis is thus on the potential negatives in transracial adoption. Few studies ask questions designed to assess the potentially positive aspects of transracial adoption. Almost none ask questions designed to assess the potentially negative aspects of current matching policies. As indicated above, there have been no systematic attempts to measure the degree to which racial matching policies result in delay in and denial of adoptive placement. There have been no systematic attempts to evaluate on a comparative basis the experience of children placed immediately with waiting white families to the experience of children held in foster or institutional care on a temporary or permanent basis for same-race placement. ${ }^{119}$ There have been no attempts to assess the experience of those black children placed inracially pursuant to current policies with the same critical approach used to assess the experience of those placed transracially.

Despite this bias in the design of the research, the studies provide an overwhelming endorsement of transracial adoption, as is described more fully below. ${ }^{120}$ The studies were conducted by

119 But see W. Feigelman \& A. Silverman, Chosen Children: New Patterns of ADOPTIVE RELATIONSHIPS 92-93 (1983) (comparing the significance of the race matching factor to the significance of delay in placement); Barth, Berry, Yoshikami, Goodfield \& Carson, Predicting Adoption Disruption, 33 Soc. WORK 227, 231 (1988) [hereinafter Predicting Disruption] (documenting benefits of permanent adoption and finding age at placement related to adoption disruption, but race difference between parent and child not related). Although these studies do not compare the experience of different control groups of children, they do provide very valuable information on the relevant issues. See infra text accompanying notes 165-66.

${ }^{120}$ See infra text accompanying notes 127-57; see also J. SHIREMAN, GROWING UP ADOPTED: AN EXAMINATION OF MAJOR IsSUES 24 (1988) [hereinafter GROWING UP ADOPTED] (describing all the major studies assessing transracial adoptees' general adjustment as agreeing on the conclusion that "transracially adopted children seem as well integrated into their families, seem to be doing as well in school, and seem in general to be as well adjusted as other adopted children"). 
a diverse group of researchers that included blacks and whites, critics and supporters of transracial adoption. With astounding uniformity their research shows transracial adoption working well from the viewpoint of the children and the adoptive families involved. The children are doing well in terms of such factors as achievement, adjustment, and self-esteem. They seem fully integrated in their families and communities, yet have developed strong senses of racial identity. They are doing well as compared to minority children adopted inracially and minority children raised by their biological parents.

This is not to say that the studies in themselves should resolve the debate about transracial adoption. ${ }^{121}$ The issue of how these adoptions and how current matching policies affect the welfare of children is only one piece of that debate. Another piece involves issues as to the values of preserving and promoting black families and black communities and black culture, and related issues as to the role of black political power and black nationalism. The studies provide some evidence that black children raised in white families tend to develop a different sense of their relationship to black and to white communities than black children raised in black families. ${ }^{122}$ How one reads this evidence depends largely on one's political perspective on these issues.

Nonetheless, most participants in the debate claim they are motivated largely or entirely by their concern with the welfare of the children at issue. The adoption professionals, the legislatures, and the courts which will jointly be responsible for resolving the debate are all bound by principles that require, in matters regarding children, enormous deference to "the best interest of the child."

Again, the studies do not definitively resolve the issue of what serves the children's interests. It may be that studies are incapable of measuring the value to a black child of being raised by black parents as part of a black community with a sense of its unique black cultural heritage. One can criticize the studies as relying unduly on the subjective views of the adoptive parents involved, or

${ }^{121}$ Nor is it to say that the studies demonstrate transracial adoption to be entirely free from problems or complications. Indeed, the studies document that parents often see these adoptions as difficult and challenging. See, e.g., R. MCROY \& L. ZURCHER, TRANSRACIAL AND INRACIAL ADOPTEES: THE ADOLESCENT YEARS 138 (1983) ("Most certainly transracial adoptive parents experience some challenges different from inracial adoptive parents, but in this study, all of the parents successfully met the challenges.").

122 See infra text accompanying notes $142-57 \& 167-69$. 
reflecting the value judgments of the researchers as to how to measure adjustment or racial identity, or how to establish indicators of adoptive success. ${ }^{123}$

But the studies constitute the only evidence we have as to what has actually happened when children are placed transracially. They are often relied on by critics of transracial placement, by legislators, by the media, ${ }^{124}$ and by courts ${ }^{125}$ as indicative of the problems for children inherent in such placement. The studies in fact provide no basis for concluding that placement of black children with white rather than black families has any negative impact on the children's welfare. The studies may not definitively prove anything, as few studies relating to the happiness of human beings do. But in a world of limited information, they provide persuasive evidence that transracial adoption serves the interests of children.

At the same time, there is no real need for comparative studies of the impact of current matching policies to know that these policies are likely to cause serious harm to minority children. We know that these policies regularly delay and often prevent permanent placement. To the degree we know anything in the child welfare world, we know this harms children. We have many studies and decades of professional experience demonstrating that continuity and stability in a child's family relationships are central to well-being, that permanent adoptive homes are far better for children than temporary foster homes, and that delay in adoptive placement reduces the chances for a successful adoptive adjustment. ${ }^{126}$

${ }^{123}$ The studies vary in quality and persuasiveness. Some are based on small numbers. Some rely solely on parent interviews. Some look only at transracial adoptees without any comparison to a control group of inracial adoptees. Indeed, it is difficult to establish control groups that are truly comparable. Nonetheless, several of the more recent studies are quite sophisticated. See, e.g., W. FEIGELMAN \& A. SILVERMAN, supra note 119 (using regression analysis to identify which factors appear to be related to adoptive success); R. SIMON \& H. ALTSTEIN, TRANSRACIAL ADOPTEES, supra note 11 (reporting on third stage of longitudinal study of group of transracial adoptees and their families). The degree to which the studies, taken as a group, have arrived at similar positive conclusions about the experience of transracial adoptees and their families is impressive.

124 See, e.g., Identily Crisis: When White Parents Adopt Black Babies, Race Often Divides, Wall St. J., Sept. 12, 1990, at 1, col. 1. (claiming that the studies on transracial adoption "show mixed results," that "without doubt, the transracial environment generates its own adjustment and identity issues," and that adjustment "can be painful and, often, unsuccessful").

125 See infra note 219 and accompanying text.

${ }^{126}$ See infra text accompanying notes 162-66. 
So the studies should be of at least great significance in resolving the debate about current policies. Below I will discuss the evidence they contain in more detail.

\section{A. The Evidence as to General Adjustment}

A number of studies have looked at transracial adoptees and their families and tried to assess adjustment or adoptive success by examining such factors as self-esteem, educational achievement, levels of satisfaction expressed by family members, behavioral problems, and adoption disruption. ${ }^{127}$ These studies consistently show transracial adoptees doing well according to the measures of successful adjustment chosen by the researchers. ${ }^{128}$ In many of

127 See Griffith \& Adams, Public Policy And Transracial Adoptions Of Black Children, in FAMILY, CULTURE, AND PSYCHOBIOLOGY (forthcoming 1991) (summarizing the relevant studies and the debate about transracial adoption).

128 See Predicting Dismuption, supra note 119, at 228 (finding transracial adoptions no more likely to disrupt than other adoptions, confirming earlier studies); R. BARTH \& M. BERRY, ADOPTION AND DISRUPTION 78, 118, 216 (1988) (same); W. FEIGELMAN \& A. SIlvERMAN, supra note 119 , at $82-120$ (finding transracial adoption has no negative impact on adjustment); L. GROW \& D. SHAPIRO, BLACK CHILDREN-WHITE PARENTS: A STUDY OF TRANSRACIAL ADOPTION 224-26 (1974) (revealing results of major three year study commissioned by the Child Welfare League and coming to positive conclusions about transracial adoptees' adjustment as measured by such factors as behavior and teacher evaluations); J. LADNER, supra note 29, at xii, 249 (concluding, contrary to researcher's own initial skepticism, that "the data are unanimous in reporting that up to this point, the children and their parents are adjusting quite well," but emphasizing that problems may develop as the children grow older); McRoy, Zurcher, Lauderdale \& Anderson, Self-Esteem and Racial Identity in Transracial and Inracial Adoptees, 27 SOC. WORK 522, 524-26 (1982) [hereinafter Self-Esteem] (finding that the self-esteem of transracial adoptees is comparable to that of inracial adoptees and to norms in general population and not negatively affected by transracial placement); R. MCROY \& L. ZURCHER, supra note 121, at 28-116 (finding that transracial adoptees successfully integrated into adoptive families and communities); GROWING UP ADOPTED, supra note 120, at 35-38 (reporting on fourth phase of Chicago Child Care Society longitudinal adoption study and concluding that the transracially adopted children were generally doing well in terms of classic measures of adjustment and that their scores on such measures were generally comparable with those of inracial adoptees and of children raised by their biological parents); Shireman \& Johnson, supra note 96, at 172-96 (reporting similar conclusions at earlier stage of same Chicago Child Care study); R. SIMON \& H. ALTSTEIN, TRANSRACIAL ADOPTION I, supra note 11, R. SIMON \& H. ALSTEIN, TRANSRACLAL ADOPTION II, supra note 11, and R. SIMON \& H. ALSTEIN, TRANSRACIAL ADOPTEES, supra note 11 (reporting on three phases, one phase per book, of a major longitudinal study of transracial adoptees and painting a very positive picture of their adjustment and development at each stage, in terms of such factors as self-esteem and family relationships); Womack \& Fulton, Transracial Adoption and the Black Preschool Child, 20 J. AM. ACAD. CHILD PSYCHLATRY 712, 723 (1981) (finding that "the 28 [transracial adoption] children were doing well socially and developmentally"); C. ZASTROW, 
these studies the transracial adoptees are compared to control groups of black inracial adoptees; in others they are compared to black children raised in their biological families or to white children raised in white adoptive or biological families. Other studies focus in the first instance on study samples that include inracial as well as transracial adoptees and analyze the degree to which the racial matching factor appears to be related to adoptive success. All of these comparative studies show transracial adoptees doing generally as well as the other groups of children in terms of various traditional measures of social adjustment. ${ }^{129}$

Despite the positive findings, there is often a cautious and negative tone to the researchers' characterizations. Many of the studies emphasize that although the evidence looks positive so far, problems may well show up as the transracial adoptees reach some later stage of development. The early studies focused on adolescence as the point when the anticipated problems might manifest themselves. But as successive studies have followed the children through adolescence and into early adulthood, they find that the children continue to feel good about themselves, to enjoy good relationships with their families, and to do well in the outside world.

Three of the most significant of these recent studies are those conducted by McRoy and colleagues, by Shireman and colleagues

Outcome of Black ChILdREN-White Parent TransRacial Adoptions 86 (1977) (comparing transracial adoptive families with white inracial adoptive families and finding comparable success ratings); see also O. GILL \& B. JACKSON, ADOPTION AND RACE (1983) (finding, in a study of transracial adoption in Great Britain, involving black, Asian, and mixed race children, no particular problems in terms of self-esteem, family relationships, or behavior issues and concluding that these adoptions are comparable to other adoptions in terms of classic measures of adoptive success); $W$. FEIGELMAN \& A. SilverMAN, supra note 119, at 88 (reviewing some additional earlier studies and concluding that all the studies that look at transracial adoptees' general adjustment rates find that approximately $75 \%$ adjust well in their adoptive homes, a figure that is similar to the adjustment rates of other adoptees).

Feigelman and Silverman cite one early study as indicating potential problems with transracial adoption, with the white parents anticipating problems in school and the community. See W. FEIGELMAN \& A. SILVERMAN, supra note 119, at 89 (citing Falk, A Comparative Study of Transracial and Inracial Adoptions, 49 CHILD WELFARE 82 (1970)).

129 See Womack \& Fulton, supra note 128, at 712-23; W. FEIGELMAN \& A. SILVERMAN, supra note 119, at 88; Predicting Disruption, supra note 119, at 227; Selfesteem, supra note 128, at 525; Shireman \& Johnson, supra note 96, at 173; GROWING UP ADOPTED, supra note 120, at 35-38; L. GROW \& D. SHAPIRO, supra note 128, at 224-25; C. ZASTROW, supra note 12B, at 86 . The three transracial adoption books by Simon and Altstein focus mainly on the transracial adoptees, but draw some comparisons with white children born or adopted into the same families and find the transracial adoptees doing as well. 
in conjunction with the Chicago Child Care Society, and by Simon and Altstein. ${ }^{130}$ The McRoy study compared a group of black adolescents adopted by white families to a group of black adolescents adopted by black families. There was rough comparability between the two groups in terms of such factors as age at placement and socio-economic level, with some differences in parents' education and employment levels. The study focused initially on the development of self-esteem, in part because the critics of transracial adoption had argued that the adoptees would experience problems in this area. The researchers concluded:

This exploratory study indicated that there were no differences in overall self-esteem between the sampled transracially and inracially adopted children. Furthermore, the level of self-esteem of the adoptees was as high as that reported among individuals in the general population. This suggests that positive self-esteem can be generated as effectively among black children in white adoptive families as in black adoptive families. ${ }^{131}$

The Chicago Child Care Society has followed a small cohort of black children since the 1970s, comparing those placed transracially with those placed inracially as well as with black children raised in their biological families. The most recent of several follow-up reports, published in $1988,{ }^{132}$ looks at the children in their teen years and concludes that the transracial adoptees are generally doing well and are generally doing comparably with the other adoptees and with the non-adopted children. ${ }^{133}$ The report also

${ }^{130}$ See supra note 128.

${ }^{131}$ Self-Esteem, supra note 128 , at 525. In this and later reports, McRoy and colleagues raise questions about whether transracial adoptees are developing what they would see as "appropriate" racial identities, but they consistently describe the children as feeling good about themselves and functioning well in their families and communities. The final chapter of their 1983 book, Transracial and Inracial Adoptees, opens with the following conclusions:

The transracial and inracial adoptees in the authors' study were physically healthy and exhibited typical adolescent relationships with their parents, siblings, teachers, and peers. Similarly, regardless of the race of their adoptive parents, they reflected positive feelings of self-regard. Throughout the book, the authors have shown that the quality of parenting is more important than whether the black child has been inracially or transracially adopted.

R. MCROY \& L. ZURCHER, supra note 121, at 138.

132 See GROWING UP ADOPTED, supra note 120 (looking at overall adjustment, family relationships, peer relations, gender identity, school performance, and selfesteem).

133 The report notes that there are some apparent differences between the groups, 
assesses the way in which the adoptive families are functioning, concluding that for transracial families as for other adoptive families, "[ $t]$ he data of this study fit the common pattern of other research ... in showing family systems which have accepted the adopted child and are functioning well." 134

Simon and Altstein have conducted the major longitudinal study of transracial adoptees, reporting in three different books the results of the three phases of their study, with the most recent published in 1987. ${ }^{135}$ They followed a group of white families who had adopted black and other minority children, looking at both the minority adoptees and their white adopted and non-adopted siblings. The 1987 report finds the children in adolescence, with most in their last two years of high school. It looks at the longrange impact of transracial adoption on the black adoptees and on their white siblings. Simon and Altstein begin by summing up previous relevant research:

A belief that transracial adoption (TRA) is unnatural and therefore "bound to be unsuccessful" continues to be popular among many child welfare professionals. Many adoption officials claim that there are studies that indicate that TRA is too fragile an experience not to result in serious problems once the [transracial adoptees] leave their families. But to this date no data have been presented that support the belief that in the long run TRA is detrimental to those involved: the transracial adoptees, the adoptive parents, or the siblings. On the contrary, evidence accumulated by us and other researchers over more than a decade of investigating the effects of TRA indicates positive results. ${ }^{136}$

The 1987 report contains important new findings related to family integration and commitment. It finds the transracial adoptees as

but also offers explanations for some of those differences. The transracially adopted boys appeared to have more school problems than other groups, but also a disproportionate number of learning disabilities related to pre-adoptive physical or social history. See id. at 18-21. Transracially adopted boys scored more positively than other groups on certain measures.

${ }^{134}$ Id. at 34 . The report notes some grandparent resistance to transracial adoptions, but emphasized ways in which the transracial family systems seem unusually strong. The white parents seemed more comfortable discussing adoption with their children, and, interestingly, they perceived more similarities between themselves and their black children than did the black parents. See id. at 28-34.

${ }^{135}$ See R. Simon \& H. AltSTEIN, TRANSRACLAL AdOPTION I, supra note 11; R. Simon \& H. Altstein, TransRacial Adoption II, supra note $11 ; \mathrm{R}$. Simon \& $\mathrm{H}$. ALTSTEIN, TRANSRACIAL ADOPTEES, supra note 11.

${ }^{136}$ R. Simon \& H. ALTSTEIN, TRANSRAcial ADOPTEES, supra note 11 , at 3 (footnotes omitted). 
fully integrated into their immediate and extended families as the white adopted and white biological children:

$[P]$ erhaps the most important finding emerging from this latest survey is the sense of belonging felt by the [transracial adoptees] to their adopted families-the mothers and fathers are their parents, and the brothers and sisters, their siblings; they are not viewed as substitutes or proxies for "real" parents or "real" family.

[The data] fail to reveal any differences among the [different categories of children within the TRA families.] The [transracial adoptees] perceive themselves as having the same type of relationship with their family as the other children.

[I]n their relations with extended family members, the transracial adoptees define themselves as having at least as close ties with their relatives as the children born into the families. ${ }^{137}$

This report found no significant differences in self-esteem between the transracial adoptees and the other children, again confirming earlier research. ${ }^{138}$

Simon and Altstein's description of the great majority of the transracial families is extremely positive, consistent with the basic findings of their earlier reports:

We believe that the portrait that emerges is a positive, warm, integrated picture that shows parents and children who feel good about themselves and about their relationships with each other. On the issue of transracial adoption, almost all of the parents would do it again and would recommend it to other families. They believe that they and the children born to them have benefitted from their experiences. Their birth children have developed insight, sensitivity, and a tolerance that they could not have acquired in the ordinary course of life. Their transracial adoptees may have been spared years in foster homes or institutions. They have had the comfort and security of loving parents and siblings who have provided them with a good home, education and cultural opportunities, and the belief that they are wanted. ${ }^{139}$

137 Id. at $69,71 \& 75$.

138 See id. at 79.

139 Id. at 108-09. The report characterized a minority of the families included in this phase of the study-18 of 96-as "experiencing serious problems." Id. at 106. This percentage is typical of the percentage of troubled families found in studies of all adoptive families. Simon and Altstein indicated likely non-racial explanations for the special problems in many of the troubled families in their study. For example, 
Simon and Altstein note that "the children seem even more committed to their adoptive parents than the other way around. For the children, even during these sensitive, complicated years of adolescence, their adoptive parents are the only family they have and the only set of parents they want."140

In their final chapter Simon and Altstein sum up the significance of this latest phase of their study:

At the end of both the 1972 and 1979 studies, we emphasized the tentativeness of our conclusions. While focusing on the positive experiences that we were able to report, we also stressed how young the children were and how many difficult periods lay ahead. This time, we believe that the families have reached a different stage. . . The families have weathered the most difficult years of child rearing, and the large majority have come through the experience committed to each other and intact. ${ }^{141}$

\section{B. The Evidence as to Racial Attitudes}

The research evidence does indicate some significant differences between black children raised inracially and the transracial adoptees in connection with attitudes about race and race relations. Some of the researchers interpret this evidence as problematic, and they rely on it in drawing relatively negative or cautious conclusions regarding some aspects of transracial adoption. Critics of transracial adoption cite this evidence and these conclusions as supportive of their position.

But conclusions that this evidence is positive or negative in its implications for transracial adoption depends entirely on one's political perspective. From the perspective of one who believes that blacks and whites should be learning to live compatibly in one world, with respect and concern for each other, with appreciation for their racial and cultural differences as well as their common humanity, the evidence is positively heartwarming. And there is no

they note that in 7 of the 18 cases:

The children were all adopted when they were at least 4 years old and had serious mental and/or physical handicaps at the time. They had lived in foster homes or public institutions prior to their adoption. The parents, with one exception, emphasized that in their view race was not the source of the child's difficulties.

Id.

${ }^{140} \mathrm{Id}$. at 140.

${ }^{141}$ Id. at $140-41$. 
evidence that the differences in racial attitudes have any negative bearing on the welfare of the transracial adoptees themselves.

The evidence shows clearly that transracial adoptees develop a strong sense of black identity, contrary to many of the claims made about the evidence. Questions on this issue were raised by some of the earlier research that relied on anecdotal descriptions of certain transracial adoptees who allegedly over-identified with their white families. ${ }^{142}$ But more sophisticated comparative research indicates that transracial adoptees have essentially as strong a sense of black identity and racial pride as other minority children. ${ }^{143}$ Indeed, some of the evidence indicates that transracial adoption may even have a positive impact in terms of black children's sense of comfort with their racial identity. Simon and Altstein's research on transracial adoptive families was the first study finding minority children not showing a white racial preference or bias. ${ }^{144}$ The Chicago Child Care Society's longitudinal study shows transracial adoptees developing a strong sense of black identity and racial pride $^{145}$ and feeling more comfortable than the inracial adoptees with other black Americans. ${ }^{146}$

142 See J. LADNER, supra note 29, at 152. The author's general conclusions about transracial adoption were nonetheless quite positive. See id. See also L. GROW \& D. SHAPIRO, supra note 128, at 181-99 (indicating that some transracial adoptees had negative feelings about blackness, but noting there was no comparison group of black adoptees and, thus, no indication as to comparative feelings about blackness).

143 See generally Womack \& Fulton, supra note 128, at 722 (finding "no significant difference in racial attitudes between the transracially adopted black children and the nonadopted black children" and no indication that transracial adoption predisposes black adoptees to "any obviously negative or antiblack attitude[s]").

144 See R. Simon \& H. AltSTEIN, TRANSRAGIAL ADOPTEES, supra note 11, at 27-28.

The authors note:

The most important finding to emerge from our first study was the absence of a white racial preference or bias on the part of the white and non-white children. Contrary to other findings that had thus far been reported, the children reared in these homes appeared indifferent to the advantages of being white, but aware of and comfortable with the racial identity imposed on them by their outward appearance.

Id. See also id. at 112-13 (describing in detail the methods and results of the study).

${ }^{145}$ See GROWING UP ADOPTED, supra note 128, at 25 (noting that a greater percentage of transracial adoptees develop a sense of black identity and black preference than the inracial adoptees at age four, with the inracial adoptees catching up at early adolescence).

${ }^{146}$ See id. at 27 . Shireman observes that " $[t]$ hese ... measures . . . seem to give some assurance that these transracially adopted adolescents have developed pride in being black, and are comfortable in interaction with both black and white races." Id. 
The main difference revealed by the evidence is that transracial adoptees appear more positive than blacks raised inracially about relationships with whites, rnore comfortable in those relationships, and more interested in a racially integrated lifestyle. ${ }^{147}$ There is also evidence that they think race is not the most important factor in defining who they are or who their friends should be. ${ }^{148}$ Studies have found some transracial adoptees describing themselves as biracial or American or "human", rather than black. Most of them are, incidentally, genetically biracial and relatively light rather than dark-skinned, as these are the kind of "black" children that have generally been placed transracially. ${ }^{149}$

These kinds of self-descriptions, together with the transracial adoptees' sense of comfort in the white world, are seen as evidence of inappropriate racial attitudes by the critics of transracial adoption. ${ }^{150}$ Simon and Altstein, by contrast, voice the positive implications they see inherent in this kind of evidence. They describe the transracial adoptees as perceiving "their world as essentially pluralistic and multicolored". ${ }^{151}$ They conclude:

[T] he transracially adopted children[] represent a different and special cohort, one socialized in two worlds and therefore perhaps better prepared to operate in both. The hope is that having had this unique racial experience, they will have gained a greater sense of security about who they are and will be better able to negotiate

${ }^{147}$ See GROWING UP ADOPTED, supra note 128, at 27; R. SIMON \& H. ALTSTEIN, TRANSRACIAL. ADOPTEES, supta note 11, at 59-68, 80-83.

148 See, e.g., R. SimON \& H. AlTstein, TRANSRACIAL ADOPTEEs supra note 11, at 59$68,80-82$ (finding that transracial adoptees' personal interests, relationships, and plans for adulthood were often not race-based); R. MCROX \& L. ZURCHER, supra note 121, at 126-28 (noting that transracial adoptees referred to their background as mixed, part white, black-white, etc., while inracial adoptees "typically referred to themselves as being black").

${ }^{149}$ See supra note 14.

150 See R. MCROY \& L. ZURCHER, supra note 121, at 140. See generally id. at 124-49. This study noted that many of the transracial adoptees described themselves as "mixed, part white, black-white, human, or American." Id. at 127. The transracial adoptees were in fact more often of mixed racial heritage than the inracial adoptees to which they were compared. See $i d$. at 126-27. The researchers found that the transracial adoptees were more likely to identify themselves in racial terms than the inracial adoptees and had as healthy a sense of self-esteem. Nonetheless, the researchers came to relatively negative conclusions based on their sense that at least some of the transracial adoptees were developing inappropriate racial identities and attitudes. See id. at 140-41; see also Self-Esteem, supra note 128, at 524-26 (describing similar results); McRoy, Zurcher, Lauderdale \& Anderson, The Identity of Transracial Adoptees, 65 SOC. CASEWORK 34, 36-39 (1984) (same).

${ }^{151}$ SIMON \& ALSTEIN, TRANSRACIAL ADOPTEES, supra note 11, at 82. 
in the worlds of both their biological inheritance and their socialization. ${ }^{152}$

The latest report on the Chicago Child Care Society's longitudinal study finds similar implications in the evidence:

As far as we can tell with our measures, there has developed a positive black self image, combined with a mixed black white pattern of social interaction. It seems to us that this pattern may be one which will allow these young people to move with equal comfort in both black and white worlds, allowing them to cull what they wish from each culture, and perhaps creating bridges which will be of use to an even wider world. ${ }^{153}$

The fact that there are some differences in the racial attitudes developed by transracial adoptees is not surprising. It is completely consistent with what one would expect from the evidence as to general adjustment described above. These children have grown up in white families who tend to live in either relatively white or integrated communities. The adjustment evidence indicates that the children have felt a comfortable part of their white families and have flourished in what have been significantly white worlds. It is understandable that they will have developed a sense of the meaning of race that is very different from that of black children living in a state of relative isolation or exclusion from the white world.

This evidence is understandably problematic from a black separatist or nationalist perspective. One of the claims made by the critics of transracial adoption is that it prevents black children from developing the survival skills necessary for life in a racist societyskills they say can only be fostered by black parents who have themselves developed those skills. Although the evidence shows the transracial adoptees appear to be surviving very well, it could be argued that they have developed a naive and dangerous faith in their ability to get along in the white world, a faith that will serve them badly as they grow into the challenges of adulthood. In addition, blacks who believe their group interests will be advanced by building a politically and otherwise powerful black community are likely to find cause for concern in the evidence that black children raised in white families are growing up to feel comfortable in the white community. The president of the NABSW wrote in the association's Spring 1988 newsletter:

$152 I d$. at 10.

153 GROWING UP ADOPTED, supra note 128, at 36-37. 
The lateral transfer of our children to white families is not in our best interest. Having white families raise our children to be white is at least a hostile gesture toward us as a people and at best the ultimate gesture of disrespect for our heritage as African people....

It is their aim to raise Black children with white minds. ... ... We are on the right side of the transracial adoption issue. Our children are our future. ${ }^{154}$

The studies indicate that white families vary significantly in the degree to which they engage in deliberate socialization efforts to make their black children feel part of a black cultural community and proud of a black heritage. Such efforts do seem to have an effect in producing a greater sense of race interest and race pride. ${ }^{155}$ But there is no evidence that black parents do a better job than white parents of raising black children with a sense of pride in their racial culture and heritage.

Nor is there any evidence that such differences as may exist in racial attitudes have any negative implications on the well-being of those raised transracially. The studies that have examined racial attitudes have found no relationship between measures of racial identity or racial integration of the child's social setting on the one hand, and measures of self-esteem or general adjustment on the other. ${ }^{156}$ Feigelman and Silverman's report on their major comparative study of transracial adoptees concludes:

It seems obviously desirable ... to foster the development of a sense of racial pride and. identification. Such attributes would seem to be valuable for the development of self-esteem and optimal psychological functioning. Yet, we were unable to find any connection between the possession of black self-identification at 1,2 .

${ }^{154}$ Jeff, President's Message, NAT'L A. BLACK SOC. WORRERS NEWSL., Spring 1988,

155 See W. Feigelman \& A. Silverman, supra note 119, at 106-07, 109.

156 See id. at 104-06, 116, 118-19. This comparative study of black children adopted by whites with white children adopted by whites finds transracial adoptees adjusting well and finds no linkage between adjustment and racial identity measures. See id. at 118; see also Self-Esteenb supra note 128, at 524 (finding no statistically significant relationship between self-esteem scores and either childrens' perception of racial identity or racial composition of community or school); GROWING UP ADOPTED, supra note 128, at 27 (finding that transracial adoptees' social distance test scores indicate they are comfortable in interacting with both blacks and whites). See genetally R. SIMON \& H. ALTSTEIN, TRANSRACIAL ADOPTEES, supra note 11, at 112 (finding that transracial adoptees rated comparably with white birth and white adopted children on self-esteem scores). 
and a variety of indicators suggesting optimal social and psychological adaptation.

... It is entirely possible that these represent independent dimensions of social and psychological life. It may be that a transracial adoptee can be well-adjusted and identified with the black community, white society, or both. ${ }^{157}$

\section{The Evidence as to Advantages for Children of Transracial Placement}

As noted above, the great body of research on transracial adoption has been structured to look for its negative and not its positive potential. But there is every reason to think there are advantages for children inherent in growing up in a transracial, transcultural family setting. Existing studies necessarily contain only fragmentary hints of what might be found if anyone chose to look for such possible advantages.

A concededly limited and informal study of the children of interracial marriage conducted by Dr. Alvin Poussaint is illuminating. ${ }^{158}$ Dr. Poussaint interviewed a number of people who had grown up in families with one black and one white parent, inquiring specifically into their views as to positive as well as negative aspects of their biracial upbringing. He found that they tended to discount the alleged disadvantages inherent in their situation and to emphasize advantages. Among the advantages cited were the following: They felt they had access to two cultures and that being bicultural was a plus; they could move easily in both worlds and have different kinds of friends; some felt they were less intimidated in the white world than other black or biracial children; they felt they stood out as special in social situations in ways that were positive as well as negative; and they felt they had developed an unusually broad outlook and were more tolerant of differences. When asked if they would consider interracial marriage themselves and if they would feel comfortable raising a biracial child, they all answered yes. Although the situation of transracial adoptees of

157 W. FEIGELMAN AND A. SILVERMAN, supra note 119, at 118-19.

158 See Interview with Dr. Alvin Poussaint, in Boston (Jan. 15, 1991). Dr. Poussaint described himself as having conducted this interview study out of his own frustration at the uninformed negativity expressed at the time with regard to the impact of interracial marriage on the children involved. See id.; see also Poussaint, Study of Interracial Children Presents Positive Picture, 15 INTERRACIAL BOOKS FOR CHILDREN BuLl. 9, 9-10 (1984) (describing the study discussed in the text). 
course differs from that of these children in important respects, it seems likely that transracial adoptees, if asked, would have their own list of advantages to discuss.

Critics of transracial adoption have claimed that only blacks can teach black children the coping skills needed for life in a racist society, but there seems at least as good an argument for the proposition that whites are in the best position to teach black children how to maneuver in the white worlds of power and privilege. Indeed, it seems clear that for black children growing up in a white-dominated world, there would be a range of material advantages associated with having white parents and living in the largely white and relatively privileged world that such parents tend to frequent. ${ }^{159}$

159 There is, for example, some evidence that transracial adoption has a positive impact on certain classic measures of intelligence and intellectual achievement. These measures can, of course, be challenged as culturally biased. But the point is that blacks raised by whites are likely to get the "coping skills" needed for many aspects of life in a society that has been significantly dominated by whites. Studies that have looked at I.Q. development and scholastic achievement in black children raised in white families, with a view to assessing the role environment plays in the relatively low scores ordinarily achieved by black children, have found transracial adoption a significant positive influence. See Scarr \& Weinberg, IQ Test Performance of Black Children Adopted by White Families, 31 AM. PsychOLOGIST 726, 737-38 (1976) (finding I.Q. and school performance of black children with educationally average biological parents, adopted by advantaged white parents, above mean of black children raised in biological families and of white child population); Womack \& Fulton, supra note 128, at 719-20 (analyzing and comparing I.Q. and other development measures of black children adopted transracially and non-adopted black children, finding transracial adoptees' I.Q. scores higher than the non-adopted group, one standard deviation above the mean of the white population, and as much as two standard deviations above the mean score that is often reported for blacks); see also L. GROW $\&$ D. SHAPIRO, supra note 128 (showing high I.Q. and school achievement scores for transracial adoptees as compared to white population mean); L. GROW, TRANSRACLAL ADOPTION TODAY (1975) (same).

One study compared black children adopted by middle class white families with black children adopted by middle class black families. It found that transracial adoptees did significantly better on various intelligence measures than the inracial adoptees. The study concluded that the transracial adoptees' immersion in white culture in the context of family and community was responsible for their success. See Moore, Family Socialization and the IQ Test Performance of Traditionally and Transracially Adopted Black Children, 22 DEVELOPMENTAL PSYCHOLOGY 317, 325 (1986) ("The results from this study indicate that the ethnicity of the rearing environment, not just socioeconomic status and maternal education level, exerts a significant influence on children's styles of responding to standardized intelligence tests and their test achievement."). There were some differences in socio-economic measures between the black and the white families, but differences were limited, and although Moore indicates that they could have influenced the results, they did not affect her conclusions. See id.; see also Moore, Ethnic Social Milieu and Black Children's 
There could be other, less material advantages for adoptees growing up in a transracial family, along the lines that Dr. Poussaint found in his study of biracial children. For example, it could be an advantage to enjoy the kind of comfort in both black and white worlds that the studies discussed above indicate transracial adoptees feel. It could also be an advantage for an adoptee to grow up in a family that is so obviously not fashioned in imitation of the biological model. Studies indicate that transracial adoptive parents are more open in discussing adoption with their children and that the children are more likely to identify themselves as adopted. ${ }^{160}$ These findings raise the interesting possibility that, in transracial adoptive families, the unblinkable difference of race may encourage a healthier acceptance of the fact that their family is in various other ways not the same as a biological family. ${ }^{161}$

\section{The Evidence as to Costs for Children of Current Inrace Placement Preferences}

There is a fair amount of evidence, and a strong consensus, on the costs to children of delays in adoptive placement and in permanent denial of an adoptive home. Child welfare professionals agree with virtual unanimity that children need continuity in the context of a permanent home in order to flourish. ${ }^{162}$ There is a

Intelligence Test Achievement, 56 J. NEGRO EDUC. 44, 50-51 (1987) (reporting on data that "suggest that it is not just the ethnicity of the family of rearing that influences the development of the child's skills, attitudes, and problem-solving orientations, but also the ethnic milieu which surrounds the family," notably the transracial adoptees' exposure to white social structures).

${ }^{160}$ See R. MCROY \& L. ZURCHER, supra note 121, at 128-29; GROWING UP ADOPTED, supra note 128, at 31-32.

161 The author of the latest report on the Chicago Child Care Society's longitudinal study speculates on this positive potential in the race difference:

All of the transracially adopted children were told of their adoption early; communication about this has been open in these families. . . Recognition of differences, and maintenance of some distance between parents and child, may be associated with constructive handling of adoption. ... .

There is, one is sure, a link between perception of similarity, "claiming" an adopted child as part of the family [as the study found transracial adoptive parents did to an unusual degree], and being able to discuss adoption comfortably. Perhaps the link is the acknowledgment of the different nature of the adopted family, an acknowledgment that the transracially adopting family makes more easily than any of the other types of families in our study.

GROWING UP ADOPTED, supra note 128, at 31-32.

162 See, e.g., W. FEIGELMAN \& A. SILVERMAN, supra note 119, at 92 (noting that the experts in child development see continuity and stability in a child's environment as 
significant body of studies demonstrating that children do better in adoption than in foster care, ${ }^{163}$ and that age at placement in an adoptive family is a central factor in determining just how well adoptees will do in terms of various measures of adjustment. ${ }^{164}$

Moreover, to the degree that research studies have attempted to address the issue of whether delay in placement or racial match is a more significant factor in adoptive adjustment, they have found delay to be the key factor. Feigelman and Silverman did research that was specifically designed to answer the question whether "race difference and racial isolation in an alien community pose a more potent determinant for a child's adoptive adjustment than the discontinuities and hazards associated with delayed placement. ${ }^{p 165}$ In their study involving both black and white children placed with white parents, they found age at time of placement by far the most significant factor in explaining variations in adjustment measures. They concluded:

The data ... suggest that the deleterious consequences of delayed placement are far more serious than those of transracial adoption. The findings imply that when a choice must be made between transracial placement and continued foster or institution-

essential, and the "absence of a stable and enduring parental relationship ... as devastating and traumatic to a child's development"). Reference to the vast body of research supporting these propositions is made in Perry, supra note 17, at 72-73 nn.74-82.

${ }^{163}$ See, e.g., R. BARTH \& M. BERRY, supra note 119, at 23-41 (discussing the evidence and documenting the advantages of adoption over foster care). See generally Note, Racial Matching and the Adoption Dilemma: Altermatives for the Hard to Place, 17 J. FAM. L. 333, 356-58 (1979) (discussing evidence regarding harm from foster and institutional care).

164 Feigelman and Silverman sum up the evidence as follows:

The desirability of early, permanent placement is generally accepted as axiomatic within the social work profession .... It is well documented by Alfred Kadushin that the later the child is placed, the more serious and lasting the adjustment problems that accompany adoption. In David Fanshel's study . . . of Native American children adopted by white families, he found that a child's adjustment was negatively correlated with age at placement. His research also indicates why delayed placement may be so significant for the child's ultimate well-being. Not only is it a matter of disruption and discontinuity but, with delayed placement, the child is more likely to suffer from a hazardous environment.

W. FeIGelmaN \& A. Silverman, supra note 119, at 92-93 (citations omitted); see also Predicting Dismuption, supra note 119, at 227 (noting that "[r]esearch consistently indicates that adoption disruptions increase with the child's age at placement").

165 W. FEIGELMAN \& A. SilverMaN, supra note 119 , at 93 . 
al care, transracial placement is clearly the option more conducive to the welfare of the child.

If policy makers and social workers fail to consider [transracial adoption] as a possibility for homeless nonwhite children, then they are likely to condemn those who cannot be placed in black homes to significant and lasting psychological harm. ${ }^{166}$

These studies provide powerful evidence that the delays in placement and denials of permanent adoptive homes that are a part of current inrace placement policies are seriously harmful to children.

In the context of a society struggling with the issue of how to deal with racial difference, the studies of transracial adoptive families are extraordinarily interesting. They do not simply show that black children do well in white adoptive homes. They do not simply show that we put black children at risk by delaying or denying placement while we await black homes. The studies show that black children raised in white homes are comfortable with their blackness and also uniquely comfortable in dealing with whites. In addition, the studies show that transracial adoption has an interesting impact on the racial attitudes of the white members of these families. The parents tend to describe their lives as significantly changed and enriched by the experience of becoming an interracial family. They describe themselves as having developed a new awareness of racial issues. ${ }^{167}$ The white children in transracial adoptive families are described as committed to and protective of their black brothers and sisters. The white as well as the black children are described as exhibiting an unusual absence of white racial bias, ${ }^{168}$ and as unusually committed to the vision of a

${ }^{166}$ Id. at 100, 120. For a more detailed description of Feigelman and Silverman's findings, see id. at 98-100, 116-20; see also Predicting Dismuption, supra note 119, at 227 (concluding that age at placement was related to adoption disruption, but race difference between parent and child was not); R. BARTH \& M. BERRY, supra note 128, at 78, 118, 216 (concluding that "the evidence of adoption's considerable benefits must be weighed against the unknown implications of undemonstrated identity confusion. It is past time that adoption agencies incorporate these findings in their policies and practices and give transracial adoption a fresh look.").

${ }^{167}$ See R. Simon \& H. ALTSTEIN, TRANSRACIAL ADOPTEES, supra note 11, at 34 .

168 See id. at 27-28, 112-13; supra note 144 and accompanying text. 
pluralistic, multicolored world in which a person's humanity is more important than his race. ${ }^{169}$

The studies show parents and children, brothers and sisters, relating to each other in these transracial families as if race was no barrier to love and commitment. They show the black adopted and the white birth children growing up with the sense that race should not be a barrier in their relationships with people in the larger social context. In a society torn by racial conflict, these studies show human beings transcending racial difference.

\section{THE LAW ${ }^{170}$}

Current racial matching policies are in conflict with the basic law of the land on race discrimination. And they are anomalous. In no other area do state and state-licensed decisionmakers use race so systematically as the basis for action. In no other area do they promote the use of race so openly. Indeed, in most areas of our community life, race is an absolutely impermissible basis for classification.

The federal constitution, state constitutions, and a mass of federal, state, and local laws, prohibit discrimination on the basis of race by public entities. Private entities with significant power over our lives are also generally bound by laws prohibiting discrimination on the basis of race. In the past twenty-five years this body of law has grown so that today there are guarantees against race discrimination not only in housing, employment, and public accommodations, but in virtually every area of our community life.

It is true that the anti-discrimination norm has been limited by the principles of respect for privacy and freedom of association. People are permitted to act on the basis of racial preference in 82.

${ }^{169}$ See R. Simon \& H. ALTSTEIN, TRANSRACIAL ADOPTEES, supra note 11 , at 65,80 -

${ }^{170}$ For law review commentary on the issues addressed in this article, see generally Bowen, Cultural Convergences and Divergences: The Nexus Between Putative Afro-American Family Values and the Best Interests of the Child, $26 \mathrm{~J}$. FAM. LAW 487 (1987-88); Grossman, A Child of a: Different Color: Race as a Factor in Adoption and Custody Proceedings, 17 Buffalo L. REv. 303 (1968); Howard, Transracial Adoption: Analysis of the Best Interests Standard, 59 NOTRE DAME L. REv. 503 (1984); O'Brien, Race in Adoption Proceedings: The Pernicious Factor, 21 TULSA L.J. 485 (1986); Perry, supra note 17; Note, Constitutional Law: Race as a Factor in Interracial Adoptions, 32 CATH. U.L. REV. 1022 (1983) [hereinafter Note, Race as a Factor]; Note, Transracial Adoption: A Critical View of the Courts' Present Standards, 28 J. FAM. L. 303 (1989-90) [hereinafter Note, Transracial Adoption]; Note, supra note 163. 
choosing their friends and companions, and in forming truly private social clubs. Small employers and rooming houses were exempted from the employment and the housing provisions of the 1964 Civil Rights Act partly on the basis of these principles. ${ }^{171}$ But the state is not permitted to insist that race count as a factor in the ordering of people's most private lives. And so in Loving $v$. Virginia ${ }^{172}$ the Supreme Court held it unconstitutional for the state to prohibit interracial marriage, and in Palmore v. Sidoti ${ }^{173}$ the Court held it unconstitutional for the state to use race as the basis for deciding which of two biological parents should have custody of a child. Palmore involved the issue of whether a white child could be removed from the custody of its biological mother on the basis of the mother's relationship with a black man. The Court unanimously held that in this context reliance on race as a decisionmaking factor violated the equal protection clause of the fourteenth amendment. ${ }^{174}$ The Court rejected arguments that removal of the child from a racially mixed household was justified by the state's goal of making custody decisions on the basis of the best interests of the child. Conceding that there was a "risk that a child living with a stepparent of a different race may be subject to a variety of pressures and stresses not present if the child were living with parents of the same racial or ethnic origin," the Court nonetheless had no problem concluding that these were constitutionally impermissible considerations. ${ }^{175}$

The anti-discrimination principle has been interpreted to outlaw almost all race-conscious action by the state and by the agencies which control our community lives. There need be no showing that the action is designed to harm or that it results in harm. Raceconscious action has generally been allowed only where it can be justified on the grounds of compelling necessity, or where it is designed to benefit racial minority groups either by avoiding or preventing discrimination ${ }^{176}$ or by remedying its effects, as in the

${ }^{171}$ See 42 U.S.C. $\$ 2000 \mathrm{e}$ (b) (1988); id. § 2000a (b)(1).

172388 U.S. 1 (1967). The Court held that Virginia's ban on interracial marriage constituted a racial classification in violation of the equal protection clause as well as a denial of liberty without due process of law under the fourteenth amendment.

173466 U.S. 429 (1984).

${ }^{174}$ See id. at 494 . The Court noted that a core purpose of the fourteenth amendment was "to do away with all governmentally imposed discrimination based on race" and that "classifying persons by race is more likely to reflect racial prejudice than legitimate public concerns ...."Id.

175 Id. at 433.

${ }^{176}$ See, e.g., United Jewish Orgs. v. Carey, 430 U.S. 144 (1979) (upholding 
case of affirmative action. But these exceptions have been narrowly defined. ${ }^{177}$

The necessity doctrine was used to justify the exclusion for national security reasons of Japanese-Americans from military areas in this country during World War II. But it is a sign of how limited this doctrine is that the Supreme Court decision upholding this exclusion as constitutional ${ }^{178}$ stands essentially alone in our constitutional jurisprudence and has been significantly discredited. ${ }^{179}$

Affirmative action has always been controversial in this country. ${ }^{180}$ The anti-discrimination norm has generally been expressed in individualistic and race-neutral terms-forbidding discrimination "on the basis of race" or mandating "the equal protection of the laws"-and has accordingly been interpreted to protect whites as well as blacks. Action designed to promote black group interests has often been challenged as discriminatory against whites. The courts have generally insisted that for affirmative action programs to be upheld as legitimate they must be justified on the basis of a remedial rationale. ${ }^{181}$

In recent years the Supreme Court has held that for federal law purposes, even "benign" racial classifications are highly suspect and must be limited to narrowly defined situations. ${ }^{182}$ In City of Richmond v. J.A. Croson Company ${ }^{183}$ the Court held that state and local programs designed to benefit minority groups are subject to the same kind of strict constitutional scrutiny as programs designed to burden such groups. It held further that affirmative action can be justified as constitutional only if shown to be absolutely essential to remedying prior discrimination. ${ }^{184}$

consideration of race in legislative reapportionment on grounds that it was designed to avoid abridging right to vote on the basis of race).

177 See L. TRIBE, AMERICAN CONSTITUTIONAL LAW 1466 \& n.4 (2d ed. 1988).

178 See Korematsu v. United States, 323 U.S. 214 (1944).

179 See L. TRIBE, supra note 177 , at 1466.

180 See id. at 1523.

181 See id. at 1537-44.

182 See City of Richmond v. J.A. Croson Co., 488 U.S. 469 (1989); Johnson v. Transportation Agency, 480 U.S. 616 (1987); United States v. Paradise, 480 U.S. 149 (1987); Local 28, Sheet Metal Workers Int'l Ass'n v. Equal Employment Opportunity Comm'n, 478 U.S. 421 (1986); Wyggant v. Jackson Bd. of Educ., 476 U.S. 267 (1986). 183488 U.S. 469 (1989).

184 The Supreme Court held in 1990 that the United States Congress had greater leeway than the states to mandate affirmative action, in the only case in which the Court has specifically endorsed a non-remedial form of affirmative action. See Metro Broadcasting v. F.C.C., 110 S. Ct. 2997, 3009 (1990) (holding that congressionally- 
The adoption world is an anomaly in this legal universe in which race-conscious action is deemed highly suspect and generally illegal. In agency adoptions, as we have seen, race-conscious action is one of the major rules of the child allocation game. The fact that race is a recognizable factor in decisionmaking is enough under our general anti-discrimination norm to make out a case of intentional discrimination. ${ }^{185}$ Adoption agency policies make race not merely a factor, but the overwhelmingly significant factor in the placement process. ${ }^{186}$

The public adoption agencies, as well as many of the private agencies, are governed by legislative and constitutional provisions forbidding race discrimination. The Federal Constitution's equal protection clause, and the related Croson limit on legitimate affirmative action, apply to all state and local governmental entities, whether they be adoption agencies, adoption courts, or governmental bodies promulgating legislation, regulations, and other policies governing adoption. ${ }^{187}$ Title VI of the 1964 Civil Rights $\mathrm{Act}^{188}$

mandated affirmative action measures are not subject to "strict scrutiny" review, but will be upheld if "they serve important governmental objectives within the power of Congress and are substantially related to achievement of those objectives").

185 See infra note 218 and accompanying text.

${ }^{186}$ See supra Part III.

187 They may apply as well to at least some "private" adoption agencies. Recent Supreme Court decisions make clear that private entities are governed by the equal protection clause only under very limited circumstances, namely, where they function as the equivalent of a public entity. The fact that a private agency is licensed, funded, or regulated by the state or that it serves a traditionally public function has been held not sufficient to satisfy the state action requirement. See Blum v. Yaretsky, 457 U.S. 991 (1982) (limiting the state action doctrine); Rendell-Baker v. Kohn, 457 U.S. 830 (1982) (same); Moose Lodge No. 107 v. Irvis, 407 U.S. 163 (1972) (same). The Court, however, has simultaneously made clear that where formally private entities act pursuant to the state's "rule of conduct" or the state's "significant encouragements, either overt or covert," state action might be found. Blum, 457 U.S. at 1004. Private adoption agencies are, to a significant degree, following state-imposed directions when they pursue racial matching policies. States often have written or unwritten policies that mandate racial matching. State and federal government entities often - use their regulatory power, or their funding power, or their power to administer subsidy and recruitment programs to ensure that private agencies conform to samerace placement policies. See, e.g., McLaughlin v. Pernsley, 693 F. Supp. 318, 321-22 (E.D. Pa.), affd 876 F.2d 308 (3d Cir. 1989) (noting that a "private" agency moved black foster child from white to black foster home pursuant to public agency policy and pressure and holding that plaintiffs were entitled to an injunction under the equal protection clause). In addition, the Court has recognized that where a private agency performed functions that were "traditionally the exclusive prerogative of the State," its action would be deemed state action. See Blum, 457 U.S. at 1005. Certain aspects of adoption, including the legal formation of the adoptive family, have traditionally been the exclusive prerogative of the state.

188 Pub. L. No. 88-352, 78 Stat. 252 (codified as amended at 42 U.S.C. $\$ 2000 \mathrm{~d}$ 
bans discrimination by adoption agencies, public and private, that receive federal funds. Accordingly, it applies to virtually all public and many private agencies. ${ }^{189}$ Many states have constitutional, statutory, and regulatory provisions that broadly prohibit discrimination by public and private agencies.

But for some reason the anti-discrimination principle is thought to mean something quite different in the adoption area than it means elsewhere. The federal policy guidelines clarifying Title VI's meaning in the context of adoption and foster care ${ }^{190}$ are symptomatic of how differently the anti-discrimination norm is understood in this context. The guidelines provide specifically that race can be used as a basis for decisionmaking in foster and adoptive placement so long as it is not used in any absolute or categorical way to prohibit consideration of transracial adoption altogether. ${ }^{191}$ They state: "Generally, under Title VI, race, color, or national origin may not be used as a basis for providing benefits or services. However, in placing a child in an adoptive or foster home it may be appropriate to consider race, color, or national origin as one of several factors." 192 The guidelines go on to emphasize that this exception applies only in these contexts: "This policy is based on unique aspects of the relationship between a child and his or her adoptive or foster parents. It should not be construed as applicable

(1988)) ("No person in the United States shall, on the ground of race, color, or national origin, be excluded from participation in, be denied the benefits of, or be subjected to discrimination under any program or activity receiving Federal financial assistance.").

189 Virtually all public adoption agencies receive federal funds. Many private adoption agencies are covered by Title VI either by virtue of their contracts with public agencies or because of direct receipt of federal funding. See Telephone interview with Frank Weil, Office for Civil Rights, U.S. Department of Health and Human Services (Sept. 13, 1990).

Title VI may incorporate the Croson equal protection standard. In Regents of the Univ. of California v. Bakke, 438 U.S. 265 (1978), five Justices found the Title VI antidiscrimination mandate identical to the equal protection mandate.

${ }^{190}$ See Memorandum from David Chavkin, Deputy Director for Program Development, U.S. Department of Health and Human Services to Virginia Apodoca, Region X Director of the Office for Civil Rights (Jan. 19, 1981) (discussing "policy clarification" regarding "Race, Color, or National Origin as consideration in Adoption and Foster Care Placements") (on file with author).

191 The Chavkin memorandum reads "[r]ecipients are prohibited from categorically refusing to place children with adoptive or foster parents of another race, color, or national origin, from applying placement policies and criteria that are based exclusively on race, color, or national origin. ... Id. at 1 (emphasis added).

192 Id. 
to any other situation in the child welfare or human services area covered by Title VI. ${ }^{n 193}$

The racial matching policies fit none of the recognized exceptions to the anti-discrimination norm. There is no compelling necessity for racial matching, on a level comparable to a national emergency threatening the survival of the nation. The black community within this nation is not threatened with extinction. The number of black children available for adoption is very small compared to the size of the black community; ${ }^{194}$ placing more of those available for adoption transracially poses no realistic threat to the existence of that community or the preservation of its culture. It is hard to see transracial adoption as more threatening to these interests than racial intermarriage ${ }^{195}$ or racial integration in public education. Official efforts to prevent such intermarriage ${ }^{196}$ or to prevent black children from attending school with white children or being taught by white teachers ${ }^{197}$ have been held unconstitutional, and would be regarded as intolerable by blacks and whites alike in today's society.

Nor can racial matching policies be rationalized as programs designed to eliminate or to remedy the effects of prior discrimination, or otherwise to benefit blacks as a group. It is easy to argue that there has been such discrimination. Traditional agency screening procedures and criteria can be criticized as having discriminated against prospective black parents, depriving them of an equal opportunity to adopt. ${ }^{198}$ Transracial adoption, which

193 Id. at 4.

194 The Voluntary Cooperative Information Systems data indicate that there were 6100 black children legally free for adoption in 1987 and 7400 legally free for adoption in 1989. Roughly twice the number of children legally free for adoption have adoption as a designated "goal." See Telephone interview with Dr. Toshio Tatara, Director of Research and Demonstration, American Public Welfare Association (March 20,1991). One estimate indicates that by the end of 1977, a total of 15,000 black children had been adopted by whites. See D. DAY, supra note 11, at 89. The total black population of the United States is estimated at $\mathbf{3 0}$ million. See U.S. DEP'T OF COMMERCE, STATISTICAL ABSTRACT OF THE UNITED STATES 1990, at 12 (1990).

${ }^{195}$ Census figures indicate that there are approximately 177,000 black-white marriages in the United States, but this is probably a low estimate. See BUREAU OF THE CENSUS, CuRRENT Population REPORTS, SERIES P-20, No. 424, HouseHold AND FAMILY CHARACTERISTICS: MARCH 1987, at 94 (1988). The number of interracial marriages has been increasing at a significant rate. See U.S. DEPT. OF COMMERCE, BuREAU OF THE CENSUS, STATISTICAL ABSTRACT OF THE U.S. 1980, at 44 (1986).

196 See Loving v. Virginia, 388 U.S. 1 (1967).

197 See Brown v. Board of Educ., 347 U.S. 483 (1954).

${ }^{198}$ See D. DAY, supra note 11, at 99; see also supra note 92 and accompanying text. 
has operated to place black children but not white children across racial lines, can be criticized as having discriminated against the black children, depriving them of an equal opportunity to the benefits of a same-race upbringing. And transracial adoption can be seen as part of a continuing pattern of discrimination against the black community. A vast array of social policies going back to the institution of slavery can be characterized as responsible for the fact that it is black families whose children are disproportionately available for adoption and white families who are disproportionately in a position to seek adoption. Taking all these perspectives together, transracial adoption can be characterized, and indeed has been by the NABSW and others, as one of the ultimate forms of exploitation by whites of the black community and the black family. This understanding of the social and historical context gives meaning to the NABSW's description of transracial adoption as a form of racial genocide. The NABSW's goal of preventing transracial adoption and its current emphasis on efforts to preserve or reconstitute the biologic family as an alternative to adoption, can thus be understood as based on remedial justifications in at least some broad sense.

The problem is that racial matching policies do not look like the kinds of remedial affirmative action programs that the courts have accepted as legitimate. The policies are blatantly inconsistent with the Supreme Court's recent Croson decision which places severe limits on legitimate affirmative action, requiring a near-exact fit between a given affirmative action program and the discriminatory actions it is designed to remedy. Croson prohibits the use of affirmative action that is designed more broadly to counter the effects of historical or societal discrimination. ${ }^{199}$ But even apart from Croson, the courts have generally insisted that affirmative action programs look backward more than they look forward, be limited in duration, and be designed to help move society to a point where race can be eliminated as a decisionmaking factor. ${ }^{200}$ By

Blacks in this country are less likely as a group than whites to satisfy traditional screening criteria with respect to economic status, job security, marriage, and other factors, and blacks may also be less likely as a group to volunteer to submit to the extensive adoption process traditionally administered by agencies.

${ }^{199}$ I find the Croson holding enormously problematic and inconsistent with the purpose of the fourteenth amendment and with much of the development of the meaning of the amendment over the years. Croson, however, is quite clearly binding on the public adoption agencies and other public entities, subjecting their racial matching policies to strict scrutiny review.

${ }^{200}$ See generally supra notes $180-83$ and accompanying text. The Supreme Court's 
contrast, racial matching policies seem to look forward at least as much as they look backward. They require race matching on an ongoing basis, without apparent limit in time. They are not designed to eliminate the role of race in agency decisionmaking in the future, but to perpetuate its importance.

Racial matching policies are in addition fundamentally inconsistent with traditional affirmative action rationales because racial matching promotes racial separatism rather than racial integration. Black leaders in the adoption world originally promoted racial matching in the historical context of the black nationalism movement that gained prominence in the latter part of the 1960 s, with its calls for black power and black self-determination. Black leaders have argued for racial matching policies on the grounds that black people have the right to control the destiny of "their" children and that racial matching promotes the integrity of the black community and black culture. This is part of why so many of the studies of transracial adoptees have focused on the issue of racial identity as a measure of adoptive success. White leaders in the adoption world developed their policies of matching parents with adoptive children who were biologic look-alikes in a historical context in which racial intermarriage was universally frowned upon and often illegal. Racial matching policies serve to prevent racial integration in the intimate context of the family. By contrast, affirmative action programs that have had any general level of acceptance have been consistent with the orthodox view in this country on the nature of the racial problem and of appropriate solutions to that problem. That orthodox view holds that the problem lies in the segregation of an oppressed class, and the solution can be found in the integration of that class with those who have enjoyed the privileges of life in this society. Both anti-discrimination law and affirmative action programs have been designed to break down segregatory barriers and to promote integration.

recent decision in Metro Broadcasting, Inc. v. F.C.C., 110 S. Ct. 2997 (1990), stands as an important but nonetheless very limited exception to these general principles. It held that Congress can legitimately mandate race-conscious measures designed to benefit minority-owned businesses in the broadcast industry, where the purpose was to enhance programming diversity in the future, not simply to remedy discrimination against minority broadcasters in the past. See id. at 3009-10. Two Justices had previously indicated support for certain forward-looking forms of affirmative action. See Regents of the Univ. of California v. Bakke, 438 U.S. 265, 310-15 (1978) (Powell, J.); Wygant v. Jackson Bd. of Educ., 476 U.S. 267, 313 (Stevens, J., dissenting). 
Many would argue that the problem of race has more to do with oppression and racial hierarchy than with separation. They would see the solution, either short-term or long-term, in black separatism and black self-determination. Many would argue that the preservation and promotion of a separate black culture and black community serves important interests independent of overcoming social stratification. But these views have not been incorporated in the basic law of the land on race. ${ }^{201}$

In addition, and even more significant, race-conscious action that has any level of principled support in today's world relies on arguments that it benefits racial minorities. Even those courts and Supreme Court Justices most sympathetic to affirmative action have argued that allegedly benign racial classifications should be scrutinized carefully to ensure that they are truly benign in impact and do not serve to disadvantage their supposed beneficiaries. ${ }^{202}$ Racial matching policies are not clearly beneficial in any short-term or long-term sense to blacks as a group, and in fact, they seem quite harmful to a significant part of that group-the children in need of adoptive homes.

Thus, it is hard to understand racial matching policies as an affirmative action program clesigned for the benefit of black parents as a group. Anecdotal eviclence indicates that black birth parents who feel they have a choice among agencies often choose to surrender their children to private rather than public agencies, precisely because many of the private agencies have a reputation for putting a high priority on placing children without delay in whatever loving families are available, rather than delaying placement for same-race matching or other purposes. ${ }^{203}$ For prospective black adoptive parents, racial matching policies represent a complex mix

${ }^{201}$ See generally Peller, Race Consciousness, 1990 DURE L.J. 758 (describing the rejection and "marginalization" of black nationalist ideology in the 1970s and 1980s).

${ }^{202}$ See, e.g., Bakke, 438 U.S. at 361 (Brennan, J.) (arguing for "strict and searching review" of affirmative action because of the "significant risk that racial classifications established for ostensibly benign purposes can be misused, causing effects not unlike those created by invidious classifications"); United Jewish Orgs. v. Carey, 430 U.S. 144, 172-74 (1977) (Brennan, J., concurring in part) (" $[\mathrm{A}]$ purportedly preferential race assignment may in fact disguise a policy that perpetuates disadvantageous treatment of the plan's supposed beneficiaries. . . . [Therefore, the Court must give] careful consideration [to] the operation of any racial device, even one cloaked in preferential garb").

203 Birth parents whose children are in the custody of the state substitute care system generally are not asked their views on whether a same-race family should be sought for their child and have no ability to limit the state's race-matching priorities. 
of burdens and benefits. It is true that blacks who are interested in adopting get priority consideration for black children. But the policies operate to limit black as well as white prospective parents to color-matched children. Light skinned blacks may be limited to light skinned black children, dark skinned blacks to dark skinned black children, and interracial couples to those biracial children that are left over after same-race couples have been served. All of the above will almost certainly be precluded from consideration for a white child. It is also hard to see black parents as seriously victimized by virtue of any exclusion from the formal adoption process since there is no evidence of a large, unmet demand by black parents for more adopted children, as there is, for example, for better jobs, housing, or schools. Many of the children available for adoption are older children with complicated histories of abuse and neglect or children with serious mental and physical handicaps. It is difficult to place these children even when traditional parental screening criteria are scrapped and affirmative efforts are made to recruit black parents and to subsidize the adoptions. The parents who adopt these children may experience their parenting as a special privilege. But the fact is that our society conceives of the parenting of special needs children as involving very significant financial and emotional burdens. ${ }^{204}$

204 The subsidy aspect of the racial matching system could be seen as a form of benefit program for black parents. As indicated supra notes 85-90 and accompanying text, subsidies are generally made available to help prospective parents adopt samerace "special needs" children. A disproportionate number of the special needs children are black, both because in many states blackness itself qualifies a child for special needs status, as it does under federal law, and because blacks make up such a large percentage of the foster care pool, which itself is largely made up of children who by virtue of age or disability qualify for special needs status. The racial matching policies therefore mean that a large share of the special needs adoption subsidies are going to black parents. These policies also serve to channel a disproportionate share of foster care payments to the black community, by encouraging the use of same-race foster care as a long-term solution for children for whom no same-race adoptive home is available. See supra note 59. The payments involved are often on a level that is not insignificant for people living on or near the poverty level. See supra notes 89 \& 117. Current recruitment policies mean that we are reaching out to those living on welfare and other marginal incomes to find same-race parents.

But adoption subsidy and foster payment programs have not been conceived of as forms of welfare benefit programs. The rationale for these kinds of payments is that we want to enable people who are interested in parenting to do so. It is a very different thing to use these payments to raise the income level of people who have no particular interest in parenting but will agree to do so for a fee. To the degree that the adoption subsidy and foster care payment programs have in fact become financial benefit programs, they raise very troubling questions from the viewpoint of children. 
Racial matching policies make no more sense as affirmative action programs if we focus on the larger black community rather than just the parents. There is no particular reason to believe that blacks as a group would support these policies. They are policies developed and promoted by the leaders of one black social workers organization in the absence of any evidence of general support in the black community and with limited vocal support from any other organization. ${ }^{205}$ Reported surveys of black community attitudes indicate substantial support for transracial adoption and very limited support for the NABSW position or for the kinds of powerful matching principles embodied in today's adoption policies. ${ }^{206}$ The underlying motivations for these policies seem quite clearly to include a complex mix, with white opposition to race mixing in the context of the family playing a part. There is no obvious answer to the question whether racial matching policies are likely to benefit or burden the black community, advance or impede

205 The original NABSW position was a leadership position developed at a national conference workshop. See R. SIMON \& H. ALTSTEIN, TRANSRACIAL ADOPTION II, supra note 11 , at 63 .

The NABSW has never polled its membership or any larger black community to determine what level of support exists for the position. See Telephone interview with Leora Neal, Executive Director of New York Chapter of Association of Black Social Workers Child Adoption and Counselling and Referral Service (Jan. 29, 1991).

${ }^{206}$ For example, a study designed to assess the black community's attitudes regarding the transracial adoption debate found significant support for transracial adoption and very limited support for the NABSW's position among a sample black population. See Howard, Royse \& Skerl, Transracial Adoption: The Black Community Perspective, 22 SOC. WORK 184 (1977). A majority (56.7\%) had an "open" attitude toward transracial adoptions, while $6.7 \%$ were "most unfavorable" and $19.3 \%$ "somewhat unfavorable". See id. at 185-86. Three-fourths of all respondents felt transracial adoption might be beneficial if no black home was available, while only $16 \%$ disagreed. Eighty-one percent preferred transracial adoption over keeping a child in a foster home or institution, while $14 \%$ did not. See id. In looking at rationales, the study concluded: "While the respondents were concerned about the child's possible loss of identification with the black community, the needs of the individual child were seen to be of prime importance." Id. at 188.

An earlier study involved interviews with blacks and whites with some awareness of issues related to the placement of black children. The group included adoptive parents, adoption professionals, and black community representatives. The black respondents divided evenly for and against transracial placements. In general, persons with direct experience with transracial adoption came out two to one in favor of it. See Herzog, Sudia \& Harwood, Some Opinions on Finding Families For Black Children, 18 CHILDREN 143, 146 (19'1).

A third study asked a sample of "educated middle-class blacks" the general question of whether they approved of the practice of whites adopting black children and found opinion divided, with slightly under half (45\%) approving of the practice. See Simon, Black Attitudes Toward Transtacial Adoption, 39 PHYLON 135, 140 (1978). 
black group interests. It is certainly questionable whether imposing on the black community an obligation to take care of "its own," while providing limited resources for the job, does much to help that community.

What does seem clear is that current policies are harmful to the group of black children in need of homes. Affirmative action is not supposed to do concrete harm to one group of blacks in the interest of promoting what are at best hypothetical benefits to another. ${ }^{207}$

And adoption is not supposed to be about parent or community rights and interests, but rather about serving the best interests of children. Adoption laws throughout this country provide that agencies are to make children's interests paramount in placement decisions. Arguments can be made that black children in general will benefit from efforts to strengthen the black community, and that racial matching policies represent one such effort. The problem is that as indicated above, ${ }^{208}$ racial matching policies seem contrary to the immediate and long-term interests of the specific black children waiting for homes.

Advocates for racial matching of course argue that growing up with same-race parents is a benefit of overriding importance to black children. But the claim that a black person, by virtue of his or her race, will necessarily be more capable than a white of parenting a black child is the kind of claim that courts have generally refused to allow as justification for race-conscious action. ${ }^{209}$ The near-absolute presumption under our anti-discrim-

207 See United States v. Starrett City Assocs., 840 F.2d 1096 (2d Cir. 1988). At issue was the use of racial quotas that limited black access to a housing complex in the interest of maintaining racial integration. The case thus involved a conflict between blacks interested in living in adequate and integrated housing and blacks interested in gaining access to that housing. The court struck down the accesslimiting quotas as inconsistent with the Fair Housing Act's anti-discrimination mandate, relying on the Supreme Court's affirmative action cases, discussed supra note 202. Affirmative action has always been limited by the principle that benefits to a group shall not be provided at undue cost to innocent individuals, although the cases in which the Supreme Court has asserted this principle have generally involved affirmative action programs designed to benefit blacks as a group at the alleged expense of whites. See Wygant v. Jackson Bd. of Educ., 476 U.S. 267 (1986) (holding that the extension of preferential protection against layoffs to minority teachers at the expense of non-minority teachers violated the fourteenth amendment). See generally supra notes 180-82 and accompanying text.

${ }^{208}$ See supra Parts IV \& V.

${ }^{209}$ Again, the Supreme Court's decision in Metro Broadcasting, Inc. v. FCC, 110 S. Ct. 2997 (1990), stands as an important but limited exception to this principle. In upholding a preference for minority-owned businesses in the broadcast industry, a 5-4 majority of the Court indicated some acceptance, for the first time, of the idea that 
ination laws is that race is irrelevant to qualifications. Moreover, the available evidence does not support the claim that same-race placement is beneficial to black children, much less that it outweighs the harm of delayed placement. ${ }^{210}$ Ultimately, the argument that racial matching policies are beneficial rather than harmful to the children immediately affected rests on the unsupported assumption that black children will be significantly better off with "their own kind." This may or may not be true; empirical studies involving human beings and the attempt to measure human well-being may not be capable of proving the proposition one way or another. But it is not the kind of assumption that has been permitted under our nation's anti-discrimination laws. More importantly, it is not an assumption that should be permitted in a situation where there is evidence that by insisting on a racial match we are doing serious injury to black children.

If racial matching policies are as inconsistent with the law of the land on race as $I$ have argued they are, it is interesting that they have been allowed to exist. There seems to be an extraordinary level of agreement among policy-makers that whatever the law provides with respect to race in other contexts, it is appropriate to use race as a basis for decisionmaking in the context of the adoptive family. Courts have both failed to confront the issues involved in racial matching policies, ${ }^{211}$ and have shown significant sympathy for those policies.

race might be intrinsically related to qualifications-here the ability to promote diversity in programming. See id. at 3011 . But as noted previously, the significance of this case is limited by the fact that since congressional action was involved, the Court applied a uniquely lenient standard of constitutional review. In previous cases dealing with action by state entities, the Supreme Court has never been willing to endorse "role model" or other non-remedial rationales for affirmative action. For example, in Wygant, the Court was presented with an affirmative action program involving the hiring of school teachers, where the goal for minority hiring had been set with a view toward providing minority children in the school system with a roughly proportionate number of same-race teachers. See Wygant, 476 U.S. at 270. The Court struck down the plan for a variety of different reasons, with four Justices indicating they felt that the goal of providing students with same-race teachers was not a constitutionally appropriate one. See id. at 275-76.

210 See supra Part V.

211 This is in part because litigants have rarely forced the issues upon the courts by bringing cases in which the goal is to challenge and reform the operation of an adoption agency's entire system of racial matching and in which the proof is likely to present the court with evidence as to the real nature and extent of the policies. Instead, the court cases challenging agency practices with respect to race have generally been individual cases brought by whites denied the opportunity to parent a particular black child, with the goal of reversing the particular agency decision at 
The courts have generally agreed upon a legal doctrine that race cannot be used by agencies as the sole or automatically dispositive factor in placement decisionmaking, ${ }^{212}$ but can be used as a significant and even determinative factor. ${ }^{213}$ Some courts actually require that race be considered. ${ }^{214}$

issue. See infra notes 212-14.

212 See, e.g., McLaughlin v. Pernsley, 693 F. Supp. 318, 324 (E.D. Pa. 1988), affd on other grounds, 876 F.2d 308 (3d Cir. 1989) (holding that black child's removal from white foster parents solely on the basis of race violated the equal protection clause); In re Adoption of a Minor, 228 F.2d 446, 448 (D.C. Cir. 1955) (noting that although race may be relevant, "that factor alone cannot be decisive in determining the child's welfare”); Compos v. McKeithen, 341 F. Supp. 264, 266 (E.D. La. 1972) (striking down Louisiana law limiting adoption to same-race placements, holding that while race can be legitimately considered a "relevant" factor, it cannot be "the determinative factor"); In re Davis, $502 \mathrm{~Pa}$. 110, 130, 465 A.2d 614, 624 (1983) (noting that race "cannot be unduly emphasized . . . by the placement agency" (emphasis omitted)); In re Adoption of Gomez, 424 S.W.2d 656, 659 (Tex. Civ. App. 1967) (striking down Texas law prohibiting transracial adoption); In re Adoption of Baker, 117 Ohio App. 26, 28, 185 N.E.2d 51, 53 (1962) (noting that although under ordinary circumstances a child should be placed with parents of the same race, "a [different] placement is not precluded").

213 See Drummond v. Fulton County, 563 F.2d 1200, 1205 (5th Cir. 1977)(en banc), cert. denied, 432 U.S. 905 (1978) (upholding the constitutionality of adoption agency action where race was a decisive factor); In re R.M.G. \& E.M.G., 454 A.2d 776 (D.C. 1982) (upholding a District of Columbia statute authorizing consideration of race in adoption proceedings and finding that race can be used as the "determinative" factor so long as it is not used so as to favor automatically the inracial over the transracial placement); In re D.I.S. for Adoption of S.A.U., 494 A.2d 1316, 1327 (D.C. App. 1985) (finding equal protection clause strict scrutiny standard inapplicable, upholding use of race as a factor in placement, and relying on fact that statute did not require race be considered, but simply required that information regarding race be supplied); In re Davis, 502 Pa. 110, 127, 129, 465 A.2d 614, 622, 624 (1983) (noting that case precedent overwhelmingly adopts the position that race should be a factor, and so holding).

The court-approved settlement in a major challenge to race matching policies talks of the "constitutionally permissible use of race-conscious criteria" in foster and adoptive placement, specifies that a child shall not be removed from foster care "solely" on the basis of race difference, and provides that race "must" be taken into account so that same-race adoptive placement may be preferred. See Committee to End Racism in Michigan's Child Care Sys. v. Mansour, No. 85CV743DT, at 1-3 (E.D. Mich. Jan. 13, 1986) (consent decree) (on file with author). Interestingly, this decree is seen as a significant victory by critics of current racial matching policies, because it was designed to limit the more absolutist racial matching policies of the Michigan Child Welfare System. See id. See also National Committee to End Racism in America's Child Care System, The Children's Voice Newsletter (Jan.-Mar. 1989) (reporting on a Voluntary Compliance Plan agreed to by the Office for Civil Liberties of the United States Department of Health and Human Services (the agency responsible for enforcing Title VI of the 1964 Civil Rights Act against adoption agencies) that permits Washington state to "consider" race in placement decisions but bars its use as a basis for categorically prohibiting all transracial placements). See generally Note, Race as a Factor, supra note 170, at 1025 .

214 See Drummond, 563 F.2d at 1205-06 (stating the agency has "responsibility" to 
A major problem with the factual analysis in these adoption cases is that the courts tend to ignore ${ }^{215}$ or distort ${ }^{216}$ the systemic role race plays in agency decisionmaking. The cases portray a world in which the general practice is consistent with the courts' current legal doctrine that race shall not function in an absolute or automatic way in placement decisions. The courts act as if their role in these cases is to determine whether the agency decision in the case before them represents a transgression of the generally understood rules of the game-an aberration from an agreed upon norm of behavior. They are either unaware, or unwilling to acknowledge, that adoption agencies throughout the country are operating under rules that regularly make race a central and determinative factor in placement decisions. ${ }^{217}$

A major problem with the courts' legal doctrine in these adoption cases is that it is inconsistent with the way courts define the nature of unlawful discrimination in areas other than adoption. In other areas the anti-discrimination norm forbids decisionmakers from giving race any role in their decisionmaking processes. If a party is able to show that race has played a part in arriving at the decision at issue, that decision is presumptively unlawful. ${ }^{218}$ The

consider race); In re B. Children, 89 Misc. 2d 498, 496-97, 391 N.Y.S.2d 812, 813-14 (N.Y. Fam. Ct. 1977) (reversing social services decision leaving child with white foster parent and stating that "we must also consider the interracial aspects" of the case); In re Davis, 502 Pa. 110, 126, 465 A.2d 614, 622 (1983) (holding it error for trial court to fail to consider racial factor).

215 See, e.g., Child v. Beame, 425 F. Supp. 194 (S.D.N.Y. 1977) (challenging New York City's systematic failure to provide black children with permanent homes, where the court accepts without questioning the City Department of Social Services' policy of looking only to black families for homes for these children).

${ }^{216}$ See, e.g., Drummond, $563 \mathrm{~F} .2 \mathrm{~d}$ at 1204-11. In this case, the court upheld an agency decision refusing to allow a white couple to adopt a biracial child who had lived with them for two years, although there was no black adoptive family available, and the white family had previously been described as providing excellent care. The facts laid out in the Fifth Circuit's panel opinion, Drummond v. Fulton County, 547 F.2d 835, 837-49 (5th Cir. 1977), together with an understanding of how matching policies generally work, indicate that the dissenting judges in the en banc opinion were correct in concluding that race was the determinative and indeed the only factor at issue. See Drummond, 563 F.2d at 1219; see also Rockefeller v. Nickerson, 36 Misc. 2d $869,870,233$ N.Y.S. 2d 314, 315-16 (1962) (denying white family application for adoption despite the absence of any alternative adoptive home for black foster child and refusing to inquire into role racial matching policies played in agency decision). See generally Note, Transtacial Adoption, supra note 170, at 314-15.

217 See supra Part III.

218 The standard is "but for" causation. In cases where race is one of a number of factors contributing to a decision, the Supreme Court has placed the burden on the decisionmakers to demonstrate that they would have come to the same result on 
judges have come up with little justification for treating the racial issue so differently in the adoption context. Some judges have relied on unsubstantiated claims that the evidence from the adoption world indicates that black children will necessarily risk serious identity and other problems if they are raised by whites. ${ }^{219}$ Some have relied on their own assumptions regarding such problems. ${ }^{220}$ Others have expressed what seems to be at the heart of much judicial thinking in this area-the sense that mixing the races in the context of the family is simply not "natural." In one leading case, the majority opinion states: "It is a natural thing for children to be raised by parents of their same ethnic background". 221 The opinion speaks approvingly of traditional matching policies as designed to duplicate the "natural biological environment" so that the child could develop a "normal family relationship. ${ }^{222}$

This sense that what is "natural" and "normal" in the intimate context of family are same-race relationships is at the heart of the law on transracial adoption. But in Loving $v$. Virginia, ${ }^{223}$ the Supreme Court rejected similar thinking in striking down Virginia's miscegenation statute. The trial court had reasoned as follows:

the basis of non-racial factors. See Price Waterhouse v. Hopkins, 490 U.S. 228 (1989); Mt. Healthy City Bd. of Educ. v. Doyle, 429 U.S. 274 (1977).

219 See, e.g., Drummond, 563 F.2d at 1205 (claiming that the professional literature regarding transracial placement supports consideration of race to avoid "the potentially tragic possibility of placing a child in a home with parents who will not be able to cope with the child's problems"); see also In re R.M.G. \& E.M.G., 454 A.2d at 787,792 (D.C. 1982) (relying on a highly selective and misleading description of the literature). Judge Newman, in his dissenting opinion in In re R.M.G. argues for a legal standard that more clearly vindicates the use of race as a factor in placement. See id. at 796-810. Judge Newman dismisses the significance of the extensive body of positive evidence regarding the adjustment of transracial adoptees, and he relies instead on a selective reading of the negative views on transracial adoption, together with the fact that adoption professionals generally favor racial matching. Id.; see also In re Davis, $502 \mathrm{~Pa}$. at 125-33, $465 \mathrm{~A} .2 \mathrm{~d}$ at $622-24$ (upholding the use of race in foster placement decision, and relying on speculative claims by the NABSW and others regarding the alleged problems transracial placements might involve); In re $B$. Children, 89 Misc. 2d at 497, 391 N.Y.S.2d at 814 (reversing a social services decision leaving a black child with its white foster mother and characterizing as a "penetrating study" speculative argumentation in an article by an early and well-known critic of transracial adoption).

220 See, e.g., In re B. Children, 89 Misc. 2d at 497, 391 N.Y.S.2d at 814 (stating that "this child's self-image and acceptance of his Black identity are crucial to his adjustment in life and his place in the world").

221 Drummond, 563 F.2d at 1205.

222 Id.

223388 U.S. 1 (1967). 
Almighty God created the races white, black, yellow, malay and red, and he placed them on separate continents. And but for the interference with his arrangement there would be no cause for such marriages. The fact that he separated the races shows that he did not intend for the races to mix. ${ }^{224}$

The Supreme Court reversed, holding racial classifications embodied in Virginia's "Racial Integrity Act" unconstitutional, "even assuming an even-handed state purpose to protect the 'integrity' of all races. ${ }^{225}$

Legislatures and executive policy-makers, like the courts, generally have taken a hands-off attitude towards adoption agency policies with respect to race where they have not affirmatively intervened to mandate or permit the use of race as a criterion in adoption placement. ${ }^{226}$

One reason for the general tolerance of racial matching policies may be the fact that they have a direct impact on a relatively small and powerless group consisting of minority children without homes and the whites interested in parenting them. When white employees are denied seniority rights or job promotions in favor of minorities, this is experienced as a threat to significant economic interests by large portions of the population, and unions and other powerful organizations are galvanized into action to protect against the threat. The sight of older and disabled black children being held in foster care rather than placed with whites, or taken from whites to be placed with blacks, simply does not trigger the same kind of concern in the larger white community. Consequently, no

224 Id. at 3 (quoting from trial judge's unpublished opinion).

225 Loving, 388 U.S. at $12 \&$ n.11. The Court refused to consider "scientific" arguments against the wisdom of interracial marriage, finding the racial classification presumptively unconstitutional. See id. at 8 . There has been a dispute about the potential identity and self-esteem problems of the children of interracial marriage similar to that regarding transracial adoptees. See Perry, supra note 17, at 70-71, 90 nn. 136-38.

${ }^{226}$ See supra notes 65-68 \& 190-93 and accompanying text. However, a few states have passed legislation making it illegal to deny adoption solely on the basis of race. See OHIO ADMIN. CODE § 5101:2-48-03 (1990) (stating that cultural heritage may be a factor for consideration, but race shall not be sole criterion, and adoption shall not be delayed because of failure to find matching family); MD. FAM. LAW CODE ANN. $\$ 5.311$ (1990) (declaring that agency director cannot withhold consent to adoption solely on basis of race); WIS. STAT. ANN. $\$ 48.82(6)$ (West 1990) (forbidding denial of adoption "because of" race); CONN. GEN. STAT. ANN. § 45-63 (West Supp. 1990) (providing that an adoption cannot be denied solely because of a difference in race); KY. REV. STAT. ANN. \$199.471 (Baldwin 1976) (providing that an adoption cannot be denied because of adopting parents' race, unless the biological parents object). 
major power organizations step forward to join ranks with white prospective parents to mount a campaign against the racial matching policies. For the black and liberal white organizations that have traditionally focused on the welfare of children, racial matching policies pose complicated political issues. ${ }^{227}$ It is black adoption workers who have most vocally promoted the policies and who have condemned transracial adoption as a form of white racism.

Another reason for this general tolerance is presumably the existence of widely held views that black children should be raised by black parents if this is at all possible. Professionals involved in adoption issues agree with near-unanimity on this proposition. ${ }^{228}$ Even those most active in criticizing what they see as the excesses of current racial matching policies tend to concede that transracial adoption should be considered only if there is no viable inracial placement available. Almost no one advocates the elimination of any preference whatsoever for inrace placement-that is, the creation of the kind of race-blind regime typically considered the ideal to be achieved in other areas of social life.

*****

The remaining issue is what to do about the discrepancy between our nation's general laws on racial discrimination and the adoption world's matching policies. It should be clear that the powerful preference for same-race placement embodied in many of today's policies violates guarantees against discrimination contained in Title VI of the 1964 Civil Rights Act and in the Constitution. The evidence that these policies are doing harm to the group of

227 Although the National Committee For Adoption has criticized practices that result in delays in or denial of placement, its criticisms have been muted and limited and it has not mounted a major campaign to effect change, as it has in other areas of adoption law. The only organization that has publicly taken up the cause of reforming racial matching policies is the National Coalition to End Racism in America's Child Care System, a small and relatively powerless organization started by white foster parents. The Coalition publishes a newsletter, encourages prospective adoptive parents to bring to court cases in which they have been adversely affected by racial matching policies, helps them in those efforts, and promotes administrative and legislative change. It has sometimes been assisted in these efforts by the American Civil Liberties Union.

${ }^{228}$ For two among many examples of the professional endorsement of the matching principle, see STANDARDS FOR ADOPTION SERVICE, discussed supra text accompanying notes 69-70, and the National Committee for Adoption's policy position, discussed supra text accompanying note 71 . 
black children waiting for homes precludes any affirmative action justification. But it is not quite so clear how the law should view the issue of whether race should be entirely precluded from consideration in adoptive placement. The issue cannot be seen as entirely determined by law; it presents a choice for those who make and interpret the law. Legislatures and courts are continually redefining the nature of the anti-discrimination norm and of permissible affirmative action. Current legal limitations on affirmative action programs are far too restrictive, in my view, in their concern for the protection of white rights, ${ }^{229}$ and their demand for a close fit between the design of an affirmative action program and a limited remedial goal. ${ }^{230}$ Adoption puts the state, or state-licensed agencies, in the position of structuring the uniquely private relationship involved in a family. The Supreme Court cases dealing with state barriers to interracial marriage ${ }^{231}$ and with state use of race as a basis for deciding custody between biological parents ${ }^{232}$ deal with similar issues. These cases suggest strongly that the state should stay out of the business of promoting same-race families in the context of adoption. No exact legal analogue in Supreme Court jurisprudence exists, however, for the adoption issue. ${ }^{233}$ We need

${ }^{229}$ See supra notes $180-84,199$ and accompanying text.

${ }^{230}$ See, e.g., Sullivan, The Supreine Courh 1985 Term: Comment: Sins of Discrimination: Last Term's Affirmative Action Cases, 100 HARv. L. REv. 78 (1986) (critiquing the Court's narrow conception of affirmative action).

231 See Loving v. Virginia, 388 U.S. 1 (1967).

232 See Palmore v. Sidoti, 466 U.S. 429 (1984).

233 The situation involved in Palmore does present a close analogue, however. In deciding a custody dispute, the state is deciding how to structure a family, and in Palmore, the Court held that race could not be used as the basis for the custody decision. However, in Palmore there was no potential for arguing that the policy at issue benefitted the black community, since a white father was seeking removal of a white child because the mother had developed a relationship with a black man. In addition, the Court characterized the issue as involving the custody rights of a "natural mother." Palmore, 466 U.S. at 430, 434. A number of courts and commentators have drawn a distinction between the use of race in a custody dispute involving biological parents, and its use in a dispute involving the alleged parenting rights of foster or adoptive parents. See, e.g., In re Davis, 502 Pa. 110, 117, 465 A.2d 614,622 ( $\mathrm{Pa} .1983$ ) (discussing the importance of race in the two different situations); Farmer v. Farmer, 109 Misc. 2d 13'7, 439 N.Y.S.2d 584, 588-89 (N.Y. App. Div. 1981) (finding appropriate the fact that race plays a more decisive role in custody disputes involving "non-parents"). See generally Perry, supra note 17, at 5-11 \& n.17 (stating that there is "no agreement on the relevance of Palmore to adoption and foster care"). Although this distinction is not at all persuasive for me, it is consistent with the bias in our law of honoring biological parent ties over any interest in becoming an adoptive parent or maintaining foster parent relationships. See, e.g., Smith v. Org. of Foster Families, 431 U.S. 816 (1977) (noting the tendency to honor biological 
to think about what policies are appropriate in the adoption context. If policies embodying some limited preference for samerace placement seem the right ones, then it is our race law that needs to be changed, or adapted to accommodate them.

\section{DIRECTIONS FOR THE FUTURE}

Racial matching should not be seen as an issue on which black interests are pitted against white interests, with blacks on one side fighting for the rights of "their children" supported by whites sympathetic to the black community, and opposed by white parents who want the children for their own benefit and by defenders of white privilege.

As indicated above, there is no evidence of significant black support for current racial matching policies, ${ }^{234}$ and there is reason to think that if fully informed about the nature of these policies and their impact on black children, many blacks would oppose them. And it is clear that these policies are harmful to those blacks most affected-the children in need of homes.

White support and tolerance for racial matching policies should not be seen as necessarily benign. It may well be that liberal white guilt helps explain why white adoption workers joined ranks with the NABSW to close down transracial adoption. But something else is going on here as well. One would expect good liberals to worry more about the apparent interests of the black children waiting in foster care in finding the best possible homes at the soonest possible time. If these white social workers were reserving for blacks jobs or other benefits prized by the white community, they would clearly meet a great deal of resistance. Given the impact these policies have on black children, it is hard to understand them as an expression of white community concern to advance the interests of black people. It would appear instead that the white

parenting and providing limited protection to foster parenting ties). Palmore also fails to make entirely clear whether in a biological parent custody dispute, race is absolutely precluded from consideration, or whether the case is limited to the holding that race cannot be the sole basis for decisionmaking. See Perry, supra note 17, at 1011 \& n.17, 19-23. Cf. Holt v. Chenault, 722 S.W.2d 897 (Ky. 1987) (holding that child's actual emotional reaction to biological parent's relationship with other-race parent, if significant and severe, can be considered in a decision regarding custody change); J.H.H. \& S.C.H. v. O'Hara, 878 F.2d 240 (8th Cir. 1989) (distinguishing Palmore and upholding use of race as a factor in foster placement in case where child might eventually return to biological parent), cert. denied, 110 S. Ct. 1117 (1990).

234 See supra notes 205-06 and accompanying text. 
community just does not care that much about the fate of black children who wait for homes. And the notion that the black community has a right to hold onto "its own" is likely to strike a sympathetic chord among whites who would feel uncomfortable at the idea of a white child being raised in a black or biracial family.

The issues at the heart of current racial matching policies are the significance of racial difference and the role of racial separatism in dealing with difference. Historically, these policies represent the coming together of white segregationists with black nationalists and the merger of their racial separatist ideologies with "biologism". Adoption professionals have idealized the biological family and structured the adoptive family in its image. They have argued that biologic sameness helps make families work, and so have promoted the goal of matching adoptive parents with their biologic look-alikes. Although adoption professionals surrendered various aspects of their matching philosophy as they struggled to keep up with the realities of the adoption world, they held onto the core idea that racial look-alikes should be placed together. ${ }^{235}$ Even at the high point of the transracial adoption movement, placement across racial lines was seen more as a regrettable but necessary last resort, than as a positive good. ${ }^{236}$ The NABSW leadership's attack on transracial adoption met with relatively ready acceptance from white as well as black social workers, not just because of liberal white guilt, but because it fit with the traditional assumptions of their professional world. This adoption world is part of a larger social context in which there has always been a strong sense that racial differences matter deeply, and a related suspicion about crossing racial lines. Both black nationalists and white segregationists promote separatism, especially in the context of the family, as a way of promoting the power and cultural integrity of their own group. Even those blacks and whites generally committed to integration often see the family as the place to draw the line.

From a separatist perspective, current racial matching policies make a certain amount of sense, even if they do result in the denial of permanent adoptive homes to black children who could be placed. Those who believe in maintaining the separateness of the white community can take comfort from the fact that current policies provide a near absolute guarantee that white children will

235 See supra text accompanying note 15.

236 See supra text accompanying notes 26-27. 
not be placed with black parents or with interracial couples. They might see as disturbing, as do the NABSWA advocates, the evidence that the black children in these transracial adoptive families seem more likely than other black children to engage in inter-racial dating, and seem more open to the possibility of interracial marriage. ${ }^{237}$

Those who believe in promoting a sense of black community can take comfort in the fact that most of the black children who do not find adoptive homes are growing up in the black community, whether in traditional foster homes or in relatives' homes. They can also take comfort from the fact that the current system has created added pressure for preservation or reunification of the black biological family. They can see as irrelevant or even as deeply disturbing the evidence as to the apparent well-being of transracial adoptees. Thus, if one believes that black children should be an integral part of a functioning black community and should experience their black heritage and black culture as central to their being, then the evidence that black children are functioning as loving members of their white families and comfortable participants in their white social and educational communities would be problematic. The children's "adjustment" to this white world might well, from this perspective, be read as evidence of pathology, rather than psychological health. One might be prepared to assume that transracial adoptees will pay a heavy price for living in a community in which they will never "belong", whether or not they or their white parents are aware of their loss, and whether or not the studies are capable of measuring it. In any event, one might see some short term sacrifice of black children's interests as justifiable when weighed against the long-term interests of the larger black community. In this view, current policies might be seen as justified by virtue of the pressure they put on the white community to come up with the additional resources necessary to keep black children in their biological families or to place them with black families.

But one can recognize the importance of racial and cultural difference without subscribing to separatism. One can celebrate a child's racial identity without insisting that the child born with a particular racial make-up must live within a prescribed racial community. One can recognize that there are an endless variety of

237 See R. SIMON \& H. ALTSTEIN, TRANSRACIAL ADOPTEES, supra note 11, at 82; R. MCROY \& L. ZURCHER, supra note 121, at 68. 
ways individual members of various racial groups choose to define their identities and to define themselves in relationship to racial and other groups. One can believe that people are fully capable of loving those who are not biological and racial likes, but are "other," and that it is important that more learn to do so. One can see the elimination of racial hostilities as more important than the promotion of cultural difference.

From this perspective, which is one I share, transracial adoptive families constitute an interesting model of how we might better learn to live with one another in this society. These families can work only if there is appreciation of racial difference, and love that transcends such difference. And the evidence indicates that these families do work. Accordingly, I believe that current racial matching policies should be abandoned not simply because they violate the law but because they do serious injury to black children in the interest of promoting an inappropriate separatist agenda.

Assuming that the powerful matching policies of today were abandoned or outlawed, the question would remain as to what role, if any, race should play in the agency placement process. Most critics of today's policies focus their criticism on the degree to which race matching principles dominate the placement process, rather than on the fact that race is allowed to play any role at all. They tend to argue for a rule that would allow race to be used as a factor, but not an exclusive factor in decisionmaking, and for limits on the delay to which a child can be subjected while a same-race family is sought. ${ }^{238}$

In my view, adoption agencies should be prohibited from exercising any significant preference for same-race families. No delays in placement-whether for six months or one month-should be tolerated in the interest of ensuring a racial match. Delay harms children because, at the very least, it will cause discontinuity and disruption. And any delay risks further delay.

Accordingly, any preference for same-race placement that involves delay or that otherwise threatens the interest of the children involved in receiving good homes should be viewed as unlawful racial discrimination, inconsistent not simply with traditional limits on affirmative action, ${ }^{239}$ but with any legitimate

${ }^{238}$ See National Committee for Adoption, Statement by the Executive Committee (Aug. 4, 1984), reprinted in ADOPTION FACTBOOK, supra note 5, at 157-59. This argument is discussed supra notes $71 \& 78$ and accompanying text.

239 See supra text accompanying notes 180-84, 194-210. 
concept of affirmative action. The courts and administrators responsible for interpreting and enforcing the law should apply established legal principles to find any such preference in violation of the equal protection clause of the Constitution, Title VI of The 1964 Civil Rights Act, and other applicable anti-discrimination mandates.

The only real question, then, is whether agencies should be allowed to exercise a genuinely mild preference. A mild preference would mean that if an agency had qualified black and white families waiting to adopt, it could take race into account in deciding how to allocate the children waiting for homes. The agency could operate on the principle that all things being essentially equal, it would be better to assign black children to black parents and white children to white parents.

There are some valid arguments in support of a mild preference. There is some reason to think that, all things being equal, same-race placements could serve children's interests. There is, for example, reason to fear that white parents might harbor racial attitudes, on a conscious or subconscious level, which would interfere with their ability to appreciate and celebrate their black child's racial self. One has only to step into the world of adoption to realize how widespread and powerful are the feelings among prospective adopters that race matters as they think about what child they will want to adopt. Indeed, the adoption world is largely peopled by prospective white parents in search of white children. The urgency of their race-conscious quest seems to explain much about that world. 240 But the picture is a complicated one. There is tremendous variation among adoptive parents in their racial attitudes. And their attitudes are shaped and conditioned by messages they receive from adoption workers and the broader society, as well as by the adoption process. Many white adopters look to adopt black American or dark-skinned foreign children as their preferred option. ${ }^{241}$ Many others begin their adoption quest with the thought of a white child and later turn to transracial adoption after considering their options. For them transracial adoption may appear to be a "second choice." But the fact is that for a very large number of adoptive parents adoption itself is a second choice or

240 See supra text following note 4.

241 See, e.g., D. DAY, supra note 11, at 93-94 (noting that a mix of idealistic and other motivations is involved in the decision to adopt transracially); C. ZASTROW, supra note 128, at 81 (same). 
"last resort." Many adoptive parents are infertile, and they turn to adoption only after discovering they cannot reproduce themselves biologically. It is understandable in this context that in adoption their first instinct would be to look for a biologic and racial lookalike. They are of course conditioned by current racial matching policies to think that they should do this. They are simultaneously conditioned by a variety of forces in our society to think of biological parenting as preferable to adoptive parenting. All adoptions require parents to transcend this kind of conditioning. The evidence indicates that adoptive parents are able to do so and that adoptive relationships work. ${ }^{242}$ The evidence similarly indicates that when whites arrive at the point of consciously choosing transracial parenthood and enter into parenting relationships with black children, the relationships work, and indeed, appear to work as well as same-race biologic parenting relationships. ${ }^{243}$

There is nonetheless some reason for concern that transracial adoption might add in a problematic way to the adopted child's sense of difference. It is difficult for children to be different from those they see as being in their group or world. All adopted children have to deal with the difference of having lost their biological parents. Many adoption professionals feel that this difference puts adoptees at risk of feeling that they do not really belong. One question is whether we want to add to the sense of difference by placing black adoptees with white parents in what are likely to be significantly white communities. We may believe that these children should feel they truly belong; research studies provide some evidence that they do. But it still seems likely that

242 Unsupported negative clairns abound regarding the characteristics associated with adoptive status. See ADOPTION FACTBOOK, sispra note 5, at 205-06 (exploring the "[m]yth of the "Adopted Child Syndrome"). The controlled studies designed to assess the impact of adoptive status itself (as opposed to factors such as early deprivation, abuse, or disability) on the parent-child relationship and the adjustment of adoptees reveal no evidence that adoptive status has a negative impact on successful functioning. In fact, there is some evidence that it has a positive impact. See L. STEIN \& J. HOOPES, IDENTITY FORMATION IN THE ADOPTED ADOLESCENT 33-34, 46 (1985); Marquis \& Detweiler, Does Adopted Mean Different? An Attributional Analysis, 48 J. PERsonalITY \& Soc. Psychology 1051, 1054-66 (1985). But see Brodzinsky, Schechter, Braff \& Singer, Psychological and Academic Adjustment, 52 J. CoNsulTING \& CLINICAL PSYCHOLOGY 582, 588 (1984) (noting that controlled sample of adoptees displayed slightly more extreme forms of behavior than non-adopted children). See generally C. Santor, The Biological Link and Its Effect on Adoption as a Viable Family Alternative 1-4, 12-34 (1990) (unpublished paper on file with author).

${ }^{243}$ See supra Part V. 
many children would find it more comfortable, all things being truly equal, to be raised by same-race parents. ${ }^{244}$

A mild preference for same-race placement might also seem to serve the interests of black adults who want to parent, as well as the kind of black community interests discussed above. It would counter, at least to some degree, the tendency of transracial adoption to work only in one racial direction. ${ }^{245}$ This tendency has been, understandably, a piece of what critics of transracial adoption have found most offensive.

But there would be real dangers in a rule involving even a mild preference. On a symbolic level, it is problematic for the state to mandate or even tolerate a regime in which social agencies, rather than private individuals, decide what shall be the appropriate racial composition of families. It is similarly problematic for the state to decide what the "appropriate" racial identity for a child is and how it is best nurtured. The Supreme Court decided some time ago that the state should not be in the business of deciding whether interracial marriages are wise. Indeed, we would not want to live in a regime in which social agencies prevented such marriages, or prevented interracial couples from producing children. Transracial adoption is, of course, different from interracial marriage in that it involves minor children, many of whom are unable to express their own desires with respect to the kind of family they would like. But it seems dangerous for the state or its agencies to assert that children should not or would not choose to ignore race if they could exercise choice in the formation of their families, and to

${ }^{244}$ Ken Watson, the Director of the Chicago Child Care Society, presents a version of this argument:

It is hard to rear a child born to one. To rear a child in adoption is more difficult. Parenting a child of a different race is more complicated still; and for a caucasian family to parent a black child in this country is yet again more complicated. If an agency tries to place children in families in which they, and their adoptive families, will encounter the fewest complications, how can it not take into consideration race as a major factor?

Letter from Ken Watson to Elizabeth Bartholet (Jan. 18, 1990).

245 It is true that if agencies were precluded from considering race at all, white children could be assigned to black parents, as they are not today. But most black and white prospective parents are likely to continue to choose same-race children to the extent such children are available. And the numbers mismatch, described supra notes 61-63 and accompanying text, is likely to continue. There will be more black children waiting than there are prospective black families and many waiting white families eager to adopt black children. 
conclude that it is presumptively in the child's best interest to have a same-race upbringing.

Moreover, the existence of transracial adoptive families in which blacks and whites live in a state of mutual love and commitment, and struggle in this context to understand issues of racial and cultural difference seems a positive good to be celebrated. The state should not be in the position of discouraging the creation of such families. ${ }^{246}$

On a pragmatic level, there is a real question as to whether it is possible to create a genuinely mild preference for same-race placement-a real danger that if any racial preference is allowed, enormous weight will in fact be given to race no matter what the formal rule of law. After all, agencies and courts commonly describe today's matching policies as if race functioned simply as one of many factors in decisionmaking, with nothing more than a mild preference for inrace placement at work. Current adoption law, as reflected in court rulings ${ }^{247}$ and the administrative guidelines $^{248}$ interpreting Title VI, is that race should not be used in the absolute and determinative way that we know it systematically is used. Given the extraordinary level of commitment by adoption professionals to inrace placement and the amount of discretion they have traditionally enjoyed to make placement decisions, it may well be that the only practicable way to prevent race from playing the kind of determinative role that it plays today is to prohibit its use as a factor altogether.

On balance then, it seems that even a mild preference is unwise as a matter of social policy. The generally applicable legal rule that race should not be allowed to play any role in social decisionmaking should be held to apply in the adoption area as well. Policy-makers should not treat such a preference as an appropriate form of affirmative action. ${ }^{249}$

${ }^{246}$ In addition, while I have been talking about a preference for same-race placement of black children, it is hard to imagine agreement upon a rule that would apply only to black children. But policies requiring a preference for same-race matching of white children would be extremely hard to justify constitutionally.

247 See supra text accompanying note 212.

248 See supra notes $190-93$ and accompanying text.

249 This is not to say that a mild preference for same-race placement should necessarily be seen as violative of the equal protection clause. It would be difficult to reconcile such a preference with the current Supreme Court view of the scope of legitimate affirmative action, since it could not be justified as a narrowly targeted program designed to further a specific and limited remedial goal. See supra notes 182-83 \& 199 and accompanying text. But a mild preference for the same-race 
Black and white prospective parents should be free to adopt children without regard to any adoption agency worker's views as to which children are an appropriate race match. Agencies should use subsidies and other recruitment devices to reach out to prospective parents of all races to find homes for the children who cannot be placed without such recruitment. Agencies should revise traditional criteria for white as well as black prospective parents, with the goal of creating a pool of people interested in and capable of providing good homes for all the children in need.

A no-preference regime would remove adoption agencies from the business of promoting same-race placement. It would not mean that racial considerations must be ignored altogether in the agency process. Agencies could act in their educational and counselling capacity to advise prospective parents with respect to racial matters. They could encourage parents to explore their feelings with respect to race, and they could try to educate parents as to issues involved in raising a child of a different race. They could try to guide prospective parents in the direction of the children they seem most fit to raise. But neither agencies nor courts should, as some have suggested, ${ }^{250}$ use their decisionmaking powers to approve pro-

placement of black children could be justified under the more generous interpretation of the scope of legitimate affirmative action that seems to me appropriate-one which focused primarily on the issue of whether the program was apparently benign, in intent and effect, with respect to the interests of an oppressed minority group. See supra note 202 and accompanying text.

${ }^{250}$ In the consent decree discussed supra note 213, the Michigan Department of Social Services was required to develop an assessment tool to be used in determining whether a family could qualify to adopt or foster a child of a different race. The assessment was to be designed to determine "the capacity, ability and disposition of a family to appreciate and educate a child of a different race regarding the child's racial, ethnic and cultural heritage and background." Committee To End Racism in Michigan's Child Care Sys. v. Mansour, No. 85CV743DT, at 9 (E.D. Mich. Jan. 13, 1986).

In McLaughlin v. Pernsley, 693 F. Supp. 318 (E.D. Pa. 1988), affd, 876 F.2d 308 (3d Cir. 1989), the court held that removal of a black child from its foster family solely on the basis of race violated the Constitution, but stated that a court must nonetheless determine whether whites can adequately provide for a black child's racial and cultural needs. The court observed:

A part of this examination would involve an inquiry into whether a prospective couple could instill and foster in a child a positive sense of racial identity. Other factors such as whether prospective foster parents live in an integrated neighborhood or would send their foster child to an integrated school, etc., should also be examined.

693 F. Supp. at 324 n.6; see also Court Sets Terms for Whites Adopting Black, N.Y. Times, Aug. 10, 1990, at A13, col.5 (reporting that a Hamilton County court referee ordered a white family to undergo counseling and education on black culture as a condition 
spective parents as parentally fit, to match parents with a particular child, or to prescribe and enforce rules as to appropriate attitudes regarding a child's racial identity or the manner in which a child of another race should be raised. It is important for agencies to try to help parents think through what they should do to affirm their child's racial identity. But it is dangerous for the state to be in the business of mandating how people should think about their child's racial heritage, and for the state to establish requirements regarding who they should have as friends, where they should go to church, and where they should live.

Agencies could and should allow prospective parents and children old enough to express their views to decide what role race should play in the adoption process. ${ }^{251}$ In the adoption area the state is attempting to create a human relationship that is as intimate, as powerful, and as permanent as any that human beings know. It is as if the state were plunged by necessity into the business of arranging marriages. It is wrong for the state to presume that a racial match is central to the happiness of every coupled parent and child. But it is equally wrong for the state to insist on arranging parent-child couplings without regard to the racial feelings of the people involved.

\section{CONCLUSION}

Establishment of a regime in which there is no official preference for same-race placement seems the wise course and the direction in which we should move. But it is a proposal that will meet a good deal of resistance in many quarters. It should be possible, however, to achieve substantial agreement on the importance of moving promptly to eliminate the kinds of racial matching policies that exist today.

Both common sense and the available evidence from empirical studies indicate that racial matching policies are doing serious harm to black children. Accordingly, these policies violate the principle

for being allowed to adopt their black foster child to enable them to "help her develop her black identity"); D. DAY, supra note 11, at 113 (discussing race-related screening criteria that have been suggested for prospective transracial adopters); $\mathbf{R}$. MCROY \& L. ZURCHER, supra note 121, at 70 (same).

${ }^{251}$ Birth parents have been largely excluded from the placement decision in the traditional agency process, but they have played an increasingly active role of late in many private agencies as well as in some of the public agencies. A discussion of the role birth parents should play in the placement decision is beyond the scope of this Article. 
at the core of our nation's adoption laws, namely that the best interest of the child should govern the placement process. They also violate the anti-discrimination norm contained in the nation's various civil rights laws and in the equal protection clause of the Constitution.

The evidence from the empirical studies indicates uniformly that transracial adoptees do as well on measures of psychological and social adjustment as black children raised inracially in relatively similar socio-economic circumstances. The evidence also indicates that transracial adoptees develop comparably strong senses of black identity. They see themselves as black and they think well of blackness. The difference is that they feel more comfortable with the white community than blacks raised inracially. This evidence provides no basis for concluding that there are inherent costs in transracial placement from the children's viewpoint.

By contrast, the evidence from the empirical studies, together with professional opinion over the decades and our common sense, indicate that the placement delays of months and years that result from our current policies impose very serious costs on children. Children need permanency in their primary parenting relationships. They may be destroyed by delays when those delays involve, as they so often do, abuse or neglect in inadequate foster care or institutional situations. They will likely be hurt by delays in even the best of foster care situations, whether they develop powerful bonds with parents they must then lose, or they live their early years without experiencing the kind of bonding that is generally thought crucial to healthy development.

Current policies also significantly increase the risk that minority children who are older and who suffer serious disabilities will never become part of a permanent family. Advocates of these policies claim that prospective white parents do not want these children anyway. But the last two decades have demonstrated that efforts to educate and recruit adults of all races are successful in changing attitudes and making people aware of the satisfactions involved in parenting children with special needs. Current policies mean that virtually no such education and recruitment is going on in the white community with respect to the waiting minority children. These are the children who wait and wait. They represent a significant piece of the foster care problem. It defies reason to claim that we would not open up many homes to these children if agencies were willing to look for such homes in the white community. 
It is true, as advocates of current policies often say, that more could be done to find black families. More substantial subsidies could be provided and more resources could be devoted to recruitment. But it is extremely unlikely that our society will anytime soon devote more than lip service and limited resources to putting blacks in a social and economic position where they are capable of providing good homes for all the waiting black children. It will always be far easier to get white society to agree on the goal of placing black children in black homes than to get an allocation of financial resources that will make that goal workable. The danger in using black children as hostages to pry the money loose is that white society will not see these lives as warranting much in the way of ransom. Moreover, in a desperately overburdened and underfinanced welfare system, those who care about children should take children's many needs into account as they make decisions about allocating any new funds that might be available. Money is desperately needed to provide services that will enable biological families to function so that children are not unnecessarily removed from parents who could provide them with good parenting were it not for adverse circumstances. It is desperately needed to protect children from abuse and neglect. It is desperately needed to improve the adoption process so that children who should be permanently removed from their families are freed up for adoption and placed as promptly as possible with permanent adoptive families. Money is needed in these and other areas to help ensure some very basic protections for children that should take priority over the essentially adult agenda of promoting racial separation. 